
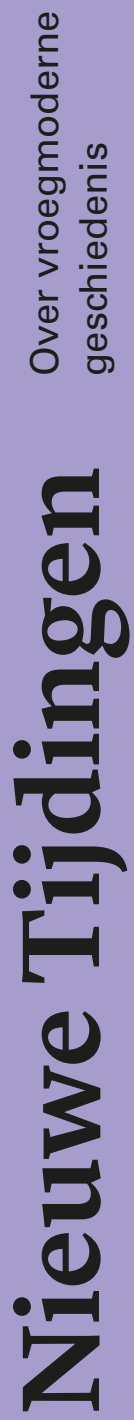

\title{
Vroegmoderne geschiedenis in actuele debatten
}

Jasper van der Steen \& Hans Cools (red.) 
Inhoud

5 Geschiedenis herschrijven

Over het belang van de vroegmoderne periode in hedendaagse

maatschappelijke debatten en de rol van historici daarbij

Jasper van der Steen en Hans Cools

17 Polderen en ploeteren

Een debat over geschiedenis, continuïteit en Nederlandse identiteit

Marjolein 't Hart

39 De herdenkingsbeweging en de plaats van het slavernijverleden in de Nederlandse identiteit

Karwan Fatah-Black

53 Spiegels van Sophia

Geleerdenportretten en de verbeelding van vrouwen als wetenschappelijke autoriteit: een historische kadering

Lieke van Deinsen

79 Het Plakkaat van Verlatinge (1581) in het Nederlandse herdenkingsjaar 2018

Historici versus dagbladpers

Anton van der Lem

95 In de voetsporen van de meesters

Rembrandt, Rubens en hun museumhuizen in Amsterdam en

Antwerpen

Hans Cools 
Nieuwe Tijdingen. Over vroegmoderne geschiedenis - 2020

Vroegmoderne geschiedenis in actuele debatten 


\title{
Nieuwe Tijdingen
}

Over vroegmoderne geschiedenis

Nieuwe Tijdingen. Over vroegmoderne geschiedenis neemt de lezer mee naar het vervlogen verleden van de vijftiende tot en met de achttiende eeuw. Iedere uitgave richt zich op een recente ontwikkeling in het historisch onderzoek naar deze schakelperiode. Daardoor komen verrassende thema's aan bod: van sacrale ruimte tot publieksgeschiedenis, van handelsnetwerken tot lobbypraktijken, van festiviteiten tot onderwijsinstellingen. Geïnteresseerden in de vroegmoderne tijd worden zo geprikkeld door toegankelijk geschreven bijdragen, terwijl vakgenoten in deze artikelen de laatste stand van het onderzoek kunnen consulteren. Alle artikelen zijn beoordeeld door anonieme referenten.

Nieuwe Tijdingen is een initiatief van de Vlaams-Nederlandse Vereniging voor Nieuwe Geschiedenis (VNVNG) en verschijnt vanaf 2017 bij Universitaire Pers Leuven.

\author{
Redactie \\ Anita Boele (Universiteit Utrecht) \\ Judith Brouwer (Huygens ING) \\ Hans Cools (KU Leuven) \\ Raingard Esser (Rijksuniversiteit Groningen) \\ Michael Limberger (Universiteit Gent) \\ Guido Marnef (Universiteit Antwerpen) \\ Dries Raeymaekers (Radboud Universiteit Nijmegen) \\ Wouter Ryckbosch (Vrije Universiteit Brussel) \\ Jasper van der Steen (Universiteit Leiden)
}

\author{
Adviesraad \\ Peter Arnade \\ Luc Duerloo \\ Craig Harline \\ Geert Janssen \\ Christine Kooi \\ Joop Koopmans \\ Judith Pollmann \\ Griet Vermeesch
}




\section{Vroegmoderne geschiedenis in actuele debatten}

onder redactie van Jasper van der Steen \& Hans Cools 
Verschijnt jaarlijks in oktober

Print ISSN: $2593-0346$

Online ISSN: $2593^{-0354}$

(C) 2020 Leuven University Press / Presses Universitaires de Louvain /

Universitaire Pers Leuven. Minderbroedersstraat 4, B-30oo Leuven (Belgium)

Alle rechten voorbehouden. Behoudens de uitdrukkelijk bij wet bepaalde uitzonderingen mag niets uit deze uitgave worden verveelvoudigd, opgeslagen in een geautomatiseerd gegevensbestand of openbaar gemaakt, op welke wijze ook, zonder de uitdrukkelijke voorafgaande schriftelijke toestemming van de uitgevers.

ISBN 9789462702608

e-ISBN 9789461663689

$\mathrm{D} / 2 \mathrm{O} 2 \mathrm{O} / 1869 / 53$

NUR: 685

DOI: https://doi.org/10.11116/9789461663689

Ontwerp: DOGMA

Illustratie omslag: Jan Lievens, Portret van Anna Maria van Schurman, 1649, The National Gallery, Londen 


\title{
Geschiedenis herschrijven
}

\author{
Over het belang van de vroegmoderne \\ periode in hedendaagse maatschappelijke \\ debatten en de rol van historici daarbij*
}

\author{
Jasper van der Steen en Hans Cools
}

D e rol van professionele historici is tweeledig. In de eerste plaats zijn geschiedkundigen geïnformeerde dragers van historische kennis. Door hun deskundigheid over een specifiek thema zijn ze bij uitstek geschikt om, als zo'n thema door hun of andermans toedoen in de publieke belangstelling komt, daarover hun licht te schijnen. In de tweede plaats zijn historici wetenschappers die juist de onzekerheden in historische kennis opzoeken, open vragen stellen aan het verleden en door onderzoek tot nieuwe inzichten komen. Die twee functies zijn soms moeilijk te combineren, zeker in concurrentie met auteurs van historische publicaties die niet als wetenschappers 'gehinderd' worden door de eisen van het vak. ${ }^{1}$ Terwijl de liefhebber met grote stelligheid een verhaal kan brengen, wordt het werk van historische wetenschappers juist gekenmerkt door een genuanceerde benadering, ruimte voor twijfel en scepsis. Deze spanning speelt in het bijzonder wanneer opinie- en beleidsmakers geschiedenis polemisch inzetten om er hun politieke argumenten mee te onderbouwen. Niet alleen contemporanisten worstelen met die spanning. Ook historici van de vroegmoderne Lage Landen dienen er zich toe te verhouden. Uit de Tachtigjarige Oorlog (1568-1648) zijn immers de staatkundige voorlopers van zowel Nederland als België

* Met dank aan Bart van der Steen voor het lezen van een eerdere versie van deze introductie.

1 Zie ook: M. MacMillan, The uses and abuses of history, London 2010. Een recent voorbeeld van dit fenomeen vormt het indrukwekkende publiekssucces van Bart Van Loo's, De Bourgondiërs, Amsterdam 2019. Cf. H. Cools, 'Een Huizinga voor de eenentwintigste eeuw. Bart Van Loo over de Bourgondiërs', in: Ons Erfdeel, 62.2 (2019), pp.133-134. 
voortgekomen. ${ }^{2}$ Bovendien voeren politici de veronderstelde Nederlandse tolerantie graag zo ver als mogelijk terug in de tijd en pretenderen zij dus dat die reeds één van de drijfveren van de Opstand zou zijn geweest. Daarbij gaan zij er gemakshalve aan voorbij dat de Opstand ook tot het historisch patrimonium van Vlaanderen behoort en dat de religieuze en politieke conflictstof die in de jaren 1560 tot ontploffing kwam goeddeels in grote zuidelijke steden zoals Antwerpen, Brussel en Gent opgestapeld lag. ${ }^{3}$ Die spanning tussen verleden en hedendaagse toe-eigening staat dan ook centraal in dit nummer van Nieuwe Tijdingen.

Een sleutelmoment uit de Opstand was de Beeldenstorm. Logischerwijze duiden verschillende groepen in de samenleving haar toen en nu op heel verschillende wijze. Hoewel aanvankelijk zelfs overtuigde calvinisten met een zekere schaamte op de evenementen uit de zomer en het najaar van 1566 terugkeken, hoort zij tegenwoordig zelfs voor de makers van de Canon van de Nederlandse geschiedenis bij de barensweeën van de natie. ${ }^{4}$ In de Zuidelijke Nederlanden zijn de sporen van de Beeldenstorm dan weer verdwenen onder het patina van de katholieke restauratie. Recentelijk hebben Judith Pollmann en Carolina Lenarduzzi er op gewezen dat relicten van iconoclasme voor katholieken in de Nederlandse Republiek daarentegen herinneringen

2 Cf. De titel van de tentoonstelling die van 12 oktober 2018 tot en met 20 januari 2019 in het Amsterdamse Rijksmuseum liep.8o jaar Oorlog. De geboorte van Nederland.

M. Reynebeau 'Het Pronkstuk walmt van het nationalisme', in: De Standaard, 31 januari 2018. Een dag later verscheen Reynebeau's aanklacht onder de lichtjes gewijzigde kop 'Het Pronkstuk van Nederland walmt van het nationalisme' ook in zusterkrant NRC Handelsblad. Zie verder: H. Cools, 'Waarom we het in 2018 weer over Willem van Oranje en het Wilhelmus hebben. De Nederlandse Opstand begon 450 jaar geleden', in: Ons Erfdeel, 61.1 (2018), pp.10-19.

J. Pollmann, 'Iconoclasts Anonymous: Why Did it take Historians so long to Identify the Image-Breakers of 1566?', in: Bijdragen en Mededelingen betreffende de Geschiedenis der Nederlanden, 131.1 (2016), pp.155-176, aldaar p.158 en H. Cools, 'De Beeldenstorm', in: H. Leeuwenberg, H. Slechte \& T. van Staalduine (red.), De Reformatie. Breuk in de Europese geschiedenis en cultuur, Zutphen 2017, p.169. De canon van Nederland fungeert als een richtsnoer voor het geschiedenisonderwijs op Nederlandse scholen. De eerste versie werd in 2006 voorgesteld. Op 20 juni 2020 presenteerde de Commissie 'Herijking Canon van Nederland' een vernieuwde versie voor. Bij die gelegenheid werd het oorspronkelijke venster 'De Beeldenstorm' ondergebracht in het nieuwe venster 'De Opstand'. 
aan een verloren tijd opriepen. ${ }^{5}$ Anne-Laure Van Bruaene, Koenraad Jonckheere en Ruben Suykerbuyk stellen op hun beurt dat iconoclasme fungeert als 'a breaker of cultural codes'. Voor ben biedt onderzoek naar de zestiende-eeuwse Beeldenstorm inzicht 'into what was at stake in the sixteenth-century Low Countries'. ${ }^{6}$ Dit zijn inzichten die we niet in de laatste plaats te danken hebben aan hedendaagse vormen van iconoclasme, zoals het religieus geïnspireerde geweld in de Syrische stad Palmyra, waar Islamitische Staat in 2015 cultureel erfgoed verwoestte.

Het al dan niet omstreden karakter van de verwijdering van beelden is afhankelijk van wat er precies op het spel staat. Dat zien we ook in de discussies rond koloniale beelden in de moderne tijd. De hedendaagse oproep van Black Lives Matter-actiegroepen tot verwijdering van koloniale standbeelden, zoals de beelden van koning Leopold II van België of het standbeeld van Jan Pieterszoon Coen in Hoorn, wordt even goed door velen veroordeeld als een poging tot het uitwissen van de nationale identiteit. ${ }^{7}$

Niet alle vormen van 'beeldenstorm' worden als zodanig herinnerd. Veranderingen die zich in stilte voltrekken, kunnen onomstreden blijven. Kort na de Tweede Wereldoorlog werd de Amsterdamse Amstellaan de Stalinlaan. Na de Sovjetinval in Hongarije in 1956 bleek Stalin echter toch niet zo'n lichtend voorbeeld en veranderde het gemeentebestuur de straatnaam opnieuw, ditmaal in Vrijheidslaan. Hoewel deze naamswijziging destijds omstreden was in communistische kringen, herinnert tegenwoordig vrijwel niets er nog aan. Dit staat in schril contrast met de publieke strijd rondom het beeld van Jan Pieterszoon Coen in Hoorn, de gouverneur-generaal van de VOC die duizenden doden op de Banda-eilanden op zijn geweten heeft. Publieke pleidooien voor en protesten tegen verwijdering van het beeld domineren de discussie, maar het standbeeld staat er nog altijd, weliswaar voorzien van een bordje met historische context (afb. 1).

5 J. Pollmann, 'Met grootvaders bloed bezegeld. Over religie en herinneringscultuur in de zeventiende-eeuwse Nederlanden', in: De Zeventiende Eeuw 29 (2013), pp.166-167; Idem, Memory in Early Modern Europ.15oo-180o, Oxford 2017, pp.54-55; C. Lenarduzzi, Katholiek in de Republiek. De belevingswereld van een religieuze minderheid 1570-1750, Nijmegen 2019, pp.91-142.

6 A.-L. Van Bruaene, K. Jonckheere \& R. Suykerbuyk, 'Introduction', in: BMGN 131.1 (2016), pp.3-14.

7 D. de Boer, 'Constructief beeldenstormen: lessen uit de zestiende eeuw', Over de muur, https://overdemuur.org/constructief-beeldenstormen-lessen-uit-de-zestiende-eeuw/ (geraadpleegd 20 augustus 202O). 


\section{FOKKE \& SUKKE \\ LOPEN OVER DE VRIJHEIDSLAAN}

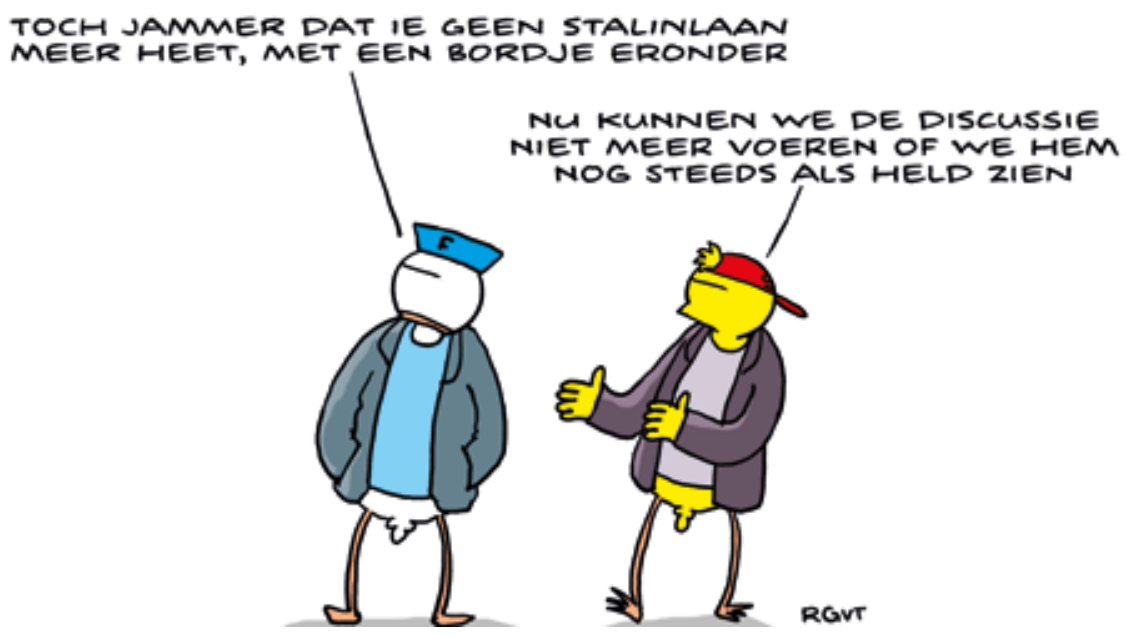

1. (c) Reid, Geleijnse \& Van Tol. Met dank aan de makers voor de toestemming voor dit hergebruik.

Nederlanders en Vlamingen hebben aanzienlijk minder moeite negentiende- en twintigste-eeuwse schurken van hun sokkel te trekken dan vroegmoderne lieden. Neem bijvoorbeeld de aanvankelijk relatief geruisloze verwijdering van een buste van Johan Maurits van Nassau-Siegen in het Mauritshuis in Den Haag. Vanwege de rol van Johan Maurits in de handel van tot slaaf gemaakten besloot het museumbestuur deze replica van kunststof (uit 1986) stilletjes te verwijderen en daarvoor in de plaats een achttiende-eeuws terracotta beeldje van de vorst te plaatsen in een zaal gewijd aan zijn leven. ${ }^{8}$ Ditmaal leidde zelfs een 'stille' verwijdering tot nationale beroering tot op het hoogste niveau: minister-president Mark Rutte liet weten dit 'een gekke stap' te vinden. ${ }^{9}$

8 C. Monteiro \& E. Odegard, 'Slavery at the Court of the 'Humanist Prince'. Reexamining Johan Maurits van Nassau-Siegen and his Role in Slavery, Slave Trade and Slave-smuggling in Dutch Brazil', in: Journal of Early American History 10.1 (2020), pp.3-32, aldaar p.7.

9 'Rutte had beter kunnen zwijgen in kwestie-Johan Maurits', in: NRC Handelsblad, 23 januari 2018 
Veranderende houdingen ten opzichte van (postkoloniale) ‘beeldenstormen' illustreren bij uitstek het voortdurende politieke belang dat het grote publiek toekent aan de vroegmoderne periode. Conflicten rondom nationale standbeelden richten zich immers vooral op de beelden van personen die geassocieerd worden met 'de geboorte' van een natie en in het geval van Nederland op een periode die aan de ene kant gezien wordt als Gouden Eeuw en aan de andere kant als het beginpunt van Nederlandse koloniale agressie. Beide fenomenen - beginnende natievorming en kolonialisme hebben hun wortels in de vroegmoderne tijd. Politici hebben daarom speciale belangstelling voor deze periode. De voormalige leider van de Socialistische Partij, Jan Marijnissen, ijverde sinds het begin van de een-en-twintigste eeuw voor de oprichting van een nationaal historisch museum met onder andere aandacht voor de Tachtigjarige Oorlog. ${ }^{10}$ Premier Jan Peter Balkenende vond in 2006 dat Nederlanders best wat trotser mochten zijn op de 'VOC-mentaliteit'. ${ }^{11}$ Recenter hebben ook populisten zich bediend van historische vergelijkingen. Geert Wilders ging in 2010 op de foto als zijn held Michiel de Ruyter en retweette dit beeld in 2016 met de boodschap: 'Nederland terugveroveren.' ${ }^{12}$ Thierry Baudet plaatste de laatste jaren zijn politieke partij met de reeks propagandistische geschiedenisfilmpjes 'De Gouden Eeuwen van Nederland' in een trotse lijn van historische vrijheidsstrijders, waarin Willem van Oranje overigens schittert in afwezigheid. ${ }^{13}$ Volgens andere partijen verdiende Willem van Oranje juist meer aandacht. Onder druk van het CDA werd het Wilhelmus opgenomen in het regeerakkoord van Rutte III, als een onderwerp waarover op scholen lesgegeven zou moeten worden. ${ }^{14}$ Overigens liet Mark Rutte, van opleiding een historicus, niet alleen van zich horen in de kwestie Johan Maurits. Ook toen activisten het paneel 'Hulde der Koloniën' van de Gouden Koets bekritiseerden merkte hij op: 'Het herschrijven van de

10 J. Marijnissen, Waar historie huis houdt, Amsterdam 2005, p.66.

11 Voortzetting van de algemene politieke beschouwingen naar aanleiding van de Miljoenennota voor het jaar 2007, Handelingen Tweede Kamer, 6-28o, https://zoek. officielebekendmakingen.nl/h-tk-20062007-272-294.html (geraadpleegd 11 augustus 2020).

12 Tweet van Geert Wilders, 9 augustus 2016, https://twitter.com/geertwilderspvv/ status/763113354357538821 (geraadpleegd 12 augustus 2020).

13 'De Gouden Eeuwen van Nederland' (2019), Youtubekanaal Forum voor Democratie, https://www.youtube.com/playlist?list=PLi7orMmZGePvYsERbrlKzJnbv-I2R4r6W (geraadpleegd 10 augustus 2020).

14 Cools, 'Waarom', pp.10-19. 
geschiedenis door de Gouden Koets te vernielen, daar ben ik niet voor'. ${ }^{15}$ Op vergelijkbare wijze reageerde de Nederlandse minister van Onderwijs, Cultuur en Wetenschap, Ingrid van Engelshoven, in 2019 kritisch op de beslissing van het Amsterdam Museum om de term 'Gouden Eeuw' te vervangen met 'Zeventiende Eeuw': 'Het is goed om alle kanten van de Nederlandse geschiedenis te belichten, maar de geschiedenis kan niet worden herschreven.' 16

In reactie op de opmerking van minister Van Engelshoven liet historicus Suze Zijlstra zich ontvallen: 'Je vraagt je af wat de minister denkt dat historici eigenlijk doen.' ${ }^{17}$ De angst voor het herschrijven van de geschiedenis komt niet uit het niets. Het verband met politieke propaganda in totalitaire staten is snel gelegd. Maar de critici die beweren dat we het verleden niet met de waarden van nu moeten beoordelen vergeten vaak dat juist professionele geschiedschrijving lange tijd eerst en vooral is ingezet, ook in liberale democratieën, om de natiestaat te legitimeren.

De discussies tussen voor- en tegenstanders van het herschrijven van de klassieke narratieven draaien in essentie dan ook om de vraag wie tot de natie behoort. Zo heeft Nederland, zoals hierboven reeds gememoreerd, sinds 2006 een van overheidswege gesanctioneerde historische canon. Die werd eertijds uitdrukkelijk opgezet met de bedoeling de integratie van 'nieuwkomers' te bevorderen. ${ }^{18}$ In Vlaanderen bepleitte Bart De Wever in zijn in 2019 gepubliceerde essay Over identiteit de invoering van een soortgelijk richtsnoer. ${ }^{19}$ Intussen heeft de Vlaamse regering in de persoon van de Leuvense historicus Emmanuel Gerard een voorzitter van haar canoncommissie aangeduid. Die moet in 2022 haar werkstuk afleveren. ${ }^{20}$ Dergelijke exercities kunnen echter alleen maar slagen als de doelgroepen een plaats in het verhaal van de natie krijgen. Zo ruimde de oorspronkelijke versie van de Nederlandse canon wel een

P. Ramesar, “Geschiedenis herschrijven door vernielen koets? Bizar”, in: Trouw, 17 september 2011.

16 'Minister: 'Geschiedenis Gouden Eeuw niet herschrijven', Het Parool, 13 september 2019. Overigens heeft Maarten Prak zeer recentelijk juist betoogd dat hoewel de term 'Zeventiende Eeuw' niet onproblematisch is, de voordelen toch opwegen tegen de nadelen. Cf. M. Prak, Nederlands Gouden Eeuw. Vrijheid en geldingsdrang, Amsterdam 2020.

17 Interview met Suze Zijlstra door S. de Knecht, ScienceGuide, 13 september 2019, https://www.scienceguide.nl/2019/o9/je-vraagt-je-af-wat-de-minister-denkt-dat-historici-eigenlijk-doen/ (geraadpleegd 10 augustus 202O).

18 Cf. H. Cools, 'Een canon voor het land van ooit', in: Ons Erfdeel, 50 (2007), pp.186-189.

19 B. De Wever, Over identiteit, Gent 2019.

20 N. Sleiderink, 'Vlaamse canon ziet over twee jaar levenslicht', in: De Tijd, 18 september $2 \mathrm{O} 2 \mathrm{O}$. 
venster in voor 'Veelkleurig Nederland', maar stipte zij het slavernijverleden slechts terloops aan. Bij de herijking in 2020 kreeg de 'De slavernij' een afzonderlijk venster en wordt de migratie van de afgelopen decennia gevat onder de veel explicietere noemer 'Gastarbeid'. ${ }^{21}$

Parallel met de canonisering van het nationale verleden eisen etnische minderheden een stem op in het publieke debat en claimen zij plaatsen in het monumentale landschap van de natie. ${ }^{22}$ Zo onthulde koningin Beatrix in 2002 het Nationaal Monument Slavernijverleden in het Amsterdamse Oosterpark. Precies tien jaar later kwam er in de Franse stad Nantes een soortgelijk Mémorial de l'abolition de l'esclavage. ${ }^{23}$ Ook in België krijgt de dekolonisering van de publieke ruimte langzamerhand gestalte. Zo werd in 2018 in Brussel eindelijk een plein hernoemd als de Square Patrice Lumumba, naar de eerste premier van het onafhankelijke Congo. In de zomer van 2020 gingen dan weer verschillende beelden van Leopold II en diens koloniale trawanten tegen de vlakte of werden ze beklad. ${ }^{24}$

Het is een illusie om te denken dat de geschiedwetenschap immuun is voor zulke maatschappelijke ontwikkelingen. Emancipatiebewegingen hebben van oudsher nieuwe wegen in het onderzoek geopend. Een goed voorbeeld hiervan zijn de vrouwenstudies; in het kielzog van de tweede feministische golf nam de aandacht voor de positie van vrouwen in de geschiedenis toe - aanvankelijk gebeurde dat op een wat activistische manier, maar inmiddels is het vanzelfsprekend dat geschiedenis niet meer een Geschiedenis van Grote Mannen kan zijn. Geschiedenis herschrijven, dat is iets wat historici nu eenmaal doen. ${ }^{25}$ En terwijl Mark Rutte Zwarte Piet altijd heeft geroemd als een Nederlandse traditie, gaf hij in 2020 na jarenlange protesten van onder

21 Cf. CanonvanNederland.nl (geraadpleegd 28 september 2020).

22 Cf. J. Dewulf, 'Amsterdam Memorials, Multiculturalism, and the Debate on Dutch Identity', in: M. de Waard (red.), Imagining Global Amsterdam. History, Culture and Geography in a World City, Amsterdam 2012, pp.239-254.

23 Cf. http://memorial.nantes.fr/ (geraadpleegd 28 september 2020).

24 Cf. G. Buelens, 'Brave jongens voor de Volkenbond. De Vlaamse intellectuele elite en Congo', in: De Lage Landen, 63.3 (2020), pp.34-45 en M. Zana Etambala, 'Het werk is nog maar begonnen. De gemiste kansen van een AfricaMuseum', in: D. Van Assche e.a. (red.), Nulpunt 1945. De Lage Landen een mensenleven later, Rekkem en Den Haag 2O2O, pp. $75^{-84}$.

25 Dit leren studenten geschiedenis al vroeg in hun studie. Zie: V. Soen, Geschiedenis is een werkwoord. Een inleiding tot historisch onderzoek, Leuven (2016) en J. Kamp, S. Legêne, M. van Rossum \& S. Rümke, Geschiedenis schrijven! Wegwijzer voor historici, Amsterdam 2016. 
andere de actiegroep Kick Out Zwarte Piet toe: 'Ik heb zelf ook grote veranderingen doorgemaakt over Zwarte Piet'. ${ }^{26}$

Bovenstaande voorbeelden tonen ook dat 'iets vinden van geschiedenis' niet voorbehouden is aan professioneel actieve historici. Het (politieke) gebruik van historische verwijzingen staat echter op gespannen voet met wetenschappelijke geschiedbeoefening. Historici willen liever op een constructieve manier bijdragen aan het historisch bewustzijn van hun publiek dan steeds vanaf de zijlijn het gebruik van historische verwijzingen door anderen bekritiseren. Dat valt hen echter zwaar omdat politici en beleidsmakers geschiedenis vaak gebruiken als een grabbelton waaruit ze naar believen kunnen putten. ${ }^{27}$ Het is in dit opzicht niet zo verwonderlijk dat veel historici van de vroegmoderne Nederlanden sceptisch staan tegenover de politiek-maatschappelijke benutting van hun kennis. Dat roept de vraag op: hoe gaan we best om met deze praktijk?

Deze vraag staat centraal in deze editie van het jaarboek Nieuwe Tijdingen van de Vlaams-Nederlandse Vereniging voor Nieuwe Geschiedenis. De bijdragen, waarvan de meeste groeiden uit lezingen die in november 2018 op het jaarcongres in Leuven werden gehouden, werpen nieuw licht op de vraag hoe en waarom (onderzoek over) de vroegmoderne periode wordt geïnstrumentaliseerd en gerepresenteerd in actuele maatschappelijke debatten, en welke rol vroegmoderne historici daarbij zouden kunnen spelen.

Marjolein 't Hart laat zien dat popularisering van historische kennis problematisch wordt wanneer historisch materiaal op eenzijdige en anekdotische wijze wordt verzameld om daarmee een vooropgezet punt te onderbouwen. Het 'poldermodel' als verklaring voor de op consensus gerichte Nederlandse identiteit is hiervan een tekenend voorbeeld. Door de strijd tegen het water zouden Nederlanders historisch veroordeeld zijn geweest tot samenwerking en proto-democratisch overleg. Historici hebben al gevraagd waarom een vergelijkbaar maar omgekeerd probleem in het oude Egypte - namelijk: de uitnodiging om land te irrigeren - leidde tot een andere uitkomst. Samenwerking was ook daar nodig maar zou juist de weg hebben vrijgemaakt voor dictatoriale farao's; zij waren immers de enigen die mensen konden dwingen

26 Ontwikkelingen rondom het coronavirus, Handelingen Tweede Kamer, 79-10 https://zoek.officielebekendmakingen.nl/h-tk-20192020-79-10.html (geraadpleegd 12 augustus 2020).

27 Zie ook: J. van der Steen, 'Selectief winkelen in het verleden', in: Het Parool, 26 januari 2015. 
gedisciplineerd en gecoördineerd te werk te gaan. ${ }^{28}$ In haar stuk betoogt 't Hart dat de nadruk op de veronderstelde continuïteit van de Nederlandse overlegcultuur voorbijgaat aan de vele momenten waarbij niet overleg maar conflict de loop van de Nederlandse geschiedenis bepaalde. Recht op medezeggenschap was expliciet geen Nederlands automatisme; het moest juist continu worden bevochten.

Het Nederlandse slavernijverleden is, zoals hierboven reeds bleek, een goed voorbeeld van het belang van de vroegmoderne periode voor hedendaagse identiteitsvorming. In zijn bijdrage laat Karwan Fatah-Black zien dat de poging van nazaten van tot slaaf gemaakten om erkend te worden als onderdeel van de Nederlandse cultuur vaak als een splijtzwam in de samenleving wordt ervaren. Met name populistische politici beschuldigen activisten van een 'weg-met-ons'-mentaliteit. Fatah-Black betoogt echter dat extreme politisering van het debat geen kerneigenschap is van de slavernij-herdenkingsbeweging, die juist wordt gekenmerkt door inclusiviteit, emancipatie en verzoening. Nazaten spelen dus een constructieve rol in de manier waarop samenlevingen om zouden moeten gaan met hun koloniaal verleden. Dit inzicht over het belang van nazaten resoneert met recent onderzoek van Idesbald Goddeeris, die de bijna afwezigheid van bijvoorbeeld Congolese verwijzingen in het Brusselse straatbeeld onder andere verklaarde aan de hand van de kleine en gemarginaliseerde gemeenschap Congolezen in Brussel. ${ }^{29}$

Emancipatie van historisch gemarginaliseerde groepen mensen leidt vaker tot een herwaardering van aspecten van de geschiedenis die lang onderbelicht zijn gebleven. Beeldvorming speelt hierin een belangrijke rol. Recent besloten een aantal Nederlandse universiteiten hun portrettengalerijen aan te passen door er meer vrouwelijke wetenschappers in op te nemen en zo op symbolische wijze genderongelijkheid tegen te gaan. Dit was voor Lieke van Deinsen een aanleiding om onderzoek te doen naar historisch ingesleten beeldvormingspatronen die genderongelijkheid in stand houden. Zij demonstreert dat niet alleen de negentiende-eeuwse beeldvorming van de mannelijke wetenschapper verantwoordelijk is voor het dominante beeld van de wetenschapper als witte man op gevorderde leeftijd. Ook in de vroegmoderne tijd

28 R. Dekker, Meer verleden dan toekomst. Geschiedenis van verdwijnend Nederland, Amsterdam 2008, pp.54-55.

29 I. Goddeeris, 'Square de Léopoldville of Place Lumumba? De Belgische (post)koloniale herinnering in de publieke ruimte', in: Tijdschrift voor Geschiedenis 129.3 (2016), pp.349-372, aldaar p.369. 
bepaalden sociaal-maatschappelijke verwachtingspatronen en associaties hoe er naar vrouwelijke geleerden werd gekeken.

Zoals het poldermodel in populair-historische publicaties en verwijzingen de historische continuïteit van de Nederlandse overlegcultuur moet onderstrepen, staat de Tachtigjarige Oorlog vaak symbool voor het vrijheidslievende karakter van de Nederlandse natie. Met name het opkomende nationalisme van de laatste twee decennia heeft geleid tot een roep om herwaardering van 'ons' Opstandsverleden. Bij deze roep hoort ook het pleidooi voor een nieuwe Nederlandse feestdag, gekoppeld aan de Opstand. Anton van der Lem legt in zijn bijdrage uit dat het begrijpelijk maar toch ook problematisch is om gebeurtenissen uit de Tachtigjarige Oorlog - die in haar vroege stadia een burgeroorlog was in het statencomplex van de Zeventien Nederlanden te vieren op een nieuwe nationale feestdag in het Koninkrijk der Nederlanden. Hij oppert om in de plaats daarvan de Brabantse Blijde Intrede van 1356 te vieren als Benelux-dag.

Ten slotte duikt Hans Cools in de ontstaansgeschiedenis van de cultus voor Rembrandt en Rubens in respectievelijk Amsterdam en Antwerpen. De aanvankelijke heldenverering in negentiende-eeuwse steden die zochten naar een inspirerend voorbeeld om trots op te zijn, maakte van beide schilders exponenten van stad en land. Tegelijkertijd leidde de aandacht voor deze twee schilders in Amsterdamse en Antwerpse kunstmusea tot discussies die tot de dag van vandaag lopen over de lokroep van het massatoerisme, historische authenticiteit en het eigenlijke doel van de museale tentoonstelling van beide schilders.

Uit de bijdragen aan dit jaarboek blijkt dat historici automatisch een rol hebben in de maatschappelijke benutting van historische kennis, of ze die rol nu ambiëren of niet. ${ }^{30}$ Publieke belangstelling voor het verleden is belangrijk, zij versterkt het draagvlak voor het werk van historici. Tegelijkertijd voelen diezelfde historici zich ongemakkelijk wanneer anderen die niet worden gehinderd door de wetenschappelijke eisen die het historische veld stelt, zoals invloedrijke opiniemakers of politici, het verleden voor hun karretje spannen. Een clichématige reactie is dan om te reageren: 'nee het ligt ingewikkelder' en het daarbij te laten. Of: 'amateurs mogen dan misschien aan de haal gaan met de geschiedenis, wij historici houden ons daar niet mee bezig.' Maar een dergelijke reactie heeft iets onbevredigends. De historicus A.Th. van Deursen (1931-2011) zag het allereerst als zijn taak om 'recht [te] doen aan de doden'. 'Je moet met de gestorvenen in beginsel niet anders omgaan dan met de levenden', aldus Van 
Deursen. Men mocht volgens hem 'over geen van beiden [...] onwaarheid vertellen. Je moet proberen hun verlangens en bedoelingen te begrijpen.' ${ }^{31}$ De grote vraag blijft dan natuurlijk: aan welke doden willen en moeten historici in eerste instantie recht doen? Wiens levens reconstrueren zij en wie laten zij achter in de vergeetput van het verleden? Deze vragen vormen in 2020 hét snijpunt tussen de actualiteit en de historische wetenschap. De auteurs in dit jaarboek laten zien dat het mogelijk is voor historici om zich te mengen in hedendaagse debatten, hun maatschappelijke plichten als geïnformeerde burgers te vervullen, ja zelfs zich af en toe activistisch te tonen en tegelijkertijd hun onderzoek volgens de regels van de historische wetenschap te presenteren. Zeker in een tijd waarin het verleden in toenemende mate gepolitiseerd raakt is het belangrijk dat historici zichzelf niet wegcijferen. Kritische reflectie op historische verwijzingen in actuele debatten is dus noodzakelijk, maar historici dienen haar te combineren met een constructieve visie op het verleden.

Jasper van der Steen is postdoc-onderzoeker aan de Universiteit Leiden. Hij werkt momenteel aan zijn NWO veni-project 'The Nassaus and the Family Business of Power in Early Modern Europe'.

Hans Cools is als hoofddocent werkzaam bij de Onderzoeksgroep Geschiedenis van de Nieuwe Tijd van de KU Leuven. In zijn onderwijs en onderzoek legt hij zich toe op de politieke en sociale geschiedenis van de vroegmoderne Lage Landen, Frankrijk en Italië. Daarnaast heeft hij bijzondere belangstelling voor de plaats van de vroegmoderne periode in de hedendaagse historische cultuur.

31 W. Bergsma, 'Gepredestineerde kolen en dieven. Naar aanleiding van A.Th. van Deursens Bavianen en slijkgeuzen', in: Idem (red.), Gelovigen, dominees en geleerden. Opstellen over Friese en Nederlandse geschiedenis in de vroegmoderne tijd, Hilversum 2019, pp.283-315 en M. Wallet, 'Van Deursen: Recht doen aan de gestorvenen', in: Reformatorisch Dagblad, 20 juni 2011. 



\title{
Polderen en ploeteren
}

\section{Een debat over geschiedenis, continuïteit en Nederlandse identiteit ${ }^{1}$}

\author{
Marjolein 't Hart
}

\begin{abstract}
Het 'poldermodel' als verklaring voor de op consensus gerichte Nederlandse identiteit is teveel gebaseerd op een anekdotisch besef van de geschiedenis. Deze bijdrage betoogt dat de veronderstelde continuïteit van een overlegcultuur voorbijgaat aan de vele momenten waarbij niet overleg maar conflict de loop van de Nederlandse geschiedenis bepaalde. Bij besluitvorming in het verleden werd slechts rekening gehouden met specifieke gildeleden, met boeren die minstens 50 morgen land bezaten, of met de mannelijke leden van rijke regentenfamilies. En ook voor hen was het recht op zeggenschap geen Nederlands automatisme: dat moest altijd weer bevochten worden.
\end{abstract}

"Bovenal is Nederland één groot onderhandelingshuishouden gebleven. Hierin vergaderen de betweterige bewoners, uiteraard op beschaafde toon en met respect voor elkaars standpunten, eindeloos om de lieve vrede te bewaren. Samen komen we er wel uit, denken de Nederlanders. En dat blijkt nog vaak te kloppen ook."2

$\mathrm{Z}$ o eindigt de historische conclusie van het publieksboekje Alles wat je moet weten over Nederland. Het getuigt van de veronderstelling dat 'we' al eeuwenlang op een respectvolle manier met andere, afwijkende opvattingen omgaan, gericht als 'we' zouden zijn op compromis en consensus. Sinds de jaren 1990 kwam hier de term poldermodel voor in de mode. ${ }^{3}$ Kranten gebruikten de benaming om de samenwerking

2 G. van der List, 'Een eigenwijs, tolerant, burgerlijk vergadervolk', in: A. Joustra (red.), Alles wat je moet weten over Nederland. Een liefhebbende gids, Amsterdam 2019, pp.15-22, aldaar p.22. Van der List promoveerde in de politicologie, maakte deel uit van de Teldersstichting en is momenteel redacteur bij Elsevier Weekblad.

3 M. van Tielhof, 'Waterschappen als oudste democratische instellingen van Nederland. Het ontstaan van een mythe', in: Tijdschrift voor Waterstaatsgeschiedenis 25.2 (2015), pp.87-98, aldaar p.96. 
tussen overheid, werkgevers en vakbonden te bejubelen, niet in het minst omdat deze economische groei mogelijk zou maken. Publieksgerichte historici droegen het clichébeeld van het poldermodel succesvol naar buiten. ${ }^{4}$ Het poldermodel bleek ook van nut voor de vernieuwende politieke samenwerking in het 'paarse' kabinet van Wim Kok.

De laatste jaren horen we naast de jubeltonen ook andere geluiden. Sociale wetenschappers stellen dat 'het' poldermodel hapert; sommigen verklaren het zelfs dood. ${ }^{5}$ Dat is een interessante wending. Als 'we' er nu ineens niet meer 'met elkaar uitkomen', werpt dat de vraag op hoe het met de continuïteit van het poldermodel in het verdere verleden zat.

Wat moeten we doen als populariserende literatuur een beeld van de geschiedenis geeft dat op gespannen voet met een getrouwe en verantwoorde weergave van het verleden staat? ${ }^{6}$ Wat moeten we doen met de claim dat het poldermodel eeuwenoude wortels heeft en allesbepalend is voor de Nederlandse identiteit? Hier staan twee prominente werken uit de hoogtijdagen van het debat over het poldermodel centraal: Het polderdenken (2005) van Jona Lendering en Erasmus en het poldermodel (2005) van Herman Pleij. Zij zijn al reeds van wat oudere datum, maar gebruiken argumenten die steeds weer opnieuw worden gehoord, en met merkbaar resultaat, getuige het citaat aan het begin van dit artikel.

Beide werken zijn gericht op het grotere publiek, maar ook geschreven door academici met een uitstekende staat van dienst. Voor de buitenwacht is die academische status wel degelijk van groot belang: deze boeken zijn niet alleen interessant, maar hoogstwaarschijnlijk ook waar. Beiden spraken zich uitzonderlijk kernachtig uit. Pleij stelde

6 Dit was een centrale vraag op het Jaarcongres 2018, genoemd in noot 1. 
bijvoorbeeld: 'Wie tegen het poldermodel is, is tegen Nederland'.7 Lendering deelde deze visie:

Het streven naar consensus is Nederlanders zó dierbaar dat ze er nooit afscheid van zullen nemen. Het einde van de overlegcultuur zou per slot van rekening niets anders zijn dan het einde van de Nederlandse nationale identiteit. ${ }^{8}$

De toonaangevende academische positie van de auteurs maakt het noodzakelijk dat historici zich om hun uitspraken zouden moeten bekommeren.

Dit artikel begint met een korte stand-van-zaken van recente analyses over het poldermodel. Vervolgens komen de twee bovengenoemde populariserende werken aan bod betreffende 1) de invloed van het waterbeheer op het poldermodel, inclusief de claim dat de waterschappen tot de oudste democratische instellingen van Europa zouden behoren; en 2) de historische doorwerking van de verstedelijkte, burgerlijke, egalitaire en tolerante samenleving op de tijd van nu. Een state-of-the-art analyse zal hun uitspraken in een meer academische context plaatsen. Een discussie over de vermeende continuïteit van het poldermodel volgt. De conclusie bekijkt of Europa uiteindelijk echt 'iets waardevols' van de Nederlandse geschiedenis kan leren, ${ }^{9}$ dankzij dit 'unieke instrument'. ${ }^{10}$ Of moeten we eerder over een 'ploetermodel'11 dan over een poldermodel praten, omdat in de praktijk al dat gepraat lang niet altijd tot echte consensus leidt?

$7 \quad$ H. Pleij, over zijn boek Erasmus en het poldermodel in W. Kieskamp, 'Wie tegen het poldermodel is, is tegen Nederland', in: Trouw, 9 april 2005. Pleij is emeritus hoogleraar Nederlandse historische letterkunde. Erasmus en het poldermodel verscheen in 2012 ook als luisterboek.

8 Lendering, Polderdenken, p.134. Lendering studeerde geschiedenis en specialiseerde zich in de oudheid, ontving de Oikos-publieksprijs in 2010, is journalist en medeoprichter van Livius Onderwijs, een onafhankelijke school voor historisch onderwijs.

9 Lendering, Polderdenken, p.9.

10 Pleij, Erasmus en het poldermodel, p.106.

11 Term geïnspireerd door J. de Vries, 'Questioning the polder model concept', in: Bijdragen en Mededelingen betreffende de Geschiedenis der Nederlanden, 129.1 (2014), pp.99-111. 


\section{De reikwijdte van het poldermodel}

Een poldermodel houdt in: 'overleg om consensus te bereiken'. De term is vaag; volgens sommigen ook 'bewust vaag', want alleen daardoor kunnen 'partijen met zulke tegengestelde belangen (...) elkaar vinden'. ${ }^{12} \mathrm{Er}$ is ook absoluut geen helderheid over een term als 'consensus'.13 Sociale wetenschappers spreken liever over neocorporatisme dan over een poldermodel. In het neocorporatisme hebben specifieke organen en verenigingen geprivilegieerde posities in de onderhandelingen met de overheid. ${ }^{14}$ De deelname van de 'gewone man' is daarin beperkt. De geprivilegieerde toegang tot overleg betekent dat er in de praktijk veel minder mensen 'aan de knoppen draaien' dan voorstanders van het poldermodel vaak denken. ${ }^{15}$

Dit stelsel van onderhandelen zorgde wel dat Nederland zich kenmerkte door relatief weinig stakingen na de Tweede Wereldoorlog. Bij het sluiten van de mijnen viel het bijvoorbeeld op dat dit proces in Nederland rustig en gelijkmatig verliep, in goed overleg met de bonden, zonder bloedige protesten, in scherp contrast tot wat er in Wallonië gebeurde. ${ }^{16}$ Instellingen als de SER (Sociaal-Economische Raad), de STAR (Stichting van de Arbeid), en het decentrale cao-overleg vertoonden een opmerkelijke continuïteit en legden de rechtsstatelijke fundering voor de overlegeconomie. ${ }^{17}$ Deze instituties bevorderden het overleg waarin politiek, bedrijfsleven en vakbonden de loonpolitiek vormgaven. Een uitgebreide verzorgingsstaat werkte ook een tijd lang dempend op arbeidsonrust. Jelle Visser en Anton Hemerijck zagen dat de onderhandelingspartners daarbij via een 'responsief corporatisme' een geslaagde strategie van loonmatiging hadden weten te bewerkstelligen. Dit was nodig in verband met de steeds

12 Lendering, Polderdenken, 131.

13 F. Lechner, The Netherlands: Globalization and National Identity, Londen 2008, pp.61, 200.

14 P. de Beer \& M. Keune, 'De erosie van het poldermodel', in: Mens en Maatschappij, 93 (2018), pp.231-26o, aldaar 232.

15 M. van Faassen, Polder en emigratie. Het Nederlandse emigratiebestel in internationaal perspectief 1945-1967, Groningen 2014, p.417.

16 E. Nijhof, '1965: Polderen in de Mijnstreek', in: L. Heerma van Voss e.a. (red.), Wereldgeschiedenis van Nederland, Amsterdam 2018, pp.641-646.

17 L. Delsen, Exit poldermodel? Sociaal-economische ontwikkelingen in Nederland, Assen 2000, pp.11-14. 
sterkere internationale concurrentie. Het poldermodel faciliteerde een mechanisme van 'beleidsleren', met als resultaat dat de economie in de jaren 1990 kon groeien. ${ }^{18}$

$\mathrm{Al}$ met al is 'het poldermodel' dus een containerbegrip waar verschillende auteurs verschillende kenmerken van benadrukken. De Utrechtse historici Maarten Prak en Jan Luiten van Zanden borduurden voort op de positieve effecten op de economie. Zij concludeerden in hun boek Nederland en het poldermodel dat het poldermodel de Nederlandse economische groei door de eeuwen heen had bevorderd. Alleen wanneer de overheid weinig rekening hield met organisaties in de samenleving, en niet met hen in overleg trad, stagneerde de economie. ${ }^{19}$ Maar in correlaties is niet altijd een causaal verband. De vraag is te stellen of het niet eerder zo was dat 'polderen' eenvoudigweg kón in een tijd van economische groei. ${ }^{20}$ Dit geldt ook voor het werk van Visser en Hemerijck: misschien bewerkstelligde het gunstige economische klimaat van de jaren 1990 de werking van de overlegstructuren, en niet andersom. In ieder geval laten analyses van landen met het Rijnlandse model (met uitgebreid stelsel van sociale zekerheid en regulier overleg tussen overheid, werkgevers en werknemers, waar het poldermodel onder valt) en het daaraan tegenovergestelde Angelsaksische conflictmodel (gedreven door concurrentie en individuele verantwoordelijkheid) zien dat het economische systeem (Rijnlands of Angelsaksisch) niet bepalend is voor wel of geen groei. ${ }^{21}$

Regelmatig overleg kan ook heel goed te maken hebben met een ander aspect: de grote private non-profit sector in Nederland. Sinds de Tweede Wereldoorlog is deze in internationaal opzicht uitzonderlijk uitgebreid op gebieden waar deze elders tot de overheidstaken horen. Denk daarbij met name aan woningcorporaties, publieke omroepverenigingen, onderwijsorganisaties, pensioenfondsen, en gezondheidszorg (zorgaanbieders en zorgverzekeraars). Er gaan veel collectieve middelen naar

18 J. Visser \& A. Hemerijck, Een Nederlands mirakel? Beleidsleren in de verzorgingsstaat, Amsterdam 1998, pp.196-197, 233.

19 M. Prak \& J. L. van Zanden, Nederland en het poldermodel. Sociaal-economische geschiedenis van Nederland, 1000-2000, Amsterdam 2013.

20 M. 't Hart \& K. Davids, 'Is the polder model good for the economy? A new interpretation of Dutch economic and social history', in: BMGN, 129.1 (2014), pp.90-98.

21 Delsen, Exit poldermodel, p.173. 
deze bedrijven, en de Nederlandse overheid moet dus altijd meer met private partners onderhandelen dan in het buitenland. ${ }^{22}$

Een recente analyse van twee hoogleraren arbeidsrecht, Paul de Beer en Maarten Keune, wijst echter op een 'erosie van het poldermodel'. In de fameuze cao-onderhandelingen, hét cruciale instrument van de overlegeconomie, moet de factor arbeid het meer en meer afleggen tegen de factor kapitaal. De belangen van de werkgeversorganisaties wegen het zwaarst, waarbij met name multinationale ondernemingen aan invloed winnen. De laatste twee decennia verloren vakbonden feitelijk de greep op de loonontwikkelingen, en dat ondanks een stijgende gemiddelde arbeidsproductiviteit. Het gezag van de vakbonden nam af door een toename van flexibele arbeid en een gestage teruggang in het aantal vakbondsleden, terwijl werkgeversorganisaties stabiel bleven. Vakbonden zijn zelfs bijna geheel uit uitvoeringsorganisaties van de sociale zekerheid verdwenen, met als enige uitzondering de pensioenen. ${ }^{23}$

Ook Anton Hemerijck ziet nu, samen met zijn collega Marc van der Meer, dat de veranderende economische condities de maatschappelijke pijlers hebben verzwakt. Zij wijzen daarnaast op de versplintering van het politieke midden in het parlement, zodat partijen elkaar moeilijker weten te vinden. ${ }^{24}$ Prak en Van Zanden stelden in hun boek dat polderen alleen positief uitwerkt als er een sterke centrale macht is die knopen kan doorhakken. ${ }^{25}$ In Nederland is echter een toenemende politieke fragmentatie te zien. ${ }^{26}$ De veelvuldig gehoorde kritiek op de achterkamertjespolitiek is ook niet bevorderlijk voor het poldermodel. In Arend Lijpharts klassieker Verzuiling, pacificatie en kentering in de Nederlandse politiek waren achterkamertjes essentieel. Er was immers sprake van

22 S. de Waal, 'Transformatie van publiek leiderschap', in: G. van den Brink (red.), Waartoe is Nederland op aarde? Nadenken over verleden, heden en toekomst van ons land, Amsterdam 2018, pp.269-299, aldaar 283-285. Het aandeel private for public bedraagt in Nederland 15 tot 30 procent van het Bruto Nationaal Product. De meeste landen komen maar tot drie procent, terwijl slechts enkele landen vijf tot zeven procent halen.

23 De Beer \& Keune, 'De erosie van het poldermodel', pp.242, 247-248.

24 A. Hemerijck \& M. van der Meer, 'Nieuw Nederlands Polderen. Van brede sociale akkoorden naar ad hoc hervormingscoalities,' in: M. Keune (red.), Nog steeds een mirakel? De legitimiteit van het poldermodel in de eenentwintigste eeuw, Amsterdam 2016, pp.167-195, aldaar pp.194-195.

25 Prak \& Van Zanden, Nederland en het poldermodel, p.2.

26 E. Engelen 'De keerzijde van het polderwonder', in: M. Keune (red.), Nog steeds een mirakel? De legitimiteit van het poldermodel in de eenentwintigste eeuw, Amsterdam 2016, pp.115-142, aldaar p.141. 
eliteoverleg waarbij de achterban passief bleef. ${ }^{27}$ Het 'verkopen van besluiten aan de achterban', dat nu nodig is, brengt een verharding van de tegenstellingen met zich mee en zorgt ook nog voor een sterker contrast tussen mensen mét en mensen zonder werk. Nu 'stille' politiek niet meer mogelijk is, is de centrale beleidsruimte verminderd. ${ }^{28}$ Deze verharding was tevens merkbaar bij de hervorming van de verzorgingsstaat. De Nederlandse regering bleek overijverig bij de bezuinigingen, die vooral snel moesten geschieden. ${ }^{29}$ In dat proces was geen sprake van 'beleidsleren' of 'harmonieus' gepolder tussen de partijen. Machtspolitiek en zeer krap behaalde meerderheden in de Tweede Kamer domineerden, zodat Nederland in internationaal opzicht helemaal niet zo afwijkend was. ${ }^{30}$

Zo kon het poldermodel volgens sociale wetenschappers dus in korte tijd, in ieder geval vanaf het eind van de jaren 1990 tot eind jaren 2010, behoorlijk aan invloed verliezen. Hoe zat het dan met de continuïteit in het verdere verleden?

\section{Polderen in het waterbeheer}

Want dat er een continuïteit in het polderen was, dat staat voor zowel Pleij als Lendering als een paal boven water. Voor Pleij kán dat ook niet anders, want 'de relatieve onbestuurbaarheid van het Noorden van de Lage Landen ten gevolge van de waterige conditie' heeft voor de egaliserende verhoudingen in Nederland gezorgd.

De gebruikelijke hiërarchische verhoudingen krijgen geen vat op de polder, klei en turf (...). Dat plaatst de middeleeuwse ontginners en exploitanten (...) van meet af

27 J. Hertog, 'Stille politiek en de pacificatie van 1917', in: D. Bos, M. Ebben \& Henk te Velde (red.), Harmonie in Holland. Het poldermodel van 1500 tot nu, Amsterdam 2007, pp.176-193, aldaar p.19o.

28 A. Verhoeff, 'In de schaduw van de markt? Een reflectie op de robuustheid van looncoördinatie via doorwerking', in: M. Keune (red.), Nog steeds een mirakel? De legitimiteit van het poldermodel in de eenentwintigste eeuw, Amsterdam 2016, pp.225-253, aldaar p.251-253; Delsen, Exit poldermodel, p.75.

29 Delsen, Exit poldermodel, p.175.

30 Lechner, The Netherlands, pp.199-200. 


\section{Marjolein 't Hart}

aan in een toch wel merkwaardige positie van gelijkheid en ongedwongen samenwerking. ${ }^{31}$

Lendering is wat specifieker hoe dat dan oorspronkelijk in zijn werk ging. De Hollandse graaf ondersteunde deze initiatieven 'van onderop' volop. Daarbij sloeg hij wel een modderfiguur bij de Europese adel:

Vanuit het traditionele, feodale standpunt bezien was de graaf eigenlijk maar een zwakkeling met zijn erkenning van de waterschappen. Een beetje landsheer overlegde niet met zijn onderdanen, maar commandeerde hun wat ze te doen hadden. Het idee om op voet van gelijkheid van gedachten te wisselen met ongeletterden stuitte menig Europese landsheer tegen de borst. Zoiets werd overgelaten aan de lokale edelen. Maar de graaf van Holland passeerde de aristocraten. ${ }^{32}$

Lendering wijst verder op de opmerkelijke solidariteit vanuit verder gelegen gemeenschappen die veel minder directe belangen hadden bij een dijk. In deze 'baanbrekende vernieuwing', een 'unieke constructie', beschouwden de Hollandse graven hun onderdanen 'als gelijkwaardige gesprekspartners'. ${ }^{33}$ De graaf werkte 'steeds zo harmonieus mogelijk samen met zijn onderdanen.(...). Slechts een enkele keer schreef hij iets dwingends voor.' 34

Beide auteurs baseren zich in hun betoog vooral op de geschiedenis van de provincie Holland, het gewest dat zo nadrukkelijk zijn stempel heeft gezet op de politieke cultuur van Nederland. Daarom volgt hier niet een nuancering betreffende de andere gang van zaken in andere gewesten, maar hoe specialisten de geschiedenis van Holland zien. Die schetsen toch een heel ander beeld. 'Met name het aantrekkelijke beeld van een grafelijk beleid dat de persoonlijke vrijheid van plattelandsbewoners stimuleerde, wordt toenemend door historici betwijfeld', stelt Milja van Tielhof. ${ }^{35}$ Er was aanvankelijk zelfs sprake van horige arbeid in de veenontginningen. Arjan Nobel analyseerde de rol van de ambachtsheren en maakte korte metten met de door Pleij veronderstelde

31 Pleij, Erasmus en het poldermodel, p.27.

32 Lendering, Polderdenken, p.38.

33 Ibid, pp.8, 36-37.

34 Ibid, p.39.

35 M. van Tielhof, 'Betrokken bij de waterstaat. Boeren, burgers en overheden ten zuiden van het IJ', in: E. Beukers (red.), Hollanders en het Water. Twintig eeuwen strijd en profijt, Hilversum 2007, pp.61-98, aldaar p.64. 
afwezigheid van feodale structuren in de waterschappen. Deze lokale adel bemoeide zich vergaand met de dagelijkse gang van zaken en streed voortdurend met andere ambachtsheren over grenskwesties, wat resulteerde in langdurige en kostbare rechtszaken. ${ }^{36}$ Lokale gemeenschappen kunnen wel een initiërende rol hebben gespeeld, maar de lokale adel en kloosters namen waarschijnlijk vaker het initiatief. De ontginning van het latere Delfland werd in de dertiende eeuw zelfs door het grafelijke hof van Delft ter hand genomen. ${ }^{37}$ Het grafelijke gezag luisterde wel naar lokale opvattingen, en via goede landregistraties probeerde het toestemming van de landeigenaars te krijgen voor de verhoging van een belasting. ${ }^{38}$ Maar er was geen sprake van onderdanen als 'gelijkwaardige onderhandelingspartners', want waterschappen raakten al snel onder invloed van een proces van oligarchisering. De heemraden van Delfland moesten bijvoorbeeld minstens 50 morgen land bezitten. ${ }^{39} \mathrm{Zij}$ kregen net als in de andere streekwaterschappen deze benoeming voor het leven. Indien een van de heemraden stierf kwam de vervanger via coöptatie binnen. ${ }^{40}$

De solidariteit van de meer in het binnenland gelegen gemeenschappen was bovendien allerminst vanzelfsprekend. In Noord-Holland blokkeerde Edam decennialang een efficiënte bovenlokale oplossing voor het waterbeheer ten koste van bijna alle landeigenaren in de regio. ${ }^{41}$ Ook in andere waterschappen was de solidariteit vaak ver te zoeken. ${ }^{42}$ In het achttiende-eeuwse Zeeland verliep samenwerking in het wa-

36 A. Nobel, 'Polderen in de polder? Consensus en conflict in een vroegmodern poldergebied', in: D. Bos, M. Ebben \& Henk te Velde (red.), Harmonie in Holland, pp.30-48, aldaar pp.34-35, 41 en 47 .

37 D. Aten, 'Pioniers langs de waterkant. De vroegste bewoners van "Holland" en het water', in: E. Beukers (red.), Hollanders en het water, pp.23-60, aldaar pp.26, 31; Van Tielhof, 'Betrokken bij de waterstaat', pp.63-65; C. Postma, Het hoogheemraadschap van Delfland in de middeleeuwen 1289-1589, Hilversum 1989, pp.23-24.

38 M. van Tielhof, 'Regional planning in a decentralised state: how administrative practices contributed to consensus-building in sixteenth-century Holland', in: Environment and History 23.3 (2017), pp.431-453, aldaar pp.439-441, 444, 448.

39 Een Delflandse morgen was wat minder dan een hectare, namelijk circa $8500 \mathrm{~m}^{2}$.

40 Postma, Het hoogheemraadschap van Delfland, pp.66-67, 402-403; M. van Tielhof \& P. van Dam, Waterstaat in stedenland. Het hoogheemraadschap van Rijnland voor 1857 , Utrecht 2006, p.48.

41 Van Tielhof, 'Regional planning in a decentralized state', p.452.

42 Van Tielhof en Van Dam, Waterstaat in stedenland, pp.70, 73-74. 
terbeheer bijzonder moeizaam. Gemeenschappen die minder directe gevolgen van dijkdoorbraken ondervonden, lieten de 'calamiteuze polders' aan hun lot over. ${ }^{43}$

Dat wil niet zeggen dat er geen overleg was. ${ }^{44}$ Het octrooi tot droogmaking van de Beemsterpolder van 1607 nam de clausule op dat droogmakers verplicht waren om over compensatie te onderhandelen met vissers, schippers, landeigenaars, of anderen die zich door het octrooi benadeeld voelden: de contentement clausule. Dit leek in de praktijk te werken. Vóór 1607 duurden waterstaatprojecten veel langer vanwege de vele rechtszaken die deze opriepen. De nieuwe clausule kwam in de meeste latere octrooien standaard voor. Maar niet ging het er altijd 'eerlijk' aan toe. In het geval van de Beemster manipuleerde landsadvocaat Van Oldenbarnevelt het politieke goedkeuringsproces in de Staten van Holland. Hij had de politieke steun van Amsterdamse Beemster-financiers nodig om in te stemmen met een staakt-het-vuren met Spanje, en zorgde dat het hele octrooi was goedgekeurd voordat steden als Alkmaar en Hoorn, die anders behoorlijk dwars hadden kunnen liggen, hun ruggenspraak hadden kunnen organiseren. ${ }^{45}$

Lendering claimde ook dat de waterschappen 'tot de oudste representatieve lichamen van Europa' zouden behoren. ${ }^{46}$ Deze mythe kent één duidelijke vader. In 1973 kwam rechtshistoricus Hendrik van der Linden met de stelling dat waterschappen een 'functionele democratie' hadden waarin hij zelfs de historische 'ruggengraat' van 'onze Nederlandse democratie' zag. Tot die tijd hadden slechts enkele historici zich sporadisch en fragmentarisch in deze richting geuit. Van der Lindens tekst diende direct de belangen van de waterschappen in die tijd. In de jaren 1970 woedde een discussie over de noodzaak van het voortbestaan van deze instituties. De waterschappen erkenden

43 P. van Cruyningen, 'Sharing the cost of dike maintenance in the south-western Netherlands: comparing 'calamitous polders' in three States, 1715-1795', in: Environment and History, 23.3 (2017), pp.306-383, aldaar pp.370, 379.

44 Zie ook H. Kole, Polderen of niet? Participatie in het bestuur van de waterschappen Bunschoten en Mastenbroek vóór 180o, Hilversum 2017, p.271: 'Brede participatie in de besluitvorming en streven naar consensus deden zich op uiteenlopende momenten in de onderzoeksperiode voor, en deze momenten verschilden per polder.' P. van Cruyningen, '1607: De Beemster en het poldermodel', in: L. Heerma van Voss e.a. (red.), Wereldgeschiedenis van Nederland, pp.207-212.

46 Lendering, Polderdenken, p.38. 
meteen het belang van Van der Lindens framing en hebben zijn stelling wijd en zijd gepropageerd. ${ }^{47}$ Het is dus geen wonder dat ook Lendering deze mythe heeft opgepikt.

Het is echter een misvatting te denken dat iedereen die een groep vertegenwoordigt meteen tot een representatief lichaam behoort. Vertegenwoordigers in of van een waterschap, een gilde, een ondernemingsraad, hebben alleen zeggenschap over zaken die het beheer van het water, de gilde of het bedrijf betreft. De standaard historische literatuur gebruikt de term 'representatieve lichamen' alleen voor vertegenwoordigers die boven de belangen van een specifiek waterschap, gilde of bedrijf kunnen uitstijgen. ${ }^{48}$ Een representatief lichaam brengt vertegenwoordigers van een grotere groep mensen met verschillende achtergronden bij elkaar, meestal van een stad, streek, of land, en onderhandelen met de overheid of centrale macht over alles wat daar ter vergadering wordt gebracht.

Vanuit die optiek zijn waterschappen geen representatieve instituties, en een stadsraad of de Staten van Holland wel. Wat de provinciale staten betreft liep Holland niet voorop. De eerste 'parlementen' ontstonden op het Iberisch schiereiland in Spanje, waar de vorsten van de Reconquista hun inwoners meer rechten moesten geven in competitie met de oudere en beter ontwikkelde islamitische staten die daar nog macht uitoefenden, zoals in 1188 in Léon en Castilië, 1205 in Catalonië, en 1227 in Aragon. Al vóór die periode vergaderde de vorst met de boeren, op initiatief van de laatsten (over boerenmacht gesproken!). ${ }^{49}$

Vergelijkbare, min of meer formele parlementen bestonden ook al in het dertiende-eeuwse Engeland, Frankrijk, Rijnland, Denemarken, Zweden en Schotland. Vlaanderen was uitzonderlijk vroeg, met een zekere 'vertegenwoordiging' van de drie standen in het midden van de dertiende eeuw. ${ }^{50}$ In Holland kregen niet-adellijke vertegenwoordigers pas in het begin van de vijftiende eeuw een stem. Wel

47 Van Tielhof, 'Waterschappen als oudste democratische instellingen', pp.91, 98.

48 W.P. Blockmans, 'A typology of representative institutions in late medieval Europe', in: Journal of Medieval History, 4.2 (1978), pp.189-215; M. Damen, J. Haemers \& A.J. Mann, 'An introduction: political representation. Communities, ideas and institutions in Europe (c. 1200 - c. 169o)', in: Idem (red.), Communities, ideas and institutions in Europe (c. 1200 - c. 1690), Leiden 2018, pp.1-15, aldaar p.4.

49 A.J. Kosto, 'Reasons for Assembly in Catalonia and Aragon, 900-120o', in: P.S. Barnwell \& M. Mostert (red.), Political assemblies in the earlier Middle Ages, Turnhout 2003, pp.133-149; J.L. van Zanden, E. Buringh \& E.M. Bosker, 'The rise and decline of European parliaments, 1188-1789', in: Economic History Review, 65.3 (2012), pp. 835 -861, aldaar p.859.

50 W. Blockmans, Medezeggenschap. Politieke participatie in Europa vóór 180o, Amsterdam, 2020, p.153. 
uitzonderlijk was de bijzonder hoge vergaderfrequentie van de gewestelijke staten van Vlaanderen, Brabant, en Holland. In de vijftiende eeuw kwamen zij vaker bijeen dan bijvoorbeeld de Spaanse zusterparlementen. Dat gebeurde bovendien ook vaker op initiatief van de steden zelf, en niet op gezag van de graaf of hertog. ${ }^{51}$ Maar anders dan bijvoorbeeld de vroege Spaanse parlementen was in Holland geen sprake van een vertegenwoordiging van de boerenstand: de adel moest hen vertegenwoordigen. Het 'gewone volk' op het platteland had dus helemaal niet zoveel te zeggen, niet in de waterschappen en niet in de Provinciale Staten.

\section{Steden en de tolerante overlegcultuur}

Laten we weer terugkeren naar het narratief van Pleij en Lendering. De eerste ziet naast een democratiserende rol van de waterstaat ook eentje voor de scheepvaart: 'Het dagen-, weken- en soms maandenlang verblijf van een groep mannen in een beperkte ruimte van een schip leidde al gauw tot verbroederende vervagingen van de hiërarchie.'52 Dit 'basale egalitarisme' bleek uiterst vruchtbaar voor de ontwikkeling van het kapitalisme in de steden. 'Geen potentaat van buiten [kon er daarna meer in slagen] een duurzame hiërarchie te vestigen op basis van erfelijk leiderschap'. ${ }^{53}$ De Noord-Nederlandse Republiek was in feite gebaseerd op 'commercieel opererende stadstaatjes'. ${ }^{54}$ Binnen de steden zag Pleij dat het bestuur 'een wezenlijke inbreng [ondervond] van de vertegenwoordigingen uit de strak georganiseerde stadswijken.' Ook de ambachtsgilden kenden een representatie in het stadsbestuur, terwijl binnen de gilden zelf 'een klimaat van gezelligheid ontstond die refereert aan het op zichzelf wonderbaarlijke solidariteitsverband tussen meesters, gezellen en knechten.'55

$51 \quad$ R. Stein, Magnanimous Dukes and rising States. The unification of the Burgundian Netherlands, 1380-1480, Oxford 2017, pp.57, 67, 72, 75 .

52 Pleij, Erasmus en het poldermodel, p.52.

53 Ibid, pp.27-28, 31.

54 Ibid, p.28.

$55 \quad$ Ibid, p.31. 
Volgens Pleij waren nergens ter wereld de gilden zo sterk als in Nederland: 'Zij bepaalden wat er in de stad gebeurde.' 56

Lendering heeft een andere lezing over de rol van de gilden. Volgens hem kregen ze juist geen grote politieke invloed:

De graaf en zijn onderdanen waren door hun onderlinge overleg te vertrouwd met elkaar en te tevreden over hun stille bondgenootschap om de gilden als nieuwe politieke factor te dulden. Op deze manier bleven de gilden gezellige belangenverenigingen en ontliepen de stedelijke en landsheerlijke overheden een overname door het bedrijfsleven. ${ }^{57}$

Wel ziet hij net als Pleij een duidelijke band tussen de democratische waterschappen en het stedelijke bestuur:

De boeren die in de veertiende en vijftiende eeuw naar de stad kwamen, brachten de overlegtraditie van de waterschappen met zich mee en het gevolg was dat de steden partij werden in het stille bondgenootschap dat de graaf en zijn onderdanen tegen de adel hadden gesloten. ${ }^{58}$

De stedelijke overlegcultuur kon volgens hem 'alleen tot stand komen omdat de 'gewone man' georganiseerd was en zo over middelen beschikte om de landsheer tot luisteren te dwingen'. Uiteindelijk waren 'de steden via gewestelijke staten hun eigen landsheer'. ${ }^{59}$

Dat zijn aantrekkelijke, makkelijk te begrijpen narratieven, maar toch echt te gesimplificeerd. De sterke invloed van de gilden die Pleij voor Holland ziet wordt door vrijwel alle vroegmodernisten ontkend. ${ }^{60}$ Bovendien beschouwen veel historici gil-

56 Pleij in W. Kieskamp, 'Wie tegen het poldermodel is'.

57 Lendering, Polderdenken, pp.53-54.

58 Ibid, p.49.

59 Ibid, pp.105-106.

60 M. Boone \& Maarten Prak, 'Rulers, patricians and burghers: the Great and the Little Traditions of urban revolt in the Low Countries,' in: K. Davids \& J. Lucassen (red.), A miracle mirrored. The Dutch Republic in European perspective, Cambridge 1995, pp.99-134. Voor de gilden buiten de provincie Holland ligt dat anders. Zie bijvoorbeeld J. Lucassen \& P. Lourens, 'Zunftlandschaften in den Niederlanden und im benachbarten Deutschland', in: W. Reininghaus (red.), Zunftlandschaften in Deutschland und den Niederlanden im Vergleich, Münster 2000, pp.11-43. 
den niet langer als egaliserende of 'inclusieve' instellingen. ${ }^{61}$ En zoals we boven al zagen, waren de boeren die naar de steden trokken onderhands waarschijnlijk eerder bekend met oligarchisch beheer dan met gelijkwaardig overleg. In de stad was het ook niet Lenderings 'gewone man' die over middelen zou beschikken om het politieke beleid te beïnvloeden, maar machtige stedelijke bestuurders en rijke financiers. ${ }^{62} \mathrm{De}$ wijkraden die volgens Pleij invloed op het stadsbestuur hadden, worden door historici eerder gezien als beheersinstrumenten van de burgemeesters om de bevolking in de wijken te controleren. ${ }^{63}$ Bovendien kende maar een fractie van de Hollandse steden deze sociaal-institutionele gelaagdheid, die juist weer veel meer tot bloei kwam in de Zuid-Nederlandse steden. De door beiden geheel veronachtzaamde invloed van 'feodale structuren' of de adel wordt ook geloochenstraft door de standaardliteratuur. ${ }^{64}$ De visie dat de steden 'hun eigen landsheer' werden en dat de Republiek gebaseerd zou zijn op 'commerciële stadstaatjes' is achterhaald en onderhand vervangen door de aandacht voor de juist sterke en efficiënte politieke dynamiek van het gewestelijke niveau, bovenal in Holland. ${ }^{65}$

Ondertussen kenmerkte de Nederlandse Republiek zich inderdaad door overleg, door colleges en instituties die onderling de macht verdeelden. Maar uniek was dat niet. Historici zien dat de meeste steden van Europa een politieke theorie hanteerden waarbij het streven naar consensus bovenaan stond. Dit stimuleerde overal overleg in 'stadsbesturen en gilden, kerkenraden, rechtbanken en armenbesturen'. 66 Prak en Van Zanden zagen vergelijkbare polderconstructies in de brede geografische,

61 S. Ogilvie, The European Guilds: An Economic Analysis, Princeton 2019.

62 M. 't Hart, The making of a bourgeois state. Politics, finances and warfare in the Dutch Republic, Manchester 1993; J.I.A. Ucendo \& M. Limberger (red.), Taxation and debt in the early modern city, Londen 2012.

63 K. Walle, Buurthouden. De geschiedenis van burengebruiken en buurtorganisaties in Leiden (14e-19e eeuw), Leiden 2005, hoofdstuk 1; V. Sleebe, 'Een burgerlijke samenleving. Sociale verhoudingen en groepsculturen', in: Th. de Nijs \& E. Beukers (red.), Geschiedenis van Holland, Deel 36 , Hilversum 2003, pp.365-434, aldaar p.377.

64 M. Damen, De staat van dienst. De gewestelijke ambtenaren van Holland en Zeeland in de Bourgondische periode (1425-1482), Hilversum 2000, p.155 e.v.; H. Cools, Mannen met macht. Edellieden en de moderne staat in de Bourgondisch-Habsburgse landen (1475-1530), Zutphen 2015'2 J. Gabriëls, De heren als dienaren en de dienaar als heer. Het stadhouderlijk stelsel in de tweede helft van de achttiende eeuw, Den Haag 1990.

65 M. 't Hart, The Dutch Wars of Independence. Warfare and commerce in the Netherlands, 1570-1680, Londen 2014, p.153.

66 J. Pollmann, 'Eendracht maakt macht. Stedelijke cultuuridealen en politieke werkelijkheid in de Republiek', in: D. Bos, M. Ebben \& H. te Velde (red.), Harmonie in Holland, pp.134-151, aldaar pp.145, 149, 151 . 
geürbaniseerde strook die zich in Europa van Noord-Italië via Zwitserland, het Rijnland en de Lage Landen tot Groot-Brittannië uitstrekte. ${ }^{67}$ Het is waar dat deze republikeins-politieke cultuur in Nederland relatief lang, tot 1795, in stand bleef, vergeleken met de meeste andere landen van Europa. Maar van een gelijkwaardig overleg was geen sprake. In de praktijk legde de economisch sterkste partij toch altijd meer gewicht in de schaal. ${ }^{68}$ En breed gedragen was de consensus zeker niet altijd. Bij de Dordtse Synode hadden de contraremonstranten bijvoorbeeld alle macht om de uitkomst van de synode als 'consensus' te bestempelden, terwijl de remonstranten in feite met lege handen achterbleven en sommigen zelfs in ballingschap gingen. ${ }^{69}$

Nog weer even terug naar Lendering en Pleij. Volgens de eerste had 'de' Hollander 'een diepe behoefte [...] aan vrijheid'. ${ }^{70}$ Voor Pleij is het evident dat Erasmus het fundament had gelegd dat de uitwisseling van verschillende zienswijzen bevorderde. Willem van Oranje ziet hij daarbij als beste 'leerling van Erasmus', 'misschien zonder [dat hij] één woord van hem [had] gelezen.' De stadhouder had immers vanaf 1572 'een oorlog met Spanje uitgevochten om de gewetensvrijheid tot grondslag te kunnen maken van de Republiek'. ${ }^{71}$

Hiermee is Willem van Oranje eigenlijk gepromoveerd tot architect van het poldermodel. ${ }^{72}$ Uiteraard had hij invloed op de inrichting van de Nederlandse Republiek. Het is ook bekend dat hij een voorstander van religievrede was en dat hij potentiële aanhangers niet van zich wilde vervreemden door een scherpe keuze voor één religie

67 Prak en Van Zanden, Nederland en het poldermodel, p.278. Het Rijnlandse model is dan ook vergelijkbaar met het Nederlandse poldermodel. Zie ook de interessante passages over Europese stedenliga's van M. Prak in diens Citizens without nations. Urban citizenship in Europe and the world, c.1000-1789, Cambridge 2018, pp.228-239.

68 H. den Heijer, 'Het recht van de sterkste in de polder. Politieke en economische strijd tussen Amsterdam en Zeeland over de kwestie Brazilië, 1630-1654', in: D. Bos, M. Ebben \& H. te Velde (red.), Harmonie in Holland, pp.72-92.

69 J. Roelevink, '1618: De internationale Nationale Synode', in: L. Heerma van Voss e.a. (red.), Wereldgeschiedenis van Nederland, pp.219-224.

70 Lendering, Polderdenken, p.94.

71 Pleij in W. Kieskamp, 'Wie tegen het poldermodel is, is tegen Nederland'; Pleij, Erasmus en het poldermodel, pp.29-30, 47. Zie ook Lendering, Polderdenken, pp.73, 79, 94.

72 M. Ebben, 'Twee wegen naar Munster. De besluitvorming over de Vrede van Munster in de Republiek en Spanje', in: D. Bos, M. Ebben \& H. te Velde (red.), Harmonie in Holland, pp.49-71, aldaar p.50. 
te maken. ${ }^{73}$ Maar historici zien geen invloed van Erasmus hierin doorwerken, maar eerder dat Willem in een luthers Duitsland opgroeide terwijl hij als Brusselse hoveling katholiek moest zijn. Zijn keuze voor een lutherse bruid, de rijke Anna van Saksen, had vermoedelijk meer te maken met haar fenomenale politieke en financiële netwerken onder de vooraanstaande protestantse rijksadel dan met gewetensvrijheid. ${ }^{74}$ Historici onderschrijven ook niet gauw de stelling dat Erasmus de 'erasmiaanse' cultuur heeft veroorzaakt: het is waarschijnlijker dat hij door een al bestaand vrij discussieklimaat beïnvloed is geweest. ${ }^{75}$

De relatief grote vrijheid van meningsuiting binnen de Republiek moeten we ook in het juiste perspectief blijven bezien. Het 'vrije woord' werd vooral aangejaagd door de Nederlandse kranten en tijdschriften die zich toelegden op de verspreiding van (politiek) nieuws. Dit had niet te maken met een overmatige neiging tot gewetensvrijheid. Elk gewest en elke stad legde immers censuur op. Zo waren de geschriften van Hugo de Groot nergens welkom, en vooral in tijden van politieke crises sloeg de overheidscontrole hard toe in de wereld van de drukpers. Het grote verschil met de andere landen in Europa was de federalistische structuur van de Republiek die de effectiviteit van censuur beperkte. Hierdoor kon het Nederlands boekenbedrijf de opgelegde regels makkelijker ontlopen. ${ }^{76}$ De decentrale en verstedelijkte structuur bepaalde de intensiteit van overleg en de relatief vrije publieke opinie. Dat had weinig te maken met een 'stil verbond' tussen de landsheer en zijn onderdanen, met gewetensvrijheid of met de invloed van een gezel in een of andere democratische wijkraad.

73 M. van Gelderen, 'De Nederlandse Opstand (1555-1610): Van vrijheden naar oude vrijheid en de vrijheid der conscientien', in: E.O.G. Haitsma Mulier en W.R.E Velema (red.), Vrijheid. Een geschiedenis van de vijftiende tot de zestiende eeuw, Amsterdam 1999, pp.27-52, aldaar p.47; J. van der Steen, 'Remembering the Revolt of the Low Countries: Historical canon formation in the Dutch Republic and Habsburg Netherlands, 1566-1621', in: Sixteenth Century Journal, 49.3 (2018), pp.713-741, aldaar pp.727, 741.

74 F. Deen, Anna van Saksen. Verstoten bruid van Willem van Oranje, Amsterdam/ Antwerpen 2018, pp.60-62.

75 G. Marnef \& A.-L. Van Bruaene, 'Civic religion: community, identity and religious transformation', in: B. Blondé, M. Boone \& A.-L. Van Bruaene (red.), City and society in the Low Countries, 110o-160o, Cambridge 2018, pp.128-161, aldaar p.151.

76 J.W. Koopmans, Early modern media and the news in Europe. Perspectives from the Dutch Angle, Leiden \& Boston 2018, pp.23-25; A. Pettegree \& A. der Weduwen, De boekhandel van de wereld. Drukkers, boekverkopers en lezers in de Gouden Eeuw, Amsterdam \& Antwerpen 2019, pp.19, 96, 110-114, 409. 


\section{Continuïteit van het poldermodel?}

Terugkerend naar de vraag, hoe het met de continuïteit van het poldermodel zat. Was er op dat gebied een duidelijk verschil te zien tussen de uitspraken in de publiekgerichte werken van Pleij en Lendering aan de ene kant en in bijdragen van academische, professionele historici aan de andere kant?

Pleij ziet het plattelandspolderen doorwerken in de stedelijke cultuur die daardoor 'no-nonsense' was, 'recht voor zijn raap', 'zonder fratsen'. Die invloed zou nog steeds bestaan. ${ }^{77}$ De 'zware traditie' van gezelligheid in de gilden is bijvoorbeeld volgens hem 'nog steeds (...) zichtbaar in het relatieve gemak waarmee in de moderne tijd werkgevers en werknemers zaken doen'. ${ }^{78}$ Ook Lendering ziet een rechte lijn. Vanuit het egaliserende waterbeheer plantte de overlegcultuur zich 'voort in de gilden, in de Statenvergadering, in de calvinistische gemeenten, Amsterdamse regentenkringen, in de verzuiling. ${ }^{79}$ Slechts twee keer werd het polderen in de Nederlandse geschiedenis 'ter discussie gesteld', namelijk tijdens de overheersing door Filips II en de Franse Tijd. Maar gelukkig was het toch gezellig aan het begin van de negentiende eeuw: er 'bleef (...) een gevoel van saamhorigheid bestaan en dat was meer dan je kon zeggen van Frankrijk of Engeland.' ${ }^{80}$ Zelfs in de tijd van de Duitse bezetting verdween het polderen niet: 'Integendeel, er heeft nooit zoveel overleg plaatsgevonden als onder de vooraanstaande Nederlanders die door de bezetters waren gegijzeld en geïnterneerd in Sint-Michielgestel.' 81

Om dit alles aan elkaar te kunnen praten, ziet Pleij mentale constructies, 'beeldvorming en collectieve mentaliteiten, die (...) eigen tradities vormen'. ${ }^{82}$ Lendering spreekt zich niet uit over collectieve mentaliteiten, maar heeft het wel over een 'culturele grammatica': 'De Nederlandse culturele grammatica wordt gedomineerd door overleg - wie daaraan zit, komt aan het hart van Nederland'. ${ }^{83}$

Prak en Van Zanden hebben een meer genuanceerde interpretatie. Volgens hen is er niet één Nederlands poldermodel: het poldermodel is juist een aantal malen

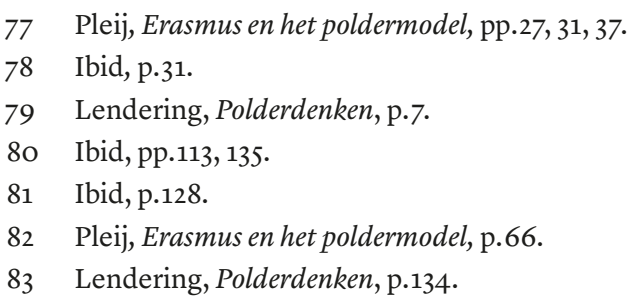


opnieuw uitgevonden. ${ }^{84}$ Maar opmerkelijk genoeg zetten zij de continuiteit toch ook uitzonderlijk zwaar aan, zoals te zien is in deze passage:

Het patroon wordt in de tijd gereproduceerd doordat (...) op microniveau mensen de regels van het maatschappelijke verkeer in een bepaalde levenshouding [incorporeren] die zij inderdaad als min of meer vanzelfsprekend ervaren: "zo doen wij dat hier nu eenmaal". ${ }^{85}$

Ook voor hen is het poldermodel dus het standaardpatroon van de Nederlanders. ${ }^{86}$

Volgens mij zijn uitspraken over collectieve mentaliteiten van een heel volk, over een culturele grammatica van een heel land, over vanzelfsprekendheden op microniveau gedurende de hele Nederlandse geschiedenis, aanleidingen om zeer kritisch te zijn. Die kritiek mag zeker verder gaan dan een bewering dat dit 'sweeping statements' zijn. ${ }^{87}$ Opmerkelijk genoeg zijn ook andere gerenommeerde academische historici niet vrij van de visie dat Nederlanders een of andere bijzondere aanleg of denkpatroon hebben, al neemt niet iedereen de term poldermodel zo makkelijk in de mond. Willem Frijhoff en Marijke Spies zien in hun standaardwerk 1650. Bevochten Eendracht een 'overlegcultuur' die al bekend was in de waterschappen. Deze kreeg tijdens de Republiek een krachtige impuls, zodat consensus 'altijd' als hoger doel werd nagestreefd, met 'een nooit en nergens aflatende, en door alle segmenten en groepen van de samenleving gedeelde discussiecultuur.' 88 In een recent essay over de Nederlandse identiteit maakt Frijhoff expliciet duidelijk dat de 'collectieve identiteit' van Nederlanders in de tijd van de Republiek zou zijn ontstaan. Deze ontwikkelde zich tot 'een collectieve zelf-perceptie' die 'heel het volk omvatte'. Daarnaast spreekt hij ook van 'de democratische habitus' als een historische verworvenheid en waarde. ${ }^{89}$ Ook Frits van Oostrom liet zich tot vergelijkbare uitspraken verleiden. Hij noemde

84 Prak \& Van Zanden, Nederland en het poldermodel, p.14.

85 Ibid, p.15.

86 Zie ook de kritiek van B. De Munck, 'Mutations to the polder model. Critical reflections on exceptionalism and continuity in the Low Countries', in: BMGN, 129.1 (2014), pp.112-124, aldaar pp.114 en 118.

87 H. te Velde, 'Het poldermodel. Een introductie', in: D. Bos, M. Ebben \& H. te Velde (red.), Harmonie in Holland, Amsterdam 2007, pp.9-29, aldaar p.24: uitspraak over Pleijs Erasmus en het poldermodel.

88 W. Frijhoff \& M. Spies, 1650. Bevochten eendracht, Den Haag 20oo, p.218.

89 Willem Frijhoff, Nederlandse identiteit in historisch perspectief, Den Haag 2019, pp.8, 21, 24. 
Nederland een 'land van regeerders in een rijtjeshuis,' waarbij het poldermodel tot onze 'diepste traditie' zou behoren. De 'echte jongens van Jan de Witt' zouden 'aartsonderhandelaars, gladstrijkers en samenwerkingsvirtuozen, coalitiesmeders, evenwichts- en draagvlakkunstenaars' zijn. ${ }^{90}$

Daarmee zijn zij het dus in feite eens met Pleij en Lendering dat de continuïteit op het gebied van de overlegcultuur uitzonderlijk sterk is. De analyse is dezelfde, ook al gebruikt de een de term grammatica en de ander habitus. Bij al deze passages zijn dezelfde vragen te stellen: doen 'we' dit echt allemaal zo? Participeren alle segmenten van de samenleving? Is er een door alle groepen gedeelde discussiecultuur? Heeft iedereen dezelfde collectieve zelfperceptie? Zijn er geen klassen, geen religieuze, regionale of etnische verschillen?

Aangeleerd gedrag, want dat is cultuur, lijkt dan op één of andere manier in de Nederlandse 'genen' te zitten. ${ }^{91}$ Het grote probleem met een dergelijke stelling is dat zij per definitie niet verifieerbaar is. ${ }^{92}$ In ieder geval zit cultuur niet in een gen. Sociale wetenschappers staan meestal kritischer tegenover dergelijke uitspraken. Visser en Hemerijck zagen bijvoorbeeld geen continuïteit in het polderen. Volgens hen was de samenwerking tussen de 'partners' in de jaren 1970 ver te zoeken. De bonden en werkgevers konden het maar moeilijk met elkaar eens worden, en de adviezen van de SER werden vaker niet dan wel opgevolgd. ${ }^{93}$ Ook Wim Blockmans stelt dat een verleden van een democratiserende politieke cultuur niet betekent dat continuïteit gegarandeerd is. Voortdurend moet de democratie opnieuw bevochten worden, al maakt het hebben van een dergelijk verleden het draagvlak daarvoor wel breder. ${ }^{94}$

De veronderstelde continuïteit van het poldermodel is daarom sterk geconditioneerd door hedendaagse kaders. ${ }^{95}$ Pleij en Lendering kozen ervoor om te focussen op één aspect, het polderen, waarschijnlijk omdat deze term zo in de mode was gekomen in de jaren 1990. Dat ook academische historici deze continuïteiten zien is even

$90 \quad$ F. van Oostrom, 'Dit is een land van regeerders in een rijtjeshuis: het leiderschap schuilt in het collectief', in: NRC Handelsblad, 6 januari 2007.

91 Benaming van E. Jonker, 'Op eieren lopen. Canonvorming met een slecht geweten', in: BMGN, 121.1 (2006), pp.76-92, aldaar p.91; Delsen, Exit poldermodel, p.9.

92 J. Leerssen, Nationale identiteit als perpetuum mobile: identiteitsbesef in permanente wording, Den Haag 2019, p.3 en Jonker, 'Op eieren lopen', p.92.

93 Visser \& Hemerijck, Een Nederlands mirakel, p.137.

94 Blockmans, Medezeggenschap, pp.406-410.

95 E. Jonker, 'Sotto voce. Identiteit, burgerschap en de nationale canon', in: Tijdschrift voor Geschiedenis 119 (2006), pp.178-195. 
recent als de opkomst van de term poldermodel zelf. Maar het verhaal van Nederland laat zich net zo goed via andere aspecten beschrijven. Het is heel goed mogelijk een continuïteit te zien in de conflictueuze geschiedenis, zoals de auteurs van Onbehagen in de polder doen. Zij klagen er terecht over dat er in Nederland minder aandacht is voor de 'articulatie van onvrede,'

(...) omdat veel historici het conflictueuze karakter van de Nederlandse geschiedenis niet op waarde hebben geschat. Het idee dat de Nederlandse samenleving in hoofdlijnen consensusgericht en harmonieus zou zijn, voert in de geschiedschrijving meestal de boventoon. ${ }^{96}$

Deze boventoon bepaalt het 'collectieve herinneren'. Maria Grever stelt echter: 'Omdat collectieve herinneringen meestal uit onderscheiden - soms met elkaar concurrerende - herinneringsculturen bestaan, kunnen we niet spreken van 'de' Nederlandse collectieve herinnering'. ${ }^{97}$ Academische historici moeten zich in ieder geval meer bewust zijn van mogelijke andere, parallelle lijnen in de geschiedenis. Het had Pleij en Lendering, en ook de hierboven aangehaalde academische historici, gesierd als ze minstens hadden aangegeven dat in de geschiedenis heel veel mensen buiten de door hen benadrukte overlegcultuur bleven. Het geprivilegieerde corporatisme, dat met de gepopulariseerde versie van het poldermodel samenhangt, gaf geen toegang tot overleg aan werkenden die buiten een gilde of vakbond vielen, aan boeren die geen grote landeigenaars waren, en ook niet aan vrouwen en migranten. Zij kregen de consensus opgelegd zonder dat zij mee konden praten.

96 P. van Dam, B. Mellink \& J. Turpijn, 'Inleiding', in: Iidem (red.), Onbehagen in de polder. Nederland in conflict sinds 1795, Amsterdam 2014, p.12.

97 M. Grever, "Visualisering en collectieve herinneringen. "Volendams meisje" als icoon van de nationale identiteit', in: Tijdschrift voor Geschiedenis 117.2 (2004), pp.207-229, aldaar p.212. 


\section{Conclusie}

Na de val van de Muur in 1989 verschenen in steeds meer landen beschouwingen over de 'eigen aard' van de nationale cultuur. ${ }^{98}$ Pleij schreef zijn boekje als aanval op de 'nationale zelfverkleining' van Nederland. ${ }^{99}$ Voor hem is en blijft het poldermodel een

uniek instrument, zeer schok- en revolutiebestendig, dat optimale betrokkenheid bij alles garandeert: een conflictmodel met de pragmatiek van een ingebouwde tolerantie, die vroeg of laat maar wel altijd naar een leefbare consensus leidt. ${ }^{100}$

De claim van uniciteit is lastig te weerleggen, omdat er maar weinig internationale vergelijkingen bestaan op dit vlak. ${ }^{101}$ Overleg en luisteren naar andere meningen lijken echter helemaal niet zo uniek te zijn. Volgens Visser en Hemerijck vertoonde het Nederlandse corporatisme bijvoorbeeld sterke overeenkomsten met dat van België, Denemarken, Noorwegen, Zweden, Zwitserland en Oostenrijk. ${ }^{102}$ Deze claim is precies wat de socioloog Frank Lechner observeerde, dat Nederlanders de neiging hebben zichzelf unieke omgangsvormen toe te dichten:

The Dutch, the story purports to show, have a distinctive way of making collective decisions. (...) In the way they run their affairs, they like to think, they continue to strive for consensus while accommodating differences.(...) [This] path-dependent, paradigmatic discourse about collective problems is a way to reimagine community. ${ }^{103}$

De zoektocht naar wat Nederlanders bindt is een begrijpelijke behoefte, maar het publieke debat daarover mondt vaak uit in een nogal anekdotisch besef van het verleden, zoals te zien is in de werken van Lendering en Pleij. 'Zo doen we dat nu eenmaal' kan, wat mij betreft, net zo goed op ploeteren slaan. Er wordt misschien wel veel gepraat,

98 M. Grever, 'Veranderende coördinaten van herinnering', in: M. Grever \& K. Ribbens, Nationale identiteit en veelvormig verleden, Amsterdam 2007, pp.61-86, aldaar pp.8o-84. Zie ook J. Leersen, Nationaal denken in Europa. Een cultuurhistorische schets, Amsterdam 1999, p.141.

99 Pleij in Wilma Kieskamp, 'Wie tegen het poldermodel is, is tegen Nederland'.

100 Pleij, Erasmus en het poldermodel, p.106.

101 Te Velde, 'Het poldermodel. Een introductie', p.25.

102 Visser \& Hemerijck, Een Nederlands mirakel, p.28.

103 Lechner, The Netherlands, pp.56, 64-65. 
maar het is niet evident dat 'we er samen meestal wel uit komen' of dat de consensus 'leefbaar' is. ${ }^{104}$ Bovendien gaat het de laatste jaren juist weer opmerkelijk minder goed met 'het polderen' in Nederland. Of Europa iets waardevols van ons kan leren, zoals Lendering stelt, is dan ook zeer de vraag. ${ }^{105}$ Het lijkt me dat academici met de statuur van Pleij en Lendering toch wat genuanceerder om dienen te gaan met de presentatie van 'het' Nederlandse verleden.

Een tijd lang was het dominante Nederlandse historische narratief 'de koopman en de dominee'. Deze is sinds de jaren 1990 langzamerhand maar zeker vervangen door het narratief van het poldermodel. ${ }^{106}$ Het kan heel goed zijn dat er heel veel overleg is in Nederland, maar net zo goed soms ook helemaal niet. Waarschijnlijk zijn de verschillen met andere landen minder scherp dan je zou verwachten. Het is in ieder geval belangrijk te beseffen dat polderen geen automatisme is, en dat de 'consensus' uiteindelijk altijd werd en wordt bepaald door degenen die de macht in handen hebben, ook in de Nederlandse geschiedenis. En als het 'de consensus' in Nederland is dat we altijd een poldermodel hebben gehad, dan kan je je ook afvragen in wiens belang die consensus is.

Marjolein 't Hart is Bijzonder Hoogleraar Geschiedenis van Staatsvorming in Mondiaal Perspectief en Senior Onderzoeker bij het Huygens Instituut voor Nederlandse Geschiedenis. Haar onderzoek richt zich vooral op de geschiedenis van politieke machtsvorming en het verzet daartegen, op oorlog en economie, op stedelijke netwerken en de rol van het geld. Zij specialiseerde zich op de Gouden Eeuw van de Nederlandse Republiek, maar schrijft ook over bredere sociale en economische processen op de lange termijn en op wereldhistorisch niveau.

104 De tekst tussen aanhalingstekens zijn (parafrases van) citaten die eerder in de tekst voorkomen.

105 Lendering, Polderdenken, p.9.

106 M. Kropman, C. van Boxtel \& J. van Drie, 'Small country, great ambitions. Prospective teachers' narratives and knowledge about Dutch history', in: Arthur Chapman en Arie Wilschut (red.), Joined-up history. New directions in history education research, Charlotte NC 2015, pp.57-84, aldaar p.62. 


\title{
De herdenkingsbeweging en de plaats van het slavernijverleden in de Nederlandse identiteit
}

\author{
Karwan Fatah-Black
}

\begin{abstract}
In Nederland wordt het gesprek over het slavernijverleden op tal van plekken gevoerd, variërend van de lokale historische kring en welzijnsorganisaties tot aan de universiteiten en het parlement. Publicaties van nieuwe boeken en tijdelijke tentoonstellingen in musea geven met regelmaat nieuwe stof voor opinieartikelen in dag- en weekbladen die op hun beurt een belangrijk referentiepunt zijn voor het onderwijs, de politiek en op sociale media. Het debat wordt soms gezien als gepolariseerd en een splijtzwam in de samenleving. In dit essay betoogt Karwan Fatah-Black dat dat niet het geval is. Hoewel er een luidruchtige minderheid is die het slavernijverleden politiseert, lijkt de herdenkingsbeweging van nazaten juist gericht op inclusiviteit en verzoening. Concrete publiekshistorische projecten die de aandacht hebben gevestigd op onverwachte verbanden tussen de hedendaagse samenleving en het slavernijverleden dragen juist op een positieve manier bij aan maatschappelijke consensus. De herdenkingsbeweging fungeert in dat proces als inspirator en aanjager.
\end{abstract}

\section{Weerstand tegen de publieke herdenkingscultuur}

$\mathrm{H}$ istoricus Willem Frijhoff stelt in een essay voor het Sociaal en Cultureel Planbureau dat nationale identiteit een optelsom is van de onderwerpen waarover Nederlanders hevig van mening verschillen. ${ }^{1}$ Volgens die definitie is de geschiedenis van slavernij onbetwistbaar een deel van de Nederlandse identiteit. Er is nog altijd

1 W. Frijhoff, 'Nederlandse identiteit in historisch perspectief', in: Denkend aan Nederland: Sociaal en Cultureel Rapport 2019, Den Haag 2019. 
onenigheid over de vraag hoe we dit verleden een plek geven en in hoeverre het belangrijk is om deze geschiedenis te gedenken. Het slavernijverleden is een van de slagvelden geworden waar de vraag lijkt te worden uitgevochten wat onder Nederlands burgerschap en Nederlanderschap verstaan wordt. De definitie van Frijhoff is erg afstandelijk en relativerend. Dat het slavernijverleden een plek in het Nederlandse geschiedverhaal heeft is immers geen gegeven, maar op zichzelf omstreden. Er zijn onmiskenbaar pogingen om het slavernijverleden terug naar de marges van de nationale geschiedenis te duwen of zelfs actief te vergeten. Dergelijke pogingen tot silencing karikaturiseren vaak de roep vanuit de gemeenschap van nazaten om opgenomen te worden in de Nederlandse natie. Pogingen tot inclusie worden geridiculiseerd of worden voorgedaan als aanvallen op nationale trots. In 2008 pleitte Rita Verdonk in haar speech bij de lancering van haar partij Trots op Nederland tegen een 'weg-metons'-cultuur en tegen nieuwe slavernijmonumenten. ${ }^{2}$ Sindsdien duikt de frase 'wegmet-ons' regelmatig op. Twaalf jaar na Verdonk gebruikt Forum voor Democratie nog altijd vrijwel identieke bewoordingen om datzelfde punt te maken. ${ }^{3}$

Onder historici is in uitzonderlijke gevallen ook een dergelijk geluid te signaleren. De Leidse emeriti Piet Emmer en Henk den Heijer maakten in 2019 een nieuw monument ter herdenking van de afschaffing van de slavernij het mikpunt van sarcastische kritiek. ${ }^{4}$ In Hoofddorp werd door de Gemeente Haarlemmermeer in 2018 een monument neergezet ter herdenking van de afschaffing van de slavernij. In een essay voor

2 'Om te beginnen is er een sterke "weg-met-ons" stroming die ons al jaren wil doen geloven dat onze cultuur niet bestaat en die onze waarden en normen zelfs minderwaardig vindt ten opzichte van andere culturen. Ze stellen zelfs het sinterklaasfeest ter discussie. En willen overal slavernijmonumenten om ons als slecht af te schilderen.' R. Verdonk, 'Speech bij de oprichting van Trots op Nederland, 3 april 2008, https://docplayer.nl/13209203-Speech-rita-verdonk-passenger-terminal-amsterdam-3-april-2008.html (geraadpleegd 2 september 2020).

3 Cultuurbeleid van de partij Forum voor Democratie: 'Op dit moment subsidieert de Nederlandse overheid segregatie-bevorderende, weg-met-ons projecten; terwijl we datgene waar we trots op mogen zijn, het mooiste en het beste dat het Westen heeft voortgebracht, onderschoffelen.', https://forumvoordemocratie.nl/standpunten/ cultuurbeleid (geraadpleegd 21 februari 2020).

4 P. Emmer \& H. den Heijer, 'Schuldig verleden? Discussie slavernijverleden in ideologisch vaarwater', in: Elsevier Weekblad (2019), https://www.elsevierweekblad. $\mathrm{nl} /$ nederland/achtergrond/2019/05/schuldig-verleden-173626w/ (geraadpleegd $2 \mathrm{O}$ februari 2020). 
het weekblad Elsevier schamperen Emmer en Den Heijer dat Haarlemmermeer niets met slavernij te maken had:

Maar waarom heeft de gemeente Haarlemmermeer afgelopen jaar een slavernijmonument geplaatst? Ten tijde van de slavernij was daar een meer, een watervlakte. Hoe 'schuldig' is een meer? Moeten er ook slavernijmonumenten in de Noordoostpolder en de Wieringermeer worden geplaatst - of erger nog, in zee? 5

In de passage koppelen ze het plaatsen van een monument aan de 'schuldigheid' van een plek, niet aan de behoefte van de gemeenschap van nazaten. Uit niets is echter op te maken dat enige vorm van beschuldiging de aanleiding is voor het monument. Het ging erom dat er een gemeenschap van nazaten al jaren in die gemeente ijverde voor een plek ter contemplatie. Elaine Veldema van Participatieteam Haarlemmermeer, zelf nazaat, wilde graag de mogelijkheid creëren om rustig tussen de bomen en het liefst aan het water te kunnen reflecteren op het verleden. Het ridiculiseren van het monument, zonder de nazaten zelf aan het woord te laten of hun beweegredenen serieus te nemen past binnen een ideologisch project zoals dat de afgelopen jaren door Rita Verdonk, Geert Wilders en Thierry Baudet in de landelijke politiek is verwoord.

De weerstand tegen monumenten ter herdenking van de afschaffing van de slavernij en het gebruik van de bewoording 'weg-met-ons' suggereert dat degenen die vragen om erkenning geen deel zijn van die 'ons'. De frase is bovendien niet een directe bestrijding van nazaten die vragen om erkenning, maar een aanklacht tegen een deel van 'ons' die er de verkeerde mentaliteit op nahoudt. De suggestie is dat een deel van 'ons' niet trots genoeg is en daarom toelaat dat een ander (in dit geval Afro-Nederlanders) ons de wetten voorschrijft. Dergelijke vijandigheid tegen culturele, etnische en zelfs raciale diversiteit vormt een consistente stroming in het Nederlandse politieke vertoog over de nationale identiteit. Verzet tegen een bedachtzame omgang met het slavernijverleden die ruimte biedt voor een gelaagd beeld van dat verleden stuit op een theatrale weerstand bij politieke stromingen die een exclusieve Blanke politieke identiteit lijken vorm te willen geven. In Nederland is er een ambigu antwoord op 
de vraag of staatsburgerschap dan wel etniciteit de basis is voor Nederlanderschap. ${ }^{6}$ Deze ambiguiteit biedt ruimte voor politieke stromingen om te appelleren aan een exclusief etnische politieke identiteit rond het idee van Blank exceptionalisme. De vorming van deze identiteit moet het hebben van het contrast tussen een Blanke identiteit en die van gekarikaturiseerde minderheden, zoals moslims en Afro-Nederlandse nazaten van slaafgemaakten. De nazaten-die zelf nauwelijks aan het woord komen-wordt verweten de rest van de samenleving een schuldgevoel aan te praten en trots te willen vervangen door schaamte.

\section{De gemeenschap van nazaten op het nationale toneel}

Wie naar de uitingen van de herdenkingsbeweging kijkt kan met geen mogelijkheid tot de conclusie komen dat het hier gaat om een 'weg-met-ons'-stroming. Dat is voor het bredere publiek echter moeilijk vast te stellen zolang deze beweging zelden zelf aan het woord komt. Op 1 juli 2002 werd in het Amsterdamse Oosterpark het monument ter herdenking van de afschaffing van de slavernij onthuld. De onthulling van het monument kwam 139 jaar na de afschaffing van de slavernij. Veel van de nazaten van de voormalige slaven die in 1863 vrij waren verklaard zijn in de jaren '7o en '8o naar Nederland gekomen. Zij en degenen aan wie zij hun verhalen en herinneringen doorgaven zijn belangrijke dragers van publiek bewustzijn van de slavernijgeschiedenis. In zijn onderzoek naar postkoloniaal Nederland stelt historicus Gert Oostindie: 'De Atlantische slavenhandel en slavernij zijn nooit vergeten. Herinneringen, allengs meer gestileerd, vervormd en gecanoniseerd, zijn van generatie op generatie door de nazaten doorgegeven. ${ }^{7}$ De nazaten ontwikkelden een maatschappelijke beweging van diverse organisaties om de geschiedenis van slavernij in Nederland erkend te

6 M. Schrover, 'Pillarization, Multiculturalism and Cultural Freezing. Dutch Migration History and the Enforcement of Essentialist Ideas', in: Bijdragen en Mededelingen betreffende de Geschiedenis der Nederlanden, 125.2-3 (2010), pp.329-354 en C. Laarman, Oude onbekenden: het politieke en publieke debat over postkoloniale migranten, 1945-2005, Hilversum 2013, p.157.

7 G. Oostindie, Postkoloniaal Nederland: vijfenzestigjaar vergeten, herdenken, verdringen, Amsterdam 2010, p.163. 
krijgen, zowel bij de overheid en in het onderwijs als in de samenleving als geheel. ${ }^{8}$ Men hoopte dat dit zou leiden tot een insluiting van Afro-Nederlanders als een onlosmakelijk deel van de Nederlandse natie. ${ }^{9}$ Overigens was de beweging van nazaten divers: het meest zichtbare deel was uit op politieke erkenning, maar een ander deel richtte zich op bewustwording binnen de eigen gemeenschap. Die bewustwording verhield zich moeizaam tot de wens om erkenning, die immers contact met een soms onbegrijpende buitenwereld met zich meebracht.

Ook degenen die hoopten op insluiting bleven botsen op de politieke en maatschappelijke realiteit in Nederland. De onthulling van het monument bevestigde bij velen dat er nog altijd op ze werd neergekeken en dat ze nog altijd minderwaardig en onmenselijk werden behandeld. Tijdens de onthulling in 2002 kwam het namelijk tot een onbedoelde maar directe confrontatie tussen de gemeenschap van herdenkers en de hoogste politieke niveaus. De onthulling, minder dan een jaar na de aanslagen in de Verenigde Staten van 11 september 2001, vijf maanden na de grootse herdenking van 400 jaar VOC en twee maanden na de moord op de Nederlandse politicus Pim Fortuyn, werd nerveus beveiligd en was alleen toegankelijk voor genodigden. Terwijl de toenmalige koningin Beatrix, haar zoon en huidige koning Willem-Alexander, premier Wim Kok, diverse ministers en de Amsterdamse burgemeester Job Cohen bij de onthulling waren werden nazaten met geweld op afstand gehouden. ${ }^{10}$ Op de beelden van die dag zien we bij degenen die kwamen herdenken zowel verwarring, frustratie als volharding. ${ }^{11} \mathrm{Na}$ het arriveren van de koningin en haar gevolg horen we nog 'oh' en 'ah' en uitroepen van bewondering, maar al snel na het uitstappen uit de dienstauto en tijdens de wandeling naar het monument verandert de sfeer en begint boe-geroep en gejoel. Op een videoverslag van de dag zien we een vrouw die roept 'We gaan naar huis, omdat wij geen zeggenschap hier hebben. We moeten wachten tot de koningin het heeft gehuldigd.' De vrouw vervolgt haar betoog waarin ze uitdrukking geeft aan de onrechtvaardigheid van de situatie en haar weerzin tegen de zichtbare en voelbare ongelijkheid: 'Maar ik ben ook een koningin, ik ben de koningin van Suriname. Mag

8 A. Sens, 'The "Veil" in Post-Slavery Society. New Challenges for Historians: The Case of Surinam, 1808-2008', in: M. van der Linden (red.), Humanitarian Intervention and Changing Labor Relations. The Long-term Consequences of the Abolition of the Slave Trade, Leiden 2011, pp.69-114.

9 Oostindie, Postkoloniaal Nederland, p.168.

10 'Chaos bij onthulling slavernijmonument', De Volkskrant, 2 juli 2002.

11 F. Buis, Rellen bij onthulling Slavernijmonument door Koningin Beatrix (2014), https:// www.youtube.com/watch?v=LEIugXqOwfY\&t=206s (geraadpleegd 20 februari 2020). 
ik daar niet staan? (...) In Suriname hebben we ook een koningin, toch? Waarom moet het alleen Beatrix zijn?' Ze doet een uitspraak die die dag en ook later nog vaak te horen zal zijn: 'Wij zijn toch ook Nederlanders?'12

Een andere aanwezige verwoordt de spanning tussen nationale erkenning door de aanwezigheid van de koningin en de uitsluiting bij de onthulling nog duidelijker:

Dit is een Surinaamse dag, dag van de emancipatie. En mogen wij niet naar binnen? Het is ons feest. Onze voorouders zijn slaven geweest. Volgens mij was de koningin, het koningshuis daarvoor verantwoordelijk. En nu is zij hier. En omdat zij hier is mogen wij niet naar binnen. Ik heb zoiets nooit bedacht. Dit is echt een vorm van dat de slavernij nog niet voorbij is. Het bestaat nog steeds en de zwarte organisatoren die verantwoordelijk zijn die noemen we basja's [slavenopzichters], die noemen we redi musu's [roodmutsen, zwarte soldaten die voor de kolonie vochten tegen opstandelingen], die waren de verraders. Dat vind ik er van. Ik vind het zo belachelijk. Dit is de zwartste dag van mijn leven. ${ }^{13}$

De aanwezigen lijken verdeeld over hoe ze op deze situatie moeten reageren. Een vrouw doet de oproep 'Laten we naar huis gaan. Katibo [slaven], ik voel mij niet vrij.' Dat is echter niet wat de herdenkers zullen doen. Omstanders bij de hekken roepen 'We gaan naar binnen', 'Laat ons er in', 'Haal de hekken weg.' Men kan het monument, waar zolang naar is uitgekeken, niet de rug toekeren. Men blijft staan en praten met de agenten. Hekken worden omvergetrokken en er wordt geprobeerd om toch toegang te krijgen tot de onthulling. De nazaten benoemen expliciet dat er een continuïteit is tussen hun uitsluiting op dat moment en de geschiedenis van slavernij. Om uitdrukking te geven aan hun hoop op een gelijkwaardige toekomst zingen de aanwezigen We shall overcome. ${ }^{14}$ Het lied is een verwijzing naar de strijd van nazaten in andere delen van de Afro-Atlantische diaspora en een verwijzing naar de strijdmethoden van broeders en zusters elders.

Tijdens de onthulling van 1 juli 2002 werden de tegenstellingen zichtbaar tussen het belang van het doorgeven van de geschiedenis van slavernij als fundamenteel onderdeel van de eigen identiteit en de wens hiervoor ook op nationaal en politiek niveau erkenning te krijgen. Een kleine 140 jaar lang hadden voormalige slaven en hun

$\begin{array}{ll}12 & \text { Ibid. } \\ 13 & \text { Ibid. } \\ 14 & \text { Ibid. }\end{array}$ 
nazaten in eigen kring deze geschiedenis herdacht. Ze waren in de Nederlandse publieke ruimte goeddeels afwezig geweest en hadden geen ruimte op een landelijk podium opgeëist. $\mathrm{Nu}$ er publieke erkenning begon te komen voor het slavernijverleden werd het onderwerp op hoger politiek niveau relevant en een prominenter deel van het publieke debat. Landelijke politici hebben en hadden andere belangen en prioriteiten dan de herdenkers. Dat werd pijnlijk duidelijk bij de onthulling van het monument. Het NiNsee (Nationaal Instituut Nederlands Slavernijverleden en Erfenis) was zozeer bezig met, in hun ogen, het faciliteren van de hoogwaardigheidsbekleders (wiens aanwezigheid van groot belang was voor het verwerven van nationale erkenning) dat men vergeten was ruimte te maken voor de gemeenschap die om die erkenning vroeg. Maar er waren ook belangrijke inhoudelijke verschillen in benadering tussen de gemeenschap en de politiek. Uit de speech van minister Roger van Boxtel (D66), sprak dit duidelijke verschil. Waar de herdenkers erkenning wilden van hun unieke plek in de samenleving, had de speech van Van Boxtel een 'dit nooit weer'-boodschap die gericht was op hedendaagse vormen van dwangarbeid. Waar herdenkers vroegen om erkenning en bestrijding van racisme, spraken politici liever over het voorkomen en bestrijden van uitbuiting in het heden.

Sinds dit pijnlijke moment veranderde er veel. Enkele jaren na de onthulling in 2002 werd de geschiedenis van slavernij opgenomen in de Canon van Nederland. Zo werd de weg vrijgemaakt voor behandeling van het onderwerp in het basisonderwijs. Zo obscuur als deze geschiedenis tien jaar eerder nog was geweest, zo prominent werd het in het publieke debat in de jaren na de oprichting van het monument. Op politiek niveau kwam er meer ruimte voor lokale herdenkingen en inmiddels zijn er naast het monument in Amsterdam ook slavernij-gerelateerde monumenten in Winschoten, Ouderkerk, Hoofddorp, Rotterdam, Middelburg, Utrecht, Sassenheim en zijn er gesprekken over een monument in Den Haag.

$\mathrm{Na}$ de onthulling van het monument in 2002 en het opnemen van deze geschiedenis in de Canon van Nederland diende zich in 2013 een crisis aan. Hoewel de herdenking van 2013 groots van opzet was, met aanwezigheid van Willem-Alexander en Máxima die zich vrij door het toegestroomde publiek bewogen, kondigde de regering dat jaar ook aan dat de subsidie voor de herdenking en het NiNsee, zoals van zoveel culturele instellingen in die jaren, beëindigd zou worden. Op 1 juli 2014 intervenieerde een jonge groep activisten rond het New Urban Collective (een organisatie van studenten en jonge professionals met een niet-westerse migratieachtergrond) in de herdenking en maakten zij het vicepremier Lodewijk Asscher het spreken onmogelijk door een statement voor te lezen op het moment dat hij zou spreken. Asscher, die op 
het podium stond, stopte na de eerste woorden. Sylvana Simons, op dat moment in haar hoedanigheid als dagvoorzitter, maande de activisten eerst nog tot stilte maar zag dat het tegenover een doelgerichte en goed georganiseerde groep met een megafoon onbegonnen werk was.

De protestspeech opende met een verwijzing naar de voorouders in de Afro-Atlantische diaspora die gestreden hadden tegen slavernij, zowel binnen als buiten het Nederlandse rijk. ${ }^{15}$ De opening werd getekend door dezelfde spanning tussen de wens voor nationale erkenning en de wens controle te houden over de betekenis en invulling van de herdenking:

Wij staan hier vandaag met het grootst mogelijke respect en eerbied voor onze voorouders. Wij staan hier voor Anton, Boni, Tula, Baron, Sophie, Joli-coeur, Tata, Karpata, Toussaint, Nanny en de talloze onzichtbare strijders en slachtoffers van de Nederlandse rijkdom en welvaart. Wij zijn hier om ervoor te zorgen dat er geen vreemde adem hun herdenking betreedt. Minister Lodewijk Asscher vertegenwoordigt de Nederlandse regering: dezelfde regering die de zwarte gemeenschap respectloos behandelt, geen nationale herdenking wil, VN-verdragen naast zich neerlegt en zich niets aantrekt van de pijn en zorgen van de zwarte gemeenschap. Wij zijn hier vandaag om te voorkomen dat vicepremier Lodewijk Asscher namens de Nederlandse regering onze voorouders nog langer beledigt met loze woorden. En al helemaal niet op de dag dat wij hun strijd en leed herdenken. Alleen een zwak volk laat zo'n vernedering toe. Wij zijn niet zwak. ${ }^{16}$

Asscher was niet de eerste minister die vanwege gevoerd beleid tijdens de herdenking mikpunt werd van kritiek. Rita Verdonk werd het spreken onmogelijk gemaakt toen zij namens de regering Balkenende kwam spreken, niet lang na de invoering van strenge controles voor Surinamers op Schiphol door haar Ministerie van Justitie.

De protestspeech van juli 2014 was ambigu over de eigen identificatie. De uitspraak 'wij zijn geen zwak volk' wekt de indruk dat men zich los van de Nederlandse samenleving definieert, maar net als bij de onthulling van 2002 bleek het hoofddoel

15 Speech gehouden tijdens keti-koti in het Oosterpark in Amsterdam op 1 juli 2014. Tijdens de speech werd de tekst uitgedeeld. Een exemplaar is in het bezit van de auteur. 'Genoeg = Genoeg, wij eisen respect' - 141/151 Keti Koti 1 juli 2014 protest speech @ Oosterpark, https://www.youtube.com/watch?v=BX33 $\mathrm{N}_{5} \mathrm{ICuj} 8 \mathrm{k}>$ (geraadpleegd 26 februari 2020).

16 Ibid. 
volwaardig deel te worden van Nederland. In de speech verbonden de activisten de erkenning van het verleden met de achterstelling in het heden:

Alledaags racisme, discriminatie en uitsluiting zijn aan de orde van de dag en zorgen voor structurele ongelijkheid op de arbeidsmarkt en in het onderwijs. De keiharde cijfers liegen er niet om en vertellen ons het verhaal over schooluitval, over achterstand op de arbeidsmarkt, over armoede, over bestuurders op scholen en universiteiten, over een discriminerend politiekorps, over aanhoudende meldingen van racisme en ga zo maar door. ${ }^{17}$

De activisten plaatsen zich expliciet in een continuïteit tussen het koloniaal verleden en het heden, maar uiten ook hun onvoorwaardelijke eis om Nederlander te kunnen zijn: 'Een status-quo vol scheve verhoudingen geërfd uit een koloniale tijd mogen we niet doorgeven aan onze kinderen, Nederlandse kinderen.' De geschiedenis en het heden zijn voor de activisten onlosmakelijk verbonden:

Laat Nederland daar openlijk afstand van nemen. Hoe doe je dat? Niet alleen met excuses, spijt en berouw, maar óók met daden. En als de meerderheid in Nederland niet in staat is om te vechten voor een harmonieuze samenleving, zullen wij het zelf moeten doen. Wij moeten daadkrachtig optreden totdat Nederland de plicht op zich neemt om net zoveel aandacht te schenken aan het gedeeld verleden als alle andere traumatische verledens. ${ }^{18}$

De erkenning van deze geschiedenis heeft als doel de gemeenschap van nazaten deel te laten worden van Nederland: 'Wij zijn Nederlanders net als iedere andere Nederlander en we eisen met hetzelfde respect behandeld te worden.' Deze groepontegenzeggelijk het meest uitgesproken en felst als het gaat om de noodzaak het slavernijverleden deel te maken van de Nederlandse identiteit-lijkt geen ander doel na te streven dan volwaardig Nederlanderschap.

Hoewel de speech van 2014 een moment van crisis leek, behandelden de drie betrokken partijen (actievoerders, herdenkingsorganisatie en minister) elkaar met respect. De minister kende zijn plaats en probeerde niet de speech te onderbreken. In plaats daarvan kwam hij van het podium af om na het uitspreken van de protestspeech

17 Ibid.

18 Ibid. 
een gesprek op gelijke voet mogelijk te maken. De enige betrokkene die hier wellicht in de problemen was waren de officiële organisatoren van de herdenking, wier positie rustte op het vertegenwoordigen van de gemeenschap, wat zij op dat moment niet konden waarmaken. De groep activisten daagde hun rol als vertegenwoordigers van de gemeenschap uit. Doordat de activisten na de protestspeech weggingen bij de herdenking kwam dit echter niet tot een directe confrontatie. Sinds 2014 is de herdenking van het slavernijverleden meer en meer een lokale aangelegenheid geworden. Daarmee komen de spanningen die op nationaal niveau bestonden vaker terecht bij lokale gemeenschappen en politici met ieder hun eigen agenda's. Zowel op het landelijke als op het lokale niveau blijkt het grootste deel van de gemeenschap van nazaten gericht te zijn op insluiting van de gemeenschap in Nederland, en niet op een terugtrekken in eigen kring. Het lijkt er dus op dat er geen 'weg-met-ons cultuur' bestaat, of althans, dat de herdenkingsbeweging niet op die manier geduid kan worden.

\section{Toekomst: de geschiedenis van onze voorouder}

Er lijkt bij het Nederlandse publiek een groeiende behoefte aan wetenschappelijk onderzoek en historische duiding van dit verleden, juist ook als de uitkomsten van het onderzoek het beeld van de geschiedenis complexer en gelaagder maken. In het najaar van 2018 publiceerde ik het boek Eigendomsstrijd over het ontstaan van de vrije Afro-Surinaamse gemeenschap aan de rand van Paramaribo. ${ }^{19}$ In het boek schets ik hoe, ondanks het geweld en de uitsluiting in de door slavernij en racisme gekenmerkte samenleving, het toch mogelijk was om in de marges van die samenleving een mate van vrijheid te bevechten. Dat betekende deels een accommodatie met het slavernijsysteem. Het boek gaat uitdrukkelijk niet over heldhaftig verzet, maar juist over meebuigen en overleven. Wie een strak schema van goed en fout hanteert zal zeggen dat het boek gaat over 'collaborateurs' en 'verraders'. Het boek geeft echter geen uitgesproken oordeel en laat volgens recensent Elma Drayer 'de bronnen spreken'. ${ }^{20}$ Het geweld, de sterfte en psychische terreur die de slavensamenleving kenmerkten bleven op de achtergrond. Eigendomsstrijd wijkt welbewust af van mijn gebruikelijke

19 K. Fatah-Black, Eigendomsstrijd: de geschiedenis van slavernij en emancipatie in Suriname, Amsterdam 2018.

20 E. Drayer, 'Eigendomsstrijd biedt een mooie aanvulling op de geschiedschrijving over het slavernijverleden (drie sterren)', in: De Volkskrant, 23 november 2018. 
publicaties: het is betaalbaar, in het Nederlands geschreven, bij een commerciële uitgever verschenen en verhalend van opzet. Dat is een wereld van verschil met de Engelstalige papers voor wetenschappelijke tijdschriften die de norm zijn geworden aan de universiteit. Het boek was er op gericht om inzicht te geven in de werking en complexiteit van een slavensamenleving.

Of ik in mijn opzet ben geslaagd is moeilijk te zeggen, maar ik was positief verrast door een klein aantal nazaten die mij per post en email korte brieven over het boek stuurden. De brieven deden me beseffen hoe dichtbij deze geschiedenis in hun beleving nog altijd is. De brieven bespreken steevast de generationele afstand tot de slavernij, zoals een over-overgrootvader die in 1879 de plantage kocht waarop hij nog als slaaf had gewerkt. Of een andere briefschrijfster wier familiegeschiedenis begint bij een overgrootvader die uit Duitsland naar Suriname vertrok en daar kinderen verwekte bij een slaafgemaakte vrouw. De late leeftijd waarop de mannen in haar stamboom vervolgens zonen kregen maakt dat zij nog dicht bij dit verleden staat:

Mijn grootvader is in slavernij geboren. Nooit gekend, maar wel in ons archief een foto met andere familieleden. Mijn vader staat er niet op, hij was nog niet geboren. $\mathrm{Hij}$ is van 1891. In jouw uitleg net begrijp ik dat mijn vader en de familie X [naam bij de auteur bekend] tot de elitegroep behoorde. (...) Ik moet je eerlijk vertellen, dat toen jij dit alles vertelde ik er tranen van kreeg, steeds geëmotioneerd raakt bij het lezen en horen hoe de dingen zijn gegaan. ${ }^{21}$

De briefschrijfster realiseert zich dat de tochtjes die zij als kind maakte naar de oude plantages zijn geweest. Een andere, eveneens genealogisch geïnteresseerde nazaat was verheugd dat de 'massa losse feiten en feitjes' die in de loop der jaren over de familie waren verzameld door het boek van context werden voorzien: 'De inhoud van uw boek heeft me dus geraakt, anno 2018 voelde ik zelfs enige trots op hun strijd en prestatie.'22 $\mathrm{Nu}$ was het opwekken van warme gevoelens niet het doel van het boek, maar het is relevant dat een boek dat de complexiteit en gelaagdheid van dit verleden belicht, ook onder directe nazaten in goede aarde kan vallen. Overigens was niet iedereen enthousiast. Er werd mij, niet geheel ten onrechte, in enkele passages een 'witte blik' verweten. Ik had me, aldus Ditter Blom, niet genoeg afgevraagd wat de overwegingen en strategieën van de slaafgemaakten en gemanumiteerden (mensen die

$21 \quad$ Email ontvangen op 7 oktober 2018.

22 Email ontvangen 27 november 2018. 
door de eigenaar werden vrijgelaten) nu eigenlijk waren geweest, en zou te achteloos hebben aangenomen dat zij de koloniale hiërarchie accepteerden en respecteerden. ${ }^{23}$

Het is ontegenzeggelijk tijd voor het bedaren van de geagiteerde toon waarop gediscussieerd wordt over de vraag of de geschiedenis van slavernij een plek moet krijgen in het nationale zelfbeeld. Meer dan we wellicht begrijpen heeft de zelfidentificatie van witte Nederlanders als 'blanken' anti-zwarte en racistische betekenissen. Het verrichten van cultureel en historisch zelfonderzoek geeft de mogelijkheid om afstand te nemen en kan een louterende werking hebben. Onderwijskundig consultant Ellen-Rose Kambel ging op zoek naar de nazaten van degenen die in 1863 bij de afschaffing van de slavernij compensatie hadden gekregen voor het vrijlaten van haar voorouders. Tijdens haar zoektocht stuitte ze op de familie Charbon. ${ }^{24}$ Deze familie had haar overgrootvader in eigendom gehad. Documentaire maker Ida Does volgde Kambel bij het contact leggen met de familie Charbon. Samen bekeken de nazaten van eigenaar en eigendom de papieren die aantoonden dat er compensatie was ontvangen voor een vifftal particuliere slaven, waaronder voorouders van Kambel. De Charbons vaarden wel in de negentiende eeuw. In Sassenheim is er nabij hun voormalige buitenhuis een straat naar hen vernoemd. Hoewel hun huis er niet meer is, is de destijds aangelegde siertuin inmiddels een stadspark geworden. Met de historische kring Sassenheim werd een afgeladen bijeenkomst georganiseerd waar beide kanten van het verhaal ruimte kregen. De stichting die het stadspark onderhoudt besloot een bord te plaatsen in het park met daarop de naam van een van de plantages die bij de Charbons in eigendom was geweest. Voor de Charbon-kant was het zichtbaar ongemakkelijk zich tot deze geschiedenis te verhouden. Het ontbreekt in Nederland nog aan een taal en repertoire van handelen waarmee dit verleden op een betekenisvolle manier verwerkt kan worden.

23 D. Blom, 'Slavernij in het frame van eigendomsstrijd | blog', https://werkgroepcaraibischeletteren.nl/slavernij-in-het-frame-van-eigendomsstrijd/ (geraadpleegd 26 februari 2020); Idem, 'Witte beeldvorming in slavernijkritiek | blog', https://werkgroepcaraibischeletteren.nl/witte-beeldvorming-in-slavernijkritiek/ (geraadpleegd 26 februari 2020).

24 E.-R. Kambel, 'Slavernij in de familie: Van bewustwording naar erkenning tot verbintenis', in: Nederlands Tijdschrift voor de Mensenrechten-NJCM-Bulletin, 43:3 (2018) 459-465. 
In 2019 organiseerde Museum van Loon de tentoonstelling Aan de Surinaamse grachten. De familie Van Loon plaatste vroeg in de zeventiende eeuw twee zwarte hoofden in hun familiewapen. De achtergrond daarvan is nog onopgehelderd, maar in de eeuwen die volgden raakten de Van Loons betrokken bij slavenhandel, koloniaal bestuur en de plantage-economie. Deze kant van de familiegeschiedenis was echter nooit onderwerp van onderzoek geworden. In de tentoonstelling werden beelden getoond van de gesprekken tussen nazaten. Net als bij Kambel was ook dit geen gemakkelijk gesprek. We zien een witte man die zegt dat hij niet voelt dat hij voordeel heeft gehad aan de erfenis van deze geschiedenis. Ook hij heeft 'altijd hard gewerkt' om te komen waar hij is gekomen. De zwarte vrouw naast hem zegt ' $\mathrm{ik}$ heb ook altijd hard gewerkt, maar krijg daar niet het zelfde voor'. 'Ja, dat is zo' antwoordt de witte man. Ondanks het ongemak komt het tot een wederzijdse erkenning. Het is een gesprek, geen debat, en daar heeft het museum bewust voor gekozen. Museumdirecteur Gijs Schunselaar stelde

we kunnen het verloop van de geschiedenis niet veranderen, maar hoe we daar met z'n allen mee omgaan wél. Wat mij betreft is onderdeel daarvan dat we bereid zijn in ons museum vele verhalen te vertellen, óók de ongemakkelijke. Wanneer we dat bovendien qua perspectiefkeuze zo volledig mogelijk doen, denk ik dat we kunnen voldoen aan iets waar grote behoefte aan is: erkenning van stemmen uit de geschiedenis die tot nu toe te weinig gehoord zijn. Dat is overigens niet 'de geschiedenis van de ander', het is ónze gezamenlijke geschiedenis. Het lijkt mij logisch om op die manier met geschiedschrijving om te gaan. ${ }^{25}$

Een volgende stap werd in 2020 gezet door Maartje Duin en Peggy Bouva die in een achtdelige podcast De plantage van onze voorouders opzoek gingen naar hun gedeelde slavernijverleden, waarbij zij de moeilijke gesprekken met hun beide families en elkaar niet uit de weg gingen.

Het herstellen van de band tussen herdenkers en historici kan, zo laat de praktijk zien, een bijdrage leveren aan het definiëren van het nieuwe 'wij'. In zijn Daendelslezing van 2018 vatte Gert Oostindie het als volgt samen: 'Ik zou willen dat de bespreking van deze geschiedenissen aanleiding gaf tot het reflecteren op het pijnlijke contrast ervan met het rooskleurige zelfbeeld dat Nederland zo gretig heeft gekoesterd.

25 S. Zürcher, 'Directeur Museum Van Loon: 'Ook het ongemakkelijke verhaal moet verteld', in: Het Parool 7 mei 2019. 
Maar ik zou ook hopen dat aan dit verhaal een verbindende draai kan worden gegeven.' ${ }^{26}$ De beweging die jarenlang zowel lokaal als landelijk het slavernijverleden op de agenda heeft gezet is geen splijtzwam, maar de inspiratie voor het stellen van nieuwe historische vragen en de vorming van een inclusievere Nederlandse identiteit.

Karwan Fatah-Black promoveerde in 2013 aan de Universiteit Leiden met een proefschrift over handel en scheepvaart rond Suriname in de achttiende eeuw. Als universitair docent is hij betrokken bij onderzoek en onderwijs over vroegmoderne Atlantische geschiedenis. Hij is actief betrokken bij erfgoedinstellingen die nieuwe manieren zoeken om het slavernijverleden een plek te geven in het beeld van de Nederlandse geschiedenis. 


\title{
Spiegels van Sophia
}

\section{Geleerdenportretten en de verbeelding van vrouwen als wetenschappelijke autoriteit: een historische kadering ${ }^{1}$}

\author{
Lieke van Deinsen
}

\begin{abstract}
Gender(on)gelijkheid in de academische sector staat hoog op de agenda. Kritiek op de stereotiepe beeldvorming van de wetenschapper als man neemt toe. Vaak wordt hierbij gewezen naar de negentiende eeuw als bakermat van deze hardnekkige beeldvorming. Lieke van Deinsen betoogt echter in deze bijdrage dat ook in de vroegmoderne tijd heersende sociaal-maatschappelijke verwachtingspatronen en associaties bepaalden hoe er naar vrouwelijke geleerden werd gekeken. Ze laat zien hoe portretkunst een belangrijke rol speelde in deze beeldvormingskwestie.
\end{abstract}

$\mathrm{V}$ rouw aan de muur' kopte het NRC Handelsblad op 8 maart 2016. ${ }^{2}$ De krant deed verslag van een opmerkelijke make-over die de Senaatszaal van de Universiteit Leiden had ondergaan ter gelegenheid van Internationale Vrouwendag. Op initiatief van Athena's Angels, een collectief van vier vrouwelijke hoogleraren dat zich inspant om kwesties rond genderongelijkheid binnen de academie aan de kaak te stellen, werden de portretten van mannelijke geleerden die vaak al sinds de vroegmoderne tijd in de ruimte hingen, tijdelijk verborgen achter een fotogordijn met daarop de gezichten van hun hedendaagse vrouwelijke evenknieën. (afb. 1 \& 2) Zo veranderde de in 1734 opgerichte academische eregalerij radicaal van gedaante en kreeg de (Leidse) wetenschap voor het eerst in bijna drie eeuwen - althans voor even - een primair vrouwelijk gezicht. Strategisch geplaatst in het ceremoniële hart van de academische gemeenschap moesten deze vrouwenportretten de aandacht vragen voor een meer divers beeld van het wetenschappelijk bedrijf waarin ruimte is voor zowel mannen als vrouwen, aldus de initiatiefnemers.

De transformatie van de Leidse Senaatszaal past binnen een bredere trend die zich de afgelopen jaren in de academische wereld aftekent. Alleen al in Nederland 


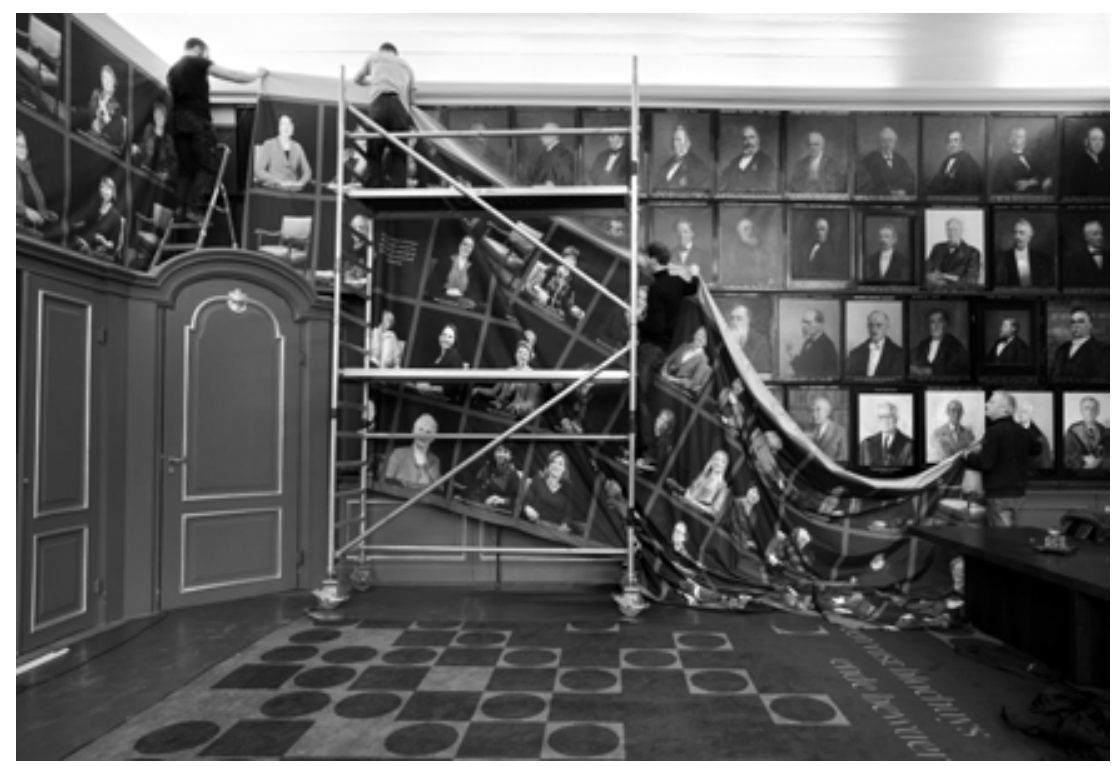

1. Op 8 maart 2016, internationale vrouwendag, werden de portretten in de Senaatskamer van de Universiteit Leiden, voor de duur van een maand, vervangen door een fotodoek met daarop de gezichten van vrouwelijke wetenschappers (Foto: Marc de Haan).

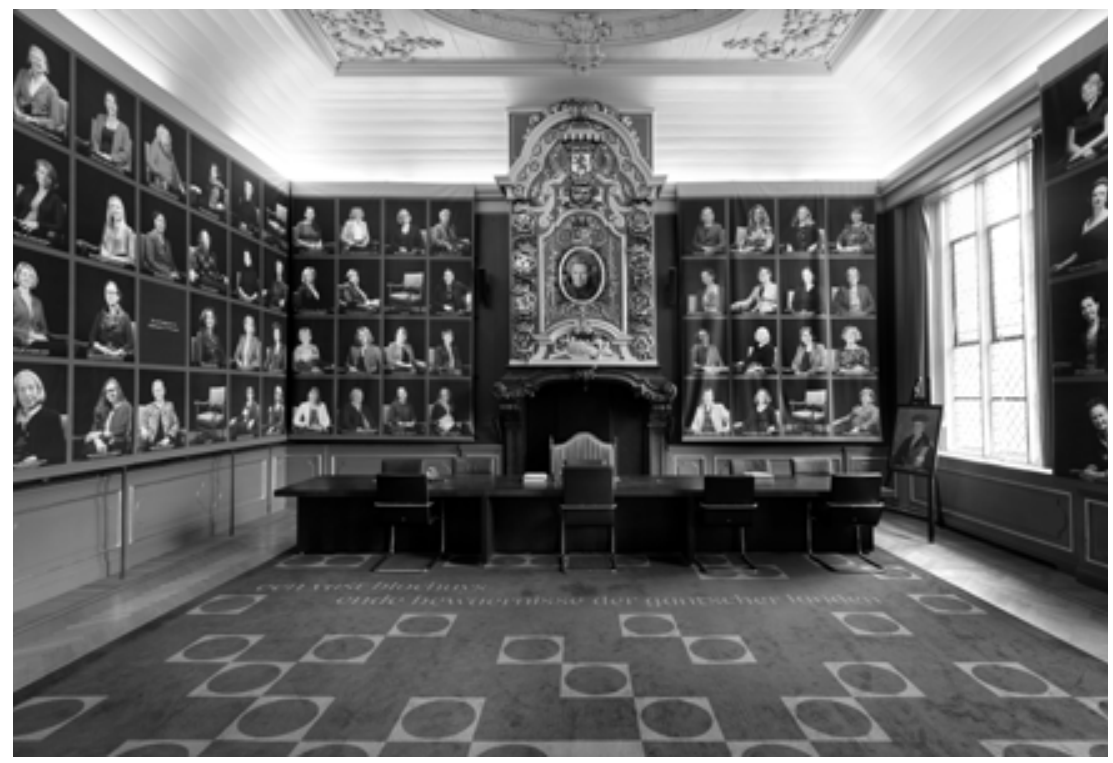

2. Het (tijdelijke) uiterlijk van de Senaatszaal van de universiteit Leiden na de metamorfose in maart 2016. Op de plaats boven de schouw waar traditiegetrouw het portret van Willem van Oranje hangt, prijkt nu de beeltenis van prinses Beatrix, die in 2005 een eredoctoraat van de universiteit ontving. Een print van het portret van de enige vrouw dat reeds in de Senaatskamer hing, Sophia Antoniades (1895-1972), in 1929 benoemd tot eerste Leidse vrouwelijke hoogleraar, werd tijdelijk op een ereplaats, rechts voor het raam, gezet. (Foto: Marc de Haan). 
ondergingen diverse - van origine veelal vroegmoderne - academiegalerijen een soortgelijke 'geslachtsverandering'. Ter gelegenheid van het honderdjarig jubileum van de aanstelling van Johanna Westerdijk (1883-1961) als eerste vrouwelijke hoogleraar in Nederland werden in 2017 de portretten van 122 vrouwelijke hoogleraren opgehangen in het Academiegebouw van de Universiteit Utrecht. Van nog recentere datum is de vernieuwingsgolf die door de Senaatskamer van de Rijksuniversiteit Groningen trok. ${ }^{3}$ Ook hier werd het van oudsher visuele mannenbastion omgevormd tot een meer eigentijdse en representatieve voorstelling van de academische gemeenschap. Vergelijkbare transformaties aan buitenlandse - overwegend westerse - universiteiten zijn eveneens talrijk. ${ }^{4}$

Al deze initiatieven beantwoorden aan het groeiend besef dat gendergelijkheid in de wetenschap niet louter valt te realiseren met een toenemend aantal vrouwen in de kennissector. Ook ingesleten beeldvormingspatronen die (mis)concepties van genderongelijkheid in stand houden, dienen te worden aangekaart. Hoewel deze recente initiatieven zich richten op de metamorfose van academiegalerijen die hun oorsprong veelal in de vroegmoderne tijd vonden, wordt deze beeldvormingsproblematiek toch vooral beduid als een modern fenomeen. Dat juist het geleerdenportret een aantrekkelijk medium blijkt om de kwestie van genderdiversiteit in de wetenschappelijke wereld aan de kaak te stellen, kent echter diepe historische wortels in de Europese geschiedenis. Zeker vanaf de vroegmoderne tijd ging het geleerdenportret een structurele rol spelen in de publieke representatie van intellectuele autoriteit. Dit stelde het groeiend aantal vrouwelijke geleerden dat een respectabele positie probeerde te veroveren in de geleerdenwereld voor zowel hindernissen als mogelijkheden ten aanzien van hun publieke beeldvorming. Deze bijdrage plaatst het appel dat deze initiatieven doen op portretten van vrouwelijke geleerden om het stereotiepe beeld van de wetenschapper te nuanceren, in historisch perspectief. Kennis over de ontwikkelingen en complexiteiten van de representatie van vrouwen als geleerden door de eeuwen heen, biedt inzicht in de hardnekkigheid van deze nog altijd urgentie kwestie en laat zien

3 R. Hoogschagen, 'RUG verjongt portrettengalerij: Meer vrouwen, minder dood', in: Ukrant, 24 juni 2019.

4 Eerder al ging Hertford College, dat in 1974 als een van de eerste colleges van Oxford vrouwelijk wetenschappelijk personeel aanstelde, haar Leidse zuster voor door portretten van mannelijke geleerden in de Great Hall te vervangen door een reeks gezichten van vrouwelijke wetenschappers. Ook in bijvoorbeeld Yale, Cambridge en Sussex werden vergelijkbare transformaties gerealiseerd. 
op welke wijze - in het verleden - geprobeerd is om bestaande stereotypering (met wisselend succes) te doorbreken.

$\mathrm{Na}$ een beknopte uiteenzetting over de hedendaagse studie naar de stereotiepe beeldvorming van wetenschappers, ga ik dieper in op de beeldbepalende rol die portretten al eeuwenlang, en in het bijzonder vanaf de vroegmoderne tijd, vervulden bij de (publieke) imagovorming van geleerden. Vervolgens sta ik stil bij de manier(en) waarop vrouwelijke geleerden inspeelden op de groeiende vraag naar geleerdenportretten. Op welke manier(en) werden zij verbeeld? Hoe valideerden en/of betwistten deze representaties het traditionele beeld van de geleerde? En hoe werden deze portretten door zowel vrouwelijke geleerden als hun (veelal mannelijke) tijdgenoten aangewend om te reflecteren op de mogelijkheden en onmogelijkheden voor vrouwen om wetenschappelijke autoriteit te belichamen? Ten slotte keer ik terug bij de parallel tussen verleden en heden: wat leren inzichten in de complexiteit van de beeldvorming van vrouwelijke geleerden in het verleden ons over de nog altijd woedende strijd tegen het stereotiepe beeld van de wetenschapper als man? En is portretkunst eigenlijk een effectief medium om deze beeldvormingsproblematiek aan te kaarten?

\section{Het beeld van de wetenschapper als modern fenomeen}

In de focus op de rol van beeldvormingsmechanismen bij het vormen en in stand houden van stereotypische voorstellingen van de wetenschapper beroepen deze recente initiatieven zich, al dan niet expliciet, op een doorlopende traditie van sociaalpsychologisch onderzoek dat vanaf de tweede helft van de twintigste eeuw is verricht. Onder de noemer 'Draw-a-Scientist Test' zijn vanaf de jaren 1960 een reeks experimenten uitgevoerd waarbij kinderen gevraagd werd een wetenschapper te tekenen, met als doel in kaart te brengen hoe sterk dit beeld gegenderd was, en te bepalen wat dit vervolgens zegt over stereotypering. ${ }^{5}$ Deze onderzoeken wezen steeds uit dat het merendeel van kinderen een wetenschapper voorstelt als een witte man, niet zelden gehuld in een laboratoriumjas, met bril en (in de regel, grijze) gezichtsbeharing. Slechts een enkeling tekende een vrouw. Hoewel resultaten van de meer recente onderzoeken van dit type de aarzelende opkomst van een meer divers beeld - waar-

5 Aan de basis van het Draw-A-Scientist-onderzoek staat de studie die David W. Chambers in de periode 1966-1977 verrichtte naar de tekeningen van bijna 50oo leerlingen uit het lagere onderwijs. D.W. Chambers, 'Stereotypic Images of the Scientist: The Draw-A-Scientist Test', in: Science Education, 67.2 (1983), pp.255-265. 
in overigens niet alleen ruimte ontstaat voor genderdiversiteit maar eveneens voor etnische variatie - markeren, blijkt de associatie tussen wetenschap en mannelijkheid nog altijd beeldbepalend. ${ }^{6}$ Door de schijnwerpers te richten op de vrouwelijke gezichten van geleerdheid beogen recente initiatieven dus een alternatief beeld te belichten en de bestaande dominante beeldvormingspatronen (verder) te doorbreken.

Opvallend is dat het ontstaan van het stereotype van de wetenschapper als man vaak expliciet is bestempeld als een modern fenomeen. Zowel in de historische onderbouwing van het 'Draw-a-Scientist'-onderzoek als in de verantwoording bij de recente metamorfoses van de academiegalerijen is de hardnekkige associatie tussen wetenschapper en man geduid als een directe uitwas van de institutionele transformatie die de wetenschap vanaf de negentiende eeuw onderging. In dit opzicht zijn de openingsregels van het eerste wetenschappelijke artikel dat verslag deed van het 'Draw-a-Scientist'-onderzoek illustratief:

During the eighteenth and nineteenth centuries visual and verbal images of the scientist were many and varied. Caricaturists, cartoonists, artists, and writers produced a diverse range of stereotypic figures: diabolical madmen, distinguished professors, harmless eccentrics, learned buffoons, and fashionable dilettantes. ${ }^{7}$

6 Voor een overzicht van de 'Draw-a-Scientist'-onderzoeken sinds de jaren zestig en een meta-analyse van de resultaten, zie: D.I. Miller e.a., 'The Development of Children's Gender-Science Stereotypes: A Meta-analysis of 5 Decades of U.S. Draw-A-Scientist Studies', in: Child Development, 89.6 (2018), pp.1943-1955. Op de synthetiserende conclusies van laatstgenoemde studie, en met name op de sociaalmaatschappelijke implicaties ervan, valt veel aan te merken dat buiten het bestek van deze bijdrage valt, maar treffend wordt verwoord in, F. Van de Velde, 'Oninteressant onderzoek: kinderen tekenen meer mannelijke wetenschappers dan vrouwelijke', https://www.neerlandistiek.nl/2018/o5/oninteressant-onderzoek-kinderen-tekenen-meer-mannelijke-wetenschappers-dan-vrouwelijke/, 13 mei 2018 (geraadpleegd 13 augustus 2020). 
Pas in de loop van de negentiende zou deze verscheidenheid aan voorstellingen zich vernauwen - of liever: standaardiseren - tot het stereotype van de geleerde als man. ${ }^{8}$

Deze observatie is zeker niet uit de lucht gegrepen, maar wordt bijvoorbeeld ook ondersteund door de recente stroom aan wetenschapshistorisch onderzoek naar de opkomst en functie van zogenaamde scholarly personae. Diverse studies hebben inzichtelijk gemaakt dat het voor vrouwelijke geleerden zeker vanaf de negentiende eeuw complex zo niet onmogelijk werd om te voldoen aan de deugden en karakteristieken die de ideale wetenschapper op dat moment moest bezitten. ${ }^{9}$ Bijzonder nadelig bleek bovendien de veranderende ruimte waarin het toonaangevende wetenschappelijke debat werd gevoerd. Konden vrouwen in de zeventiende en achttiende eeuw nog (zij het sporadisch) participeren aan het intellectuele debat dat in de publieke ruimte van bijvoorbeeld salons werd gevoerd, vanaf de negentiende eeuw ging de wetenschap zich primair afspelen achter de, voor vrouwen gesloten, deuren van de universiteit. ${ }^{10}$

Wie deze beeldvorming echter loskoppelt van de institutionele context en in meer algemene zin naar de pogingen van vrouwen om geleerdheid te belichamen kijkt, ziet dat deze beeldvormingsproblematiek een veel langere geschiedenis kent. Met name de vroegmoderne tijd, waarin een snelgroeiend aantal vrouwen ging participeren in

8 Vergelijk ook de opmerkingen van Judi Mesman, hoogleraar Diversiteit in Opvoeding en Ontwikkeling en een van de vier initiatiefnemers van Athena's Angels, en Yra van Dijk, hoogleraar Moderne Nederlandse Letterkunde, in de het promotiefilmpje 'Ruimte voor vrouwen in de Senaatskamer', https://www.universiteitleiden.nl/ nieuws/2016/o3/ruimte-voor-vrouwen-in-de-senaatskamer, 8 maart 2016 (geraadpleegd 13 augustus 2020).

9 Studies over het concept wetenschappelijke personae (en, in het verlengde hiervan, scholarly en/of scientific personae) zijn talrijk. Ik beperk me tot enkele toonaangevende titels: L. Daston \& H.O. Sibum, 'Introduction: Scientific Personae and Their Histories', in: Science in Context, 16.1-2 (2003), pp.1-8; H. Paul, 'Sources of the Self: Scholarly Personae as Repertoires of Scholarly Selfhood', in: Bijdragen en Mededelingen betreffende de Geschiedenis der Nederlanden, 131.4 (2016), pp.135-154; K. Niskanen, M. Bosch $\&$ K. Wils, 'Scientific Personas in theory and practices - Ways of Creating Scientific, Scholarly, and Artistic Identities', in: Persona Studies, 4.1 (2018), pp.1-5. Over de worsteling van vrouwelijke geleerden om te voldoen aan het ideaalbeeld van de (moderne) wetenschapper, zie: M. Bosch, 'Persona and the Performance of Identity: Parallel Developments in the Biographical Historiography of Science and Gender, and the Related Uses of Self Narrative', in: L'homme. Europäische Zeitschrift für Feministische Geschichtswissenschaft, 24.2 (2013), pp.11-22; M. Bosch, 'Scholarly Personae and Twentieth-Century Historians: Explorations of a Concept', in: BMGN, 131.4 (2016), pp.33-54, aldaar pp.50-53.

10 Over de institutionalisering van de wetenschappen en de veranderende positie van vrouwen hierin, zie bijvoorbeeld, J. Tollebeek, Mannen van karakter: De wording van de moderne geesteswetenschappen, Amsterdam 2011, pp.51-55. 
het intellectuele debat en portretkunst een essentieel onderdeel werd van de publieke reputatievorming van de geleerde, was een formatieve periode in de verbeelding van vrouwen als wetenschappers. Reeds in de vroegmoderne tijd vonden beeldvormingsmechanismen die nog altijd in werking zijn hun opgang.

\section{Vroegmoderne geleerdenportretten als (toon)beeld van intellectuele autoriteit}

Vanaf de zestiende eeuw gingen de gezichten van geleerden een steeds belangrijkere rol spelen in de constructie van intellectuele autoriteit. Hoewel portretten van geleerden en schrijvers al vanaf de klassieke oudheid circuleerden, verwierf het genre definitief populariteit in de loop van de vroegmoderne tijd. Onder zestiende-eeuwse humanisten ontstond het gebruik om portretten van zichzelf bij te sluiten in hun brieven bij wijze van face-to-face introductie met een collega die zij hoogstwaarschijnlijk nooit persoonlijk zouden ontmoeten. ${ }^{11}$ In toenemende mate verbeeldden deze portretten de geleerde, volledig bevangen door het proces van kennisvergaring, in zijn natuurlijke habitat: het studeervertrek. Geleerdenportretten kregen ook zelf een prominente plaats in bibliotheken en studeervertrekken. ${ }^{12}$ In zijn Bibliothecis syntagma (1620), een verhandeling over de geschiedenis en functie van de bibliotheek, riep Justus Lipsius (1547-1606) zijn tijdgenoten bijvoorbeeld op om zich in hun bibliotheken, naar klassiek gebruik, te omringen door de beeltenissen en bustes van geleerde voorgangers: 'We voelen ons heel natuurlijk door de portretten der uitstekende mannen aangetrokken, en worden uitgelokt tot nadere kennismaking met hun beeltenis en met hun persoon of hun woning, waarin de hemelsche geest zich heeft opgehouden', zo lichtte hij toe. ${ }^{13}$

Het toenemend belang dat aan geleerdenportretten werd gehecht bij de verbeelding van intellectuele autoriteit wordt eveneens duidelijk uit verschillende publicatie-initiatieven die in de eerste decennia van de zeventiende eeuw in de directe

11 F. Waquet, 'Les savants face à leurs portraits', in: Nouvelles de l'estampe, 117 (1991), pp.22-28.

12 G. le Thiec, 'Dialoguer avec des hommes illustres. Le rôle des portraits dans les décors de bibliothèques (fin XVe-début XVIIe siècle)', in: Revue française d'histoire du livre, 130 (2009), pp.7-52.

13 J. Lipsius, De bibliothecis syntagma, Antwerpen 1602, vert. C. Sobry, 'Justus Lipsius: De bibliothecis syntagma uit het Latijn in het Nederlandsch vertaald', in: De Gulden Passer (1941), pp.57-98, aldaar pp.91-94. 


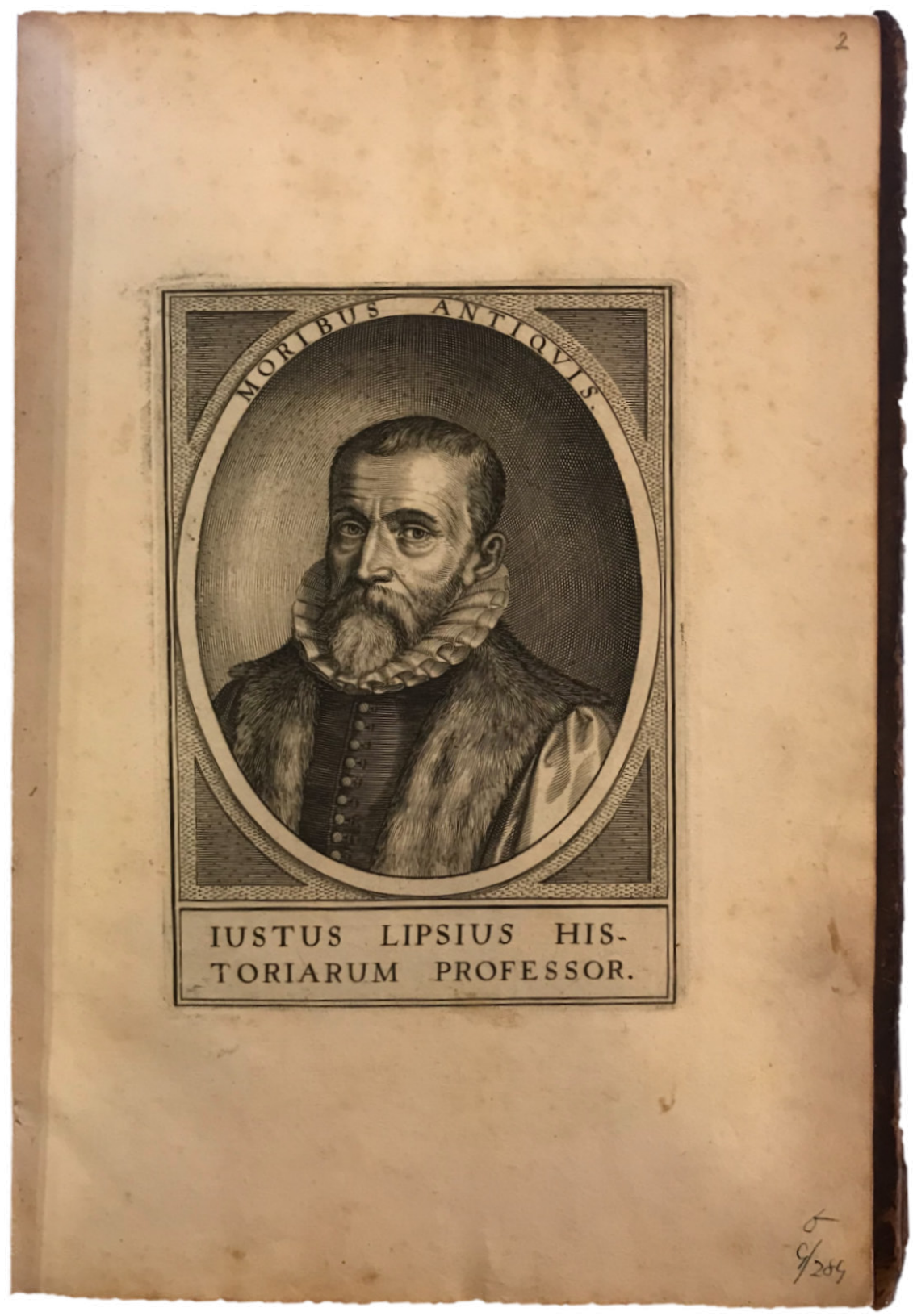

3. Willem van Swanenburg, Portret van Justus Lipsius, humanist en hoogleraar rechtsgeleerdheid en geschiedenis te Leiden en Leuven, in: Icones ad vivum elineatæ et expressæ, virovm clariovum qui præcipue scriptis Academiam Lvgdvno Batavam illustrarunt, Leiden 1609. Universiteitsbibliotheek Leiden, inv.nr. 190 B 13; 


\section{GVLIELMVS FEVGVERÆVS.}

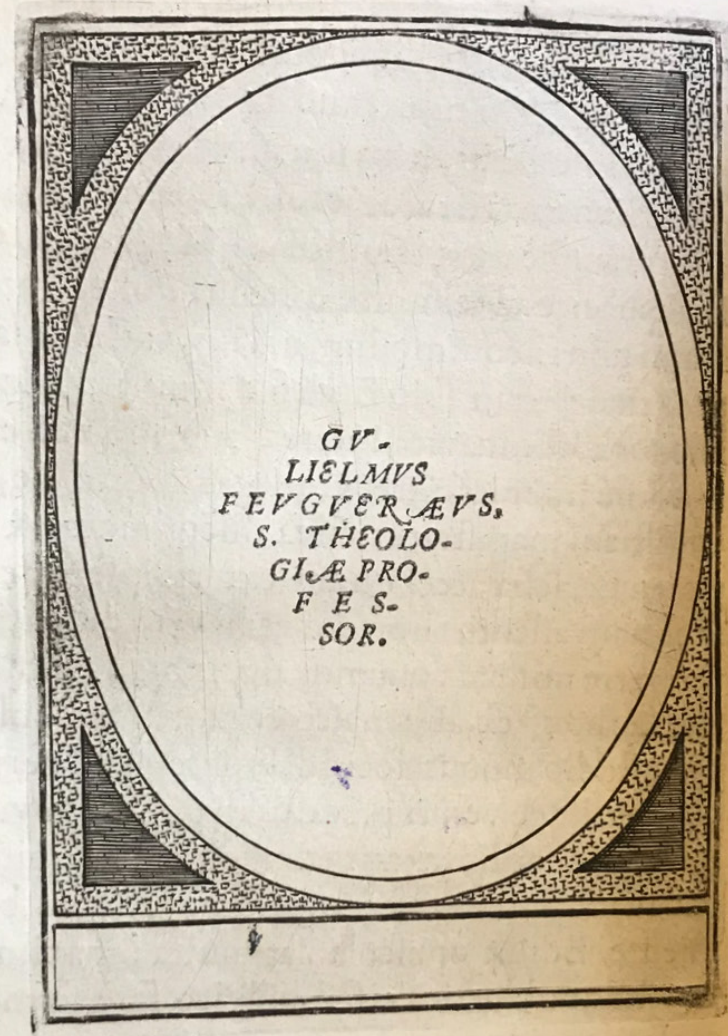

GVI

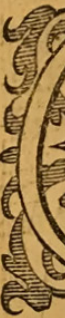

eam

nebal

licibı

ret; $\mathrm{V}$

I) $\mathrm{LXX}$

ipfo al

folus

ordina

lega ad

difput

propor

miam

dem

GVLIEL.

quã ind adeò ut

cere

do mag

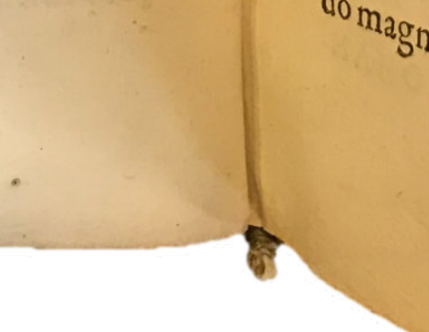

4. Als het portret van een geleerde, in dit geval de hoogleraar godsgeleerdheid Gulielmus Feugueraeus (ca. 1535-1613), niet voor handen was, werd een lege lijst opgenomen die later kon worden ingevuld. Deze pagina is afkomstig uit Illustrium Hollandiae \& VVestfrisae ordinvm alma academia Leidensis, Leiden 1614. Universiteitsbibliotheek Leiden, inv. nr. 116 B 16. 
omgeving van de universiteit van Leiden werden ontplooid. Inspelend op de groeiende reputatie van de jonge universiteit als kennisbrandpunt van Europa, brachten Leidse drukkers een serie boeken, de zogenaamde Icones, op de markt waarin de portretten en in latere uitgaven later ook de levensbeschrijvingen - van de meest vooraanstaande leden van de Leidse academische gemeenschap waren samengebracht. ${ }^{14}$ (afb.3) In de beknopte Latijnse inleiding bij de eerste uitgave van de Icones uit 1609, werd de kracht van het gezicht bij de voorstelling van intellectuele autoriteit onderstreept:

Vooral in het gelaat is door de natuur beschreven wat ieder van ons is. In het gezicht heeft de grote moeder, de natuur, het beeld van onszelf aangebracht, en dat in lijnen en halen uitgedrukt als in schrift. Zo weerspiegelt zich ieders geleerdheid, deugdzaamheid, en oprechtheid, zoals die in ons schuilgaan, in de ogen, mond en het voorkomen. ${ }^{15}$

De gezichten boden, met andere woorden, een directe inkijk op de intellectuele capaciteiten die Leiden in huis had. Deze gedrukte portrettengalerijen functioneerden, zoals boekhistoricus Anthony Grafton stelde, als 'the seventeenth-century equivalent of a website'. ${ }^{16}$ Zoals haar moderne 'opvolger', verspreidde de reeks een attractief beeld van de universiteit onder een breed publiek. Als een portret van een eminente geleerde niet voorhanden was, werd zelfs een leeg kader opgenomen waarin op een later moment alsnog een gezicht geplaatst kon worden. (afb. 4) De uitgaven bleken een succesformule die ook door andere universiteiten werd aangewend. ${ }^{17}$ Daarnaast

14 Icones (1609), Illustris Academia (1613), Icones, elogia ac vitae (1617) en Athenae Batavae (1625) verschenen bij de Leidse uitgever Andries Clouck met gegraveerde portretten van de Leidse kunstenaar Willem van Swanenburg. Het succes van de formule blijkt eveneens uit het verschijnen van een vijfde titel, Alma Academia (1614), bij de concurrerende uitgevers Jacob Marcus en Joost van Colster. Over de geschiedenis van de Icones, zie: M. Tolsma, Van Icones tot Effigies. De in 1609 in boekvorm uitgegeven portrettencollectie van Leidse geleerden en haar navolgers, Leiden 2016.

15 'Sed praecipue in vulta id quod quisque sumus a nutura est descriptum, in quo nostri imaginem magna illa mater proposuit, lineisque ac ductibus quibusdam, quasi litteris, expressit. Ita erudition cuiusque, probitas, ac candor, ut in animo latat, sic in oculis, ore, ac fronte apparet.' Icones, Leiden 1609.

16 A. Grafton, Athenae Batavae. The Research Imperative at Leiden, 1575-1650, Leiden 2003, p.12.

17 Cf. de gedrukte collectie Groningse hooglerarenportretten en - levensbeschrijvingen die in 1654 werd uitgegeven. Effigies \& Vitæ professorvm academix Groningx \& Omlandix, Groningen 1654 . 
vormden zij, in veel gevallen, de directe opmaat tot de inrichting van academische portrettengalerijen in aula's, senaatszalen of universiteitsbibliotheken. ${ }^{18}$ Vanzelfsprekend ontbraken de gezichten van vrouwelijke geleerden - voor wie de universiteit ook in de vroegmoderne tijd reeds onbegaanbaar terrein was - in deze academische overzichten. Er zijn overigens wel enkele uitzonderingen op de regel: zo werd Anna Maria van Schurman (1607-1678) in 1636 als eerste vrouwelijke student toegelaten tot een universiteit. Ze verwierf het privilege om - zij het vanachter een gordijn zodat haar mannelijke medestudenten haar niet konden zien - colleges te volgen aan de universiteit van Utrecht. In 1732 behaalde Laura Bassi (1711-1778) een universitaire graad en wist zij als eerste vrouw een onderwijsmandaat aan een Europese universiteit te bemachtigen. ${ }^{19}$

De groeiende publieke fascinatie voor de uiterlijke karakteristieken van geleerden vond bovendien neerslag in de boekproductie in meer algemene zin en beïnvloedde zodoende ook de beeldvorming van de groeiende groep geleerde vrouwen die steeds vaker de weg naar de drukpersen wisten te vinden. Vrijwel direct na de uitvinding van de boekdrukkunst begonnen drukkers en boekverkopers met het bijsluiten van een portret van de auteur in een boek, vanzelfsprekend met het doel de verkoop te bevorderen. In de loop van de zeventiende eeuw - gestimuleerd door technologische innovaties van de drukpers - steeg de productie van auteursportretten, die zowel werden ingevoegd in boeken als los verzameld, explosief. ${ }^{20}$ Binnen de context van het boek functioneerden dergelijke gravures, zoals boekhistoricus Roger Chartier stelde,

18 Over de academische portrettengalerij van de Universiteit Leiden, zie: M.F. van Kersen-Halbertsma, R.E.O. Ekkart \& H. van de Waal (red.), Icones Leidenses: de portretverzameling van de Rijksuniversiteit te Leiden, Leiden 1973. Over Groningen: R.E.O. Ekkart \& J. Schuller tot Peursum-Meijer, Groninger academieportretten: catalogus van de portretten in het Academiegebouw en de Bibliotheek van de Rijksuniversiteit te Groningen, Groningen 1978. Over Amsterdam: I.Q. van Regteren Altena \& P.J.J. van Thiel, De portretgalerij van de Universiteit van Amsterdam en haar stichter Gerard van Papenbroek, 1673-1743, Amsterdam 1964.

19 Over Van Schurman en haar toetreden tot de Universiteit Utrecht, zie: P. van Beek, The First Female University Student: Anna Maria van Schurman (1636), Utrecht 2010. Over Bassi: P. Findlen, 'Science as a Career in Enlightenment Italy. The Strategies of Laura Bassi', in: Isis, 84 (1993), pp.441-469.

20 A. Griffiths, The Print in Stuart Britain, 1603-1689, London 1998, p.139; P. Burke, 'Reflections on the Frontispiece Portrait in the Renaissance', in: A. Köstler \& E. Seidl (red.), Bildnis und Image: Das Portrait Zwischen Intention und Rezeption, Keulen 1998, pp.150-162, aldaar pp.151-154 en A. Griffiths, The Print Before Photography: An Introduction to European Printmaking 1550-1820, London 2016, p.399. 
als een 'expression of an individuality that gives authenticity to the work'. ${ }^{21}$ Geplaatst voorafgaand aan een tekst dwongen zij de lezer om de autoriteit van de auteur te erkennen. ${ }^{22}$ Als zodanig gingen portretten een beeldbepalende rol spelen bij de imagovorming van geleerden en, in meer algemene zin, schrijvers. ${ }^{23}$ In de regel werden deze portretten zorgvuldig geconstrueerd en bevatten zij zowel iconografische als tekstuele elementen die waren bedoeld om de geleerde status van de geportretteerde optimaal te onderstrepen.

\section{Het probleem van de publieke geleerde vrouw}

De groeiende vraag naar gedrukte portretten van levende auteurs stelde vroegmoderne vrouwelijke geleerden voor een uitdaging. Hoewel vrouwen steeds vaker hun werken onder hun eigen naam publiceerden en zodoende openlijk een positie in het intellectuele debat claimden, bleek het drukken van hun afbeelding een heikel punt in hun publieke (zelf)representatie. In een tijd waarin in het openbaar spreken en publiceren door vrouwen nog vaak in strijd werd geacht met de sociale normen en eisen van welvoeglijkheid werd het publiceren van een portret, met als doel de verspreiding onder een breed en veelal anoniem publiek, al snel afgedaan als aanstoot-

21 R. Chartier, The Order of Books. Readers, Authors, and Libraries in Europe Between the Fourteenth and Eighteenth Centuries, Cambridge 1994, p.52.

22 Over het functioneren van gedrukte portretten binnen de (overwegend tekstuele) context van het boek: K. Enenkel, 'The Author's Portrait as Reader's Guidance: The Case of Francis Petrarch', in: C. Brusati, K. Enenkel \& W. Melion (red.), The Authority of the Word. Reflecting on Image and Text in Northern Europe, 1400-1700, Leiden \& Boston 2011, pp.149-180; S. Howe, 'The Authority of Presence. The Development of the English Author Portrait, 1500-1640', in: The Papers of the Bibliographical Society of America, 102.4 (2008), pp.465-499.

23 Voor een schets van de rol van gedrukte portretten in de branding van auteurschap en intellectuele en literaire autoriteit, zie: L. van Deinsen \& N. Geerdink, 'Cultural Branding in the Early Modern Period: The Literary Author', in: H. van den Braber e.a. (red.), Branding Books Across the Ages. The Case of Dutch Literature (1600-2018), Amsterdam 2020 (ter perse). 
gevend of zelfs zedeloos. ${ }^{24}$ Lange tijd werden dan ook hoofdzakelijk de portretten van reeds overleden geleerde - en niet zelden religieuze - vrouwen op de markt gebracht. Deze gedrukte portretten hadden primair een herinneringsfunctie. Als een levende vrouwelijke geleerde besloot zich te laten portretteren ten behoeve van haar publieke beeldvorming bleek het vaak een kwestie van compositorische sinecure.

Hoezeer vrouwelijke geleerden zich ten aanzien van hun visuele (zelf)representatie op een precair spanningsveld bevonden ten aanzien van het heersende sociale verwachtingspatroon, wordt levendig geïllustreerd door de geschiedenis die zich voltrok rond het eerste gedrukte zelfportret van Anna Maria van Schurman (1607-1678). Niet alleen was Van Schurman een van de meest geleerde vrouwen van haar tijd, ook etaleerde zij een uitgesproken interesse voor het vormgeven van haar publieke imago, zowel in woord als in beeld. ${ }^{25}$ Met name tijdens de eerste decennia van haar intellectuele loopbaan wendde ze haar kunstzinnige talenten aan voor het vervaardigen van diverse zelfportretten. ${ }^{26}$ In 1633, amper 25 jaar oud, etste en graveerde zij haar eerste zelfportret. ${ }^{27}$ (afb. 5) Het Latijnse onderschrift dat Van Schurman onder haar beeltenis opnam, maakt inzichtelijk hoe zij probeerde het prevalerende vrouwelijke

24 C. Simonin, 'Les portraits de femmes auteurs ou l'impossible representation', in: Richard Crescenzo (red.), Espaces de l'image, Europe XVI-XVIIe siècles, Nancy, 2002, pp.35-57; M. Ezell, 'Seventeenth-Century Female Author Portraits, Or, The Company She Keeps', in: Zeitschrift für Anglistik und Amerikanistik 60.2 (2012), pp.31-38; L. van Deinsen, 'Visualising Female Authorship. Author Portraits and the Representation of Female Literary Authority in the Eighteenth-Century Dutch Republic', in: Quærendo, 49.4 (2019), pp.283-314, aldaar pp.285-287. Over het commerciële doel van de publicatie van geleerden- en auteursportretten, zie: Griffiths, The Print Before Photography, pp.396-397; The Multigraph Collective, Interacting with Print. Elements of Reading in the Era of Print Saturation, Chicago 2008, pp.143-144.

25 Over Van Schurman en haar intellectuele prestaties, zie (naast de voornoemde publicatie van Van Beek), ook: M. de Baar e.a. (red.), Anna Maria van Schurman (1607-1678): een uitzonderlijk geleerde vrouw, Zutphen, 1992 en A.R. Larsen, Anna Maria van Schurman, 'Star of Utrecht': the educational vision and reception of a savante, London \& New York 2016.

26 Nagenoeg alle zelfportretten van Van Schurman zijn beschreven in: K. Van der Stighelen, Anna Maria van Schurman (1607-1678), of "Hoe hooge dat een maegt kan in de konsten stijgen", Leuven 1987.

27 Voor een beschrijving en duiding van het portret, zie ook: Van der Stighelen, Anna Maria van Schurman, pp.119-121. 
bescheidenheidsideaal te verenigen met haar ambitie zich te voegen bij de intellectuele elite van haar tijd:

Geen troost of schoonheid raadde mij aan

Mijn gelaatstrekken te graveren in 't onvergankelijke koper;

Maar het was opdat, indien mijn ongeoefende stift nog geen goed werk kon leveren, Ik mij voor de eerste maal niet wagen zou aan een gewichtigere taak. ${ }^{28}$

Enerzijds benadrukken haar verzen dat Van Schurman met het graveren van haar eigen gelaat geen ijdele of pronkzuchtige ambitie koesterde. Integendeel, zo stelde zij, net door haar eigen gelaat als onderwerp te kiezen, kon haar ongetrainde hand louter haar eigen beeltenis verpesten. Anderzijds etaleerde zij, door deze verzen in zorgvuldig Latijn te componeren, haar uitzonderlijke bekwaamheid om (als vrouw) de taal van de geleerden te beheersen.

Of de ambitieuze Van Schurman volgens haar tijdgenoten geheel slaagde in haar opzet om de rollen van vrouw en (aspirant) geleerde te verenigen, valt nog te bezien. Conform de heersende conventie onder de zeventiende-eeuwse intelligentsia, voegde zij haar beeltenis toe aan haar correspondenties. Zo belandde haar gedrukte gezicht in de winter van 1634 in de handen van een van de meest vooraanstaande geleerden van haar tijd: dichter en diplomaat Constantijn Huygens (1596-1687). Als dank voor haar beeltenis zond Huygens haar een dozijn versjes waarin hij het aanstormend intellectuele talent niet alleen prees om haar geestelijk daadkracht en scherpzinnig oogopslag, maar zich eveneens enkele steelse toespelingen veroorloofde op de afwezigheid van haar handen: 'Uw portret stemt me dankbaar, maar, Tiende Muze, waarom/ het meest illustere deel verbergen, bewonderenswaardige vrouwe?'29 In rap tempo volgden de mogelijke verklaringen die de dichter te binnen schoten elkaar

28 'Non animi fastus, nec formae gratia suasit/ Vultus aeterno sculpere in aere meos:/ Sed, si forte rudis stilus hic Meliora negaret/ Tentarem prima ne potiora vice/ A.M. a Schurmā sculp. et delin/ Anno 1633'.

29 'De facie gratum est: se denim bis quinta Dearum,/ Cur magis illustri parte stupenda lates?'. Gedicht van Huygens aan Van Schurman daterend 2 december 1634, opgenomen in: J.A. Worp (red.). Constantijn Huygens, Gedichten. Deel 2: 1623-1636, Groningen 1893, p.299. Een gedetailleerde beschrijving van de uitwisseling tussen Huygens en van Schurman, is te vinden in: K. Van der Stighelen \& J. De Landsheer, 'Een suer-soete Maeghd voor Constantijn Huygens: Anna Maria van Schurman (1607-1678)', in: E. Kloek, F. Blom \& A. Leerintveld (red.), Vrouwen rondom Huygens, Hilversum 2010, pp.149-2O2; zie ook: K. Van der Stighelen, 'Constantijn Huygens en Anna Maria van Schurman: veel werk, weinig weerwerk', in: De Zeventiende Eeuw, 3.2 (1987), pp.138-148. 


\section{Spiegels van Sophia}

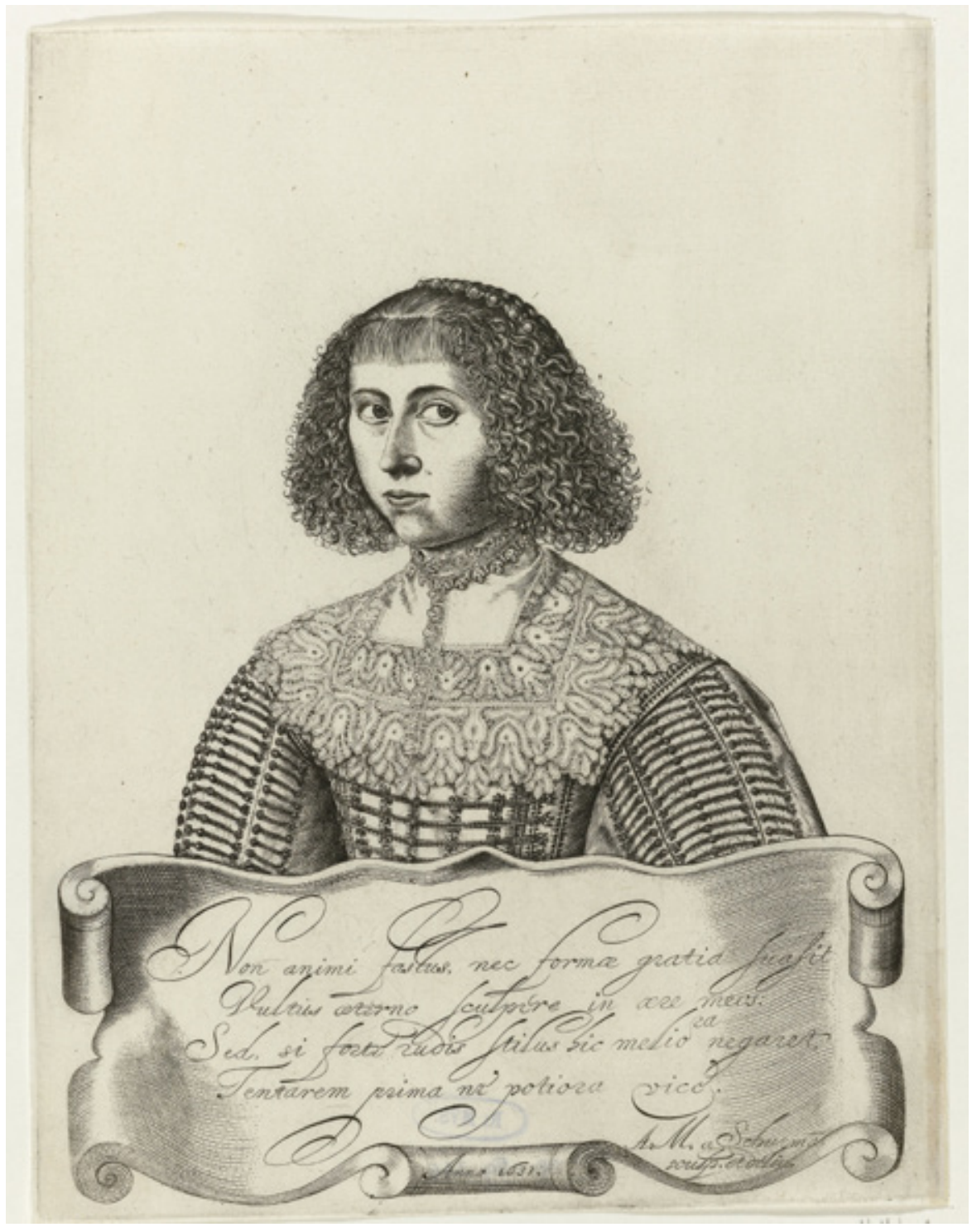

5. Anna Maria van Schurman, Zelfportret, 1633, ets en gravure. Rijksmuseum Amsterdam, objectnr. RP-P-OB-59.344. 
op: waren haar getalenteerde vingers mogelijk gekwetst door de scherpe graveerpen of waren er anderszins redenen waarom de ongehuwde Van Schurman haar 'ringloze' vingers niet blootgaf? Afgezien van deze onschuldige flirtages zal Van Schurman vooral gevleid zijn geweest door de waardering die zij ontving van het intellectuele zwaargewicht. Minder gelukkig was ze vermoedelijk geweest, had ze geweten dat haar portret Huygens en zijn goede vriend, de Amsterdamse hoogleraar Caspar Barlaeus (1584-1648), enkele weken later zou inspireren tot een poëtisch duel. Het ontzag dat de (voor een vrouw) vrijwel ongeëvenaarde eruditie van de jonge geleerde Van Schurman bij de mannen teweeg had gebracht, verdween al snel naar de achtergrond. In een gedichtwisseling doorspekt met erotische dubbele bodems dongen de zelfbenoemde 'tweeling-vrijers' onderling naar de hand van het 'Meysjen handeloos'. Het zou een kansarme queeste zijn, zo verzuchtte Barlaeus: 'Anna wenst dat die handen zouden ontbreken/ Daar is een reden voor: het meisje wil niet dat een man haar aanraakt'. ${ }^{30}$ Zo werd het eerste portret dat de ambitieuze Van Schurman de wereld in bracht al snel onderwerp van een vertoog dat niet draaide om de zaak waar het haar om ging: haar positie als (aanstormend) intellectueel talent.

Het zou bovendien niet de laatste keer zijn dat een portret van Van Schurman omgeven werd door een sfeer van zinnelijkheid. Evenmin tevreden moet de ambitieuze Van Schurman zijn geweest met het verschijnen van haar portret in een gedrukte portrettengalerij ontsproten aan de commerciële geest van uitgeverstelg Crispijn van de Passe (II) (1594-1670). ${ }^{31}$ (afb. 6) Ondanks de ogenschijnlijk brave titel die Van de Passe de verzameling portretten van beroemde Europese vrouwen meegaf - namelijk: Les vrais poutraits de quelques unes des plus grandes dames de la chrstiente (Ware Afbeeldinghe van eenige der Aldergrootste ende Doorluchtigste Vrouwen van heel Christenrij$c k$, vertoont in gedaente als herderinnen) (1640) - was het voor tijdgenoten zonneklaar dat het ging om het vervolg op de meest spraakmakende besteller uit zijn fonds. De uitgave vormde een tweeluik met de populaire Le miroir des plus belles courtisannes de ce temps (Spieghel der Allerschoonsten Courtisannen dieser zeit), een embleembundel met portretten van de bekendste courtisanes uit Europa, waarvan de eerste druk in

30 'Manibus, manibus cupit Anna carere,/ Et causa est: non vult tangere virgo virum'. Gedicht 'In virginem ultrajectinam, sine manibus pictam ad Constantinum Hugenium', van Barlaeus aan Huygens, 25 december 1634, in: J.A. Worp (red.). Constantijn Huygens, Gedichten. Deel 2: 1623-1636, Groningen 1893, pp.304-305.

31 Over de relatie tussen het drukkersgezin Van de Passe en Van Schurman, zie: Van der Stighelen, “"Et Ses Artistes Mains...”. De kunstzinnigheid van Anna Maria van Schurman', in: De Baar e.a. (red.), Anna Maria van Schurman, pp.61-74. 


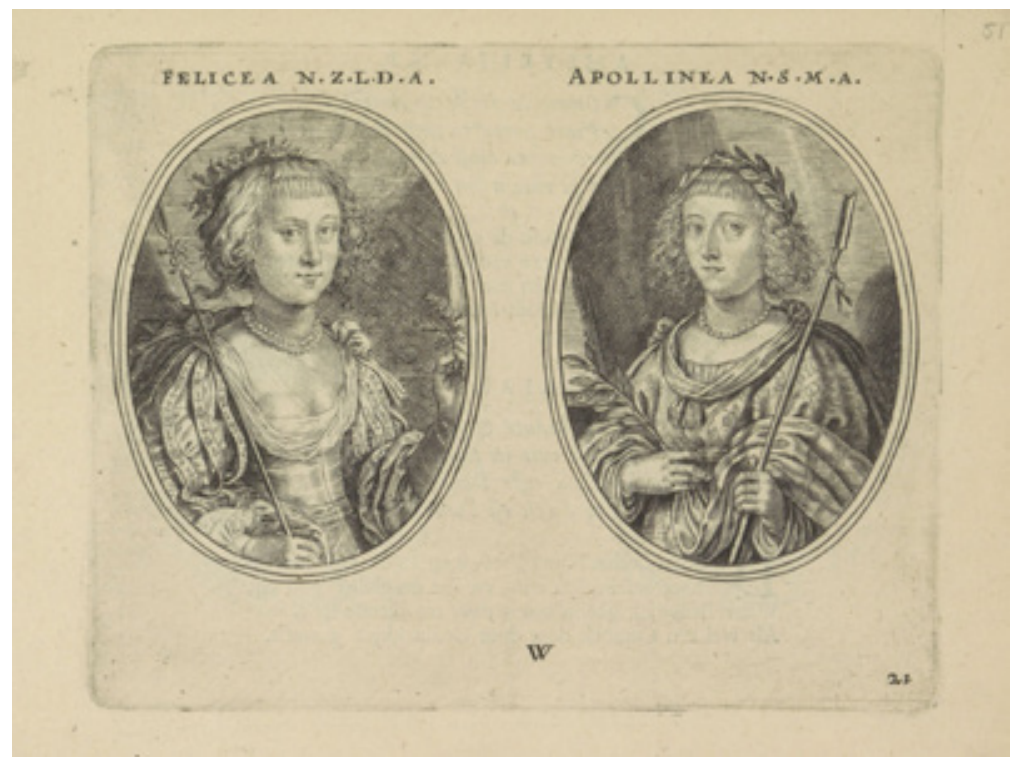

6. Crispijn van de Passe (II), Portret van een onbekende vrouw en Anna Maria van Schurman, 1640, gravure. Rijksmuseum Amsterdam, objectnr.: BI-1946-663-51.

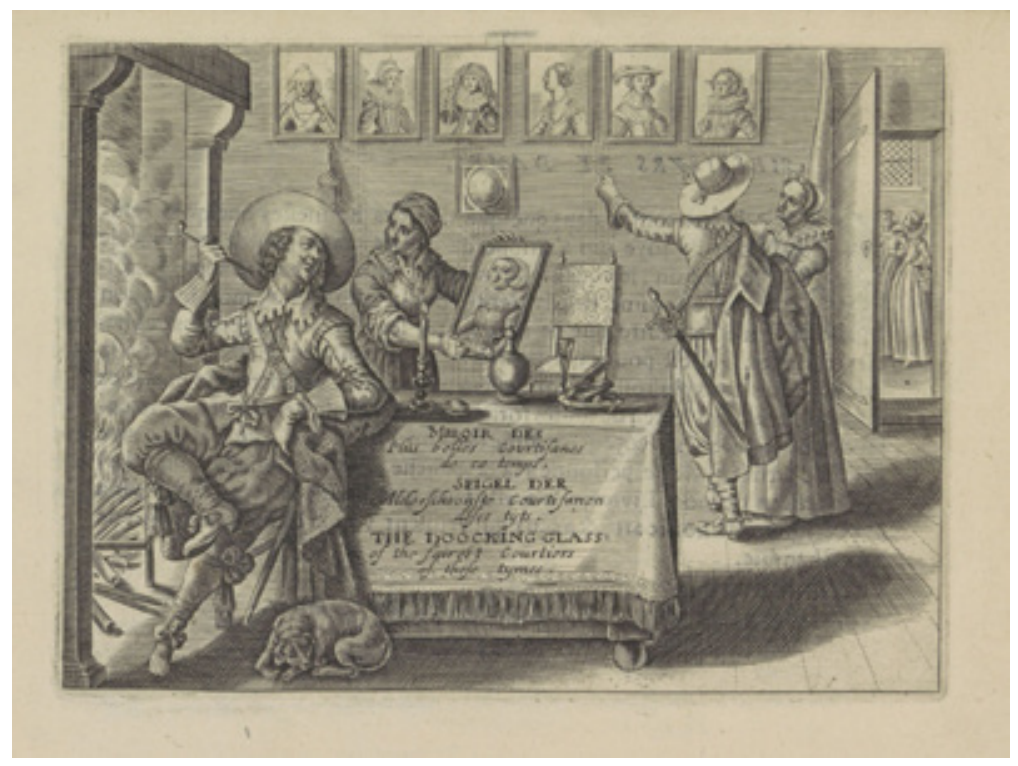

7. Crispijn van de Passe (II), Titelprent van Miroir des plus belle courtisanes de ce temps, 1635, gravure. Rijksmuseum Amsterdam, objectnr.: BI-1946-662-3. 
1630 was verschenen. ${ }^{32}$ De titelprent van laatstgenoemde publicatie illustreert de zedeloze kant die kon kleven aan het portret van een vrouw. (afb. 7) De gravure verbeeldt een bordeelscène: de ene klant maakt door te wijzen naar een portret kenbaar welk meisje hij begeert, terwijl een ander - gezeten voor het oplaaiend minnevuur - wacht tot de koppelaarster hem het gezicht van een meisje van zijn gading toont. In analogie krijgen de lezers in de bladzijden die volgden een 'portretcatalogus' voorgespiegeld van speelse vrouwen. Hoewel Van de Passes Doorluchtigste vrouwen geen meisjes van lichte zeden maar geleerde en adellijke vrouwen in de etalage plaatste, speelde ook bij deze uitgave de ambivalente status van het vrouwportret een sleutelrol. Om de zedigheid van de geportretteerde vrouwen te bewaren, zo lichtte de drukker in een dubbelzinnig voorbericht toe, 'heb ik die zelve op een bezondere gewoonte willen vertoonen, onder kleding van Herderinnen; en dat onder bedeckte namen: om niet lichtelijk in oordeel te vallen [...] en boven al dat de Jong-mans geen roem zullen dragen, dat ze der Jufferens afbeeldingen in hun zacken hebben'. ${ }^{33}$ Zo werd voor een tweede maal het gegraveerde portret van Van Schurman voorwerp van mannelijke begeerte.

Uiteindelijk vond het portret van Van Schurman ook de weg naar de compendia van geleerdenportretten die haar goedkeuring, naar alle waarschijnlijkheid, wel konden verdragen. Uit het opnemen van haar portret in het tweede deel van Isaac Bullarts (1599-1672) Académie des Sciences et des Arts (1683), waar zij schitterde tussen de vooraanstaandste mannelijke geleerden van haar tijd, blijkt dat er langzaam ruimte ontstond om ook vrouwen toe te laten tot het mannenbastion van geleerdheid. ${ }^{34}$ Maar ook hier werd haar opmerkelijke aanwezigheid niet verantwoord door haar objectieve intellectuele kwaliteiten. Van Schurman had haar opname, zo meldde de editeur, vooral te danken aan het feit dat zij als vrouw een zeldzame uitzondering op de regel was. Kennis en wetenschap waren nog altijd primair een mannenzaak.

32 In 1630 was de eerste editie van Van de Passes hoerenspiegel verschenen, naar alle waarschijnlijkheid in Parijs. Al snel volgden diverse heruitgaven, waarbij de Franse versjes werden aangevuld met Nederlandse en later ook Engelse teksten, elkaar op. Zie voor een beschrijving en duiding van het drukkersfonds van Van de Passe: I. Veldman, Crispijn de Passe and his progeny (1564-1670): a century of print production, Rotterdam 2001.

33 Ware afbeeldignhe van eenige der aldergrootste ende doorluchtigste vrouwen van heel Christenrijk, vertoont in gedaente als herderinnen, Amsterdam 1640, voorwoord.

34 I. Bullart, Academie des Sciences et des Arts, 2 dln, Brussel 1682-1683, dl. 2, p.228. Voor navolgers, vgl. bijvoorbeeld het portret van Van Schurman in Jan Frans Foppens' alfabetische overzicht van bijna drieduizend auteurs en hun werken. Bibliotheca Belgica, Brussel 1739. Het ingenaaide portret van Van Schurman bevindt zich tussen pagina’s 62 en 63 . 


\section{De iconografie van de geleerde vrouw: toen en nu}

$\mathrm{Na}$ een wat aarzelende aanloop nam het vrouwelijk geleerdenportret in de achttiende eeuw een vlucht. Een van de eerste vrouwen die als onbetwiste autonome wetenschappelijke autoriteit werd verbeeld, was entomologe en kunstenares Maria Sibylla Merian (1647-1717). ${ }^{35}$ Haar gedrukte portret - gegraveerd door Jacobus Houbraken (1698-1780) - werd opgenomen in zowel de Nederlandse als Latijnse uitgave van haar populaire Rupsenboek en daarnaast als losse prent verspreid en verzameld. De voorstelling, die terugging op een tekening die haar schoonzoon Georg Gsell ad vivum (naar het leven) van haar maakte, getuigde van een nauwgezette compositorische hand die optimaal gebruik maakte van bestaande beeldvormingsmechanismen om de wetenschappelijke autoriteit van de geportretteerde visueel te onderstrepen. (afb. 8) Een vergelijking met het portret van haar voorganger, natuuronderzoeker Georg Everhard Rumphius (1627-1702), dat mogelijk als directe inspiratiebron diende, maakt inzichtelijk hoezeer Merians beeltenis was bedoeld om te beklemtonen dat zij qua intellectueel vermogen en wetenschappelijke prestaties niet onderdeed voor haar mannelijke collegae. ${ }^{36}$ (afb. 9) Zowel in de gekozen setting als in de houding en gebaren van de geportretteerden zijn de afbeeldingen sterk gelijkvormig. Beide wetenschappers zijn verbeeld in driekwartaanzicht, gezeten achter een werktafel; de rechterhand reikend naar de voorwerpen van hun studies. Net als Rumphius is Merian omringd met objecten die haar geleerdheid benadrukken: drie boeken - mogelijk haar bloemenboek, het rupsenboek en haar Metamorphosis insectorum Surinamensium - een inktpot met veer, de tekeningen van schelpen, bloemen en insecten, een vergrootglas, hemelglobe, en, vanzelfsprekend, een plant met vlinder.

Afgezien van haar evidente vrouwelijke voorkomen, herinnerde slechts een element aan de unieke weg die Merian als vrouw had moeten afleggen om haar wetenschappelijke prestaties mogelijk te maken. Op de stenen pot aan de rechterzijde van de voorstelling herkende de oplettende beschouwer de mythologische figuren van

35 Over Merians leven en loopbaan, alsmede haar portret, zie ook: N. Zemon Davis, Women on the Margins. Three Seventeenth-Century Lives, Cambridge MA 1995, pp.140-202; C. Pick, Rhetoric of the Author Presentation: the Case of Maria Sibylla Merian (ongepubliceerd proefschrift), Austin 2004.

36 Meerdere frontispices die werden vervaardigd voor het werk van Merian waren geënt op het werk van Rumphius. Vergelijk bijvoorbeeld de gegraveerde titelpagina voor Rumphius' populaire De Amboinsche Rariteitenkamer (1705) - waarvoor ook Merian nog enkele prenten vervaardigde - met het frontispies die Schijnvoet vervaardigde voor de Latijnse vertaling van Merians Rupsenboek (1718). 


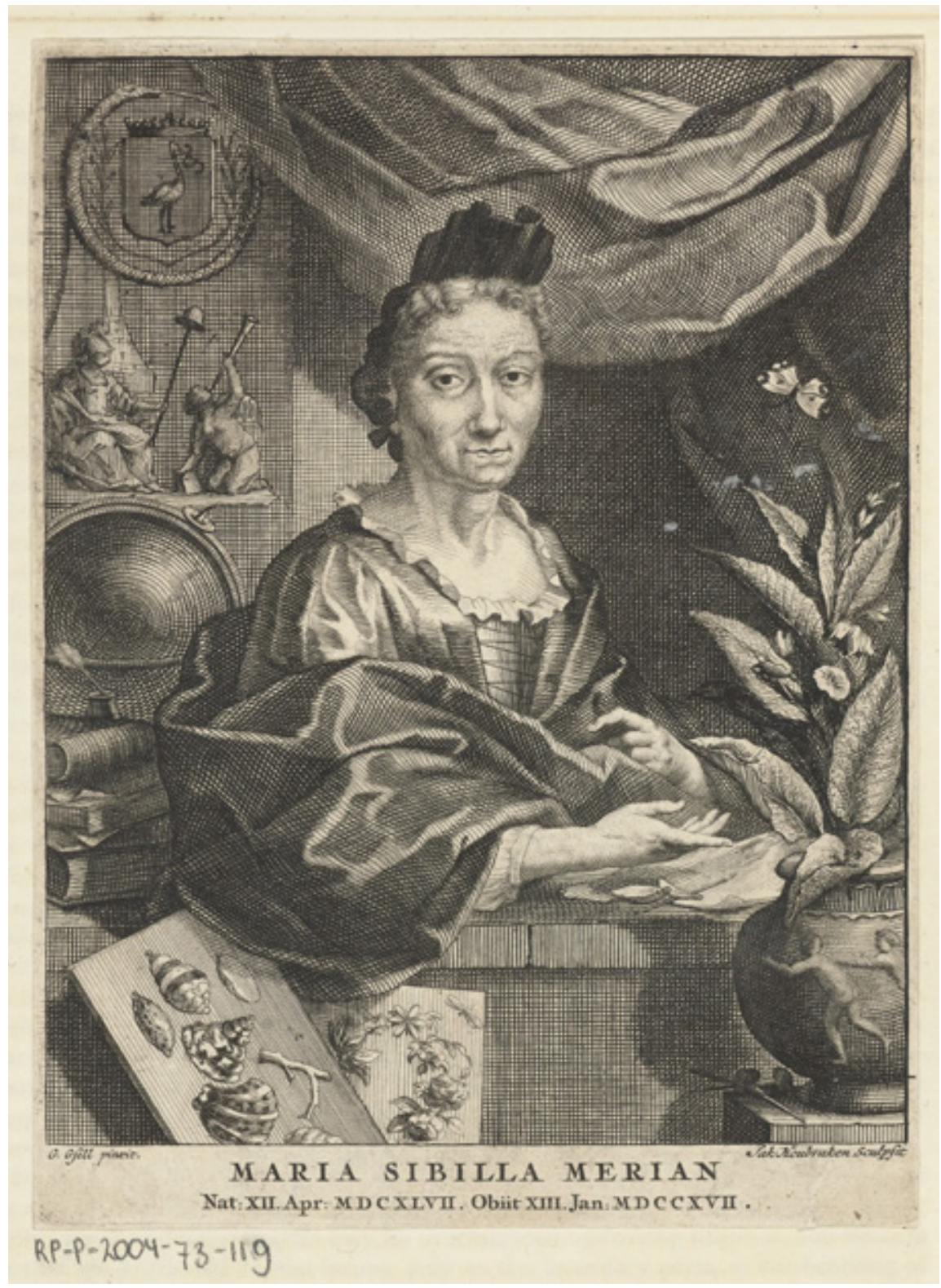

8. Jacobus Houbraken (naar Georg Gsell), Portret van Maria Sibylla Merian, 1708-1780, gravure. Rijksmuseum Amsterdam, inv.nr. RP-P-2004-73-119. 


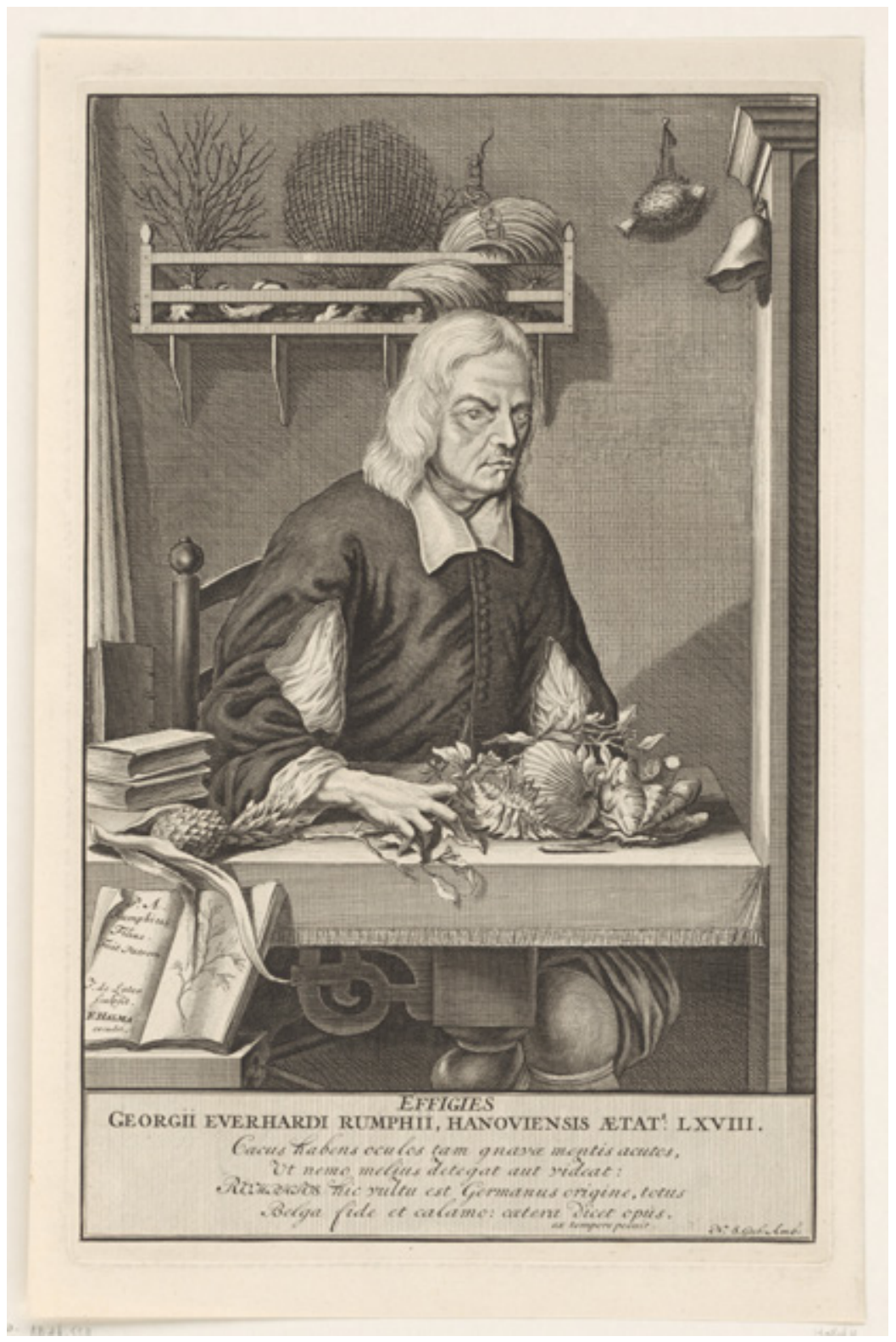

9. Jacob de Later (naar Paul August Rumpf), Portret van Georg Everhard Rumphius, 1696, gravure. Rijksmuseum Amsterdam, inv.nr. RP-P-OB-46.529. 
Daphne die achtervolgd wordt door de god Apollo. Om te ontkomen aan diens wellustige greep, verandert de nimf in een laurierboom. De voorstelling refereerde aan een onconventionele keuze die Merian maakte om haar wetenschappelijke activiteiten mogelijk te maken. In 1692 scheidde zij - na reeds jaren in afzondering te hebben doorgebracht - van haar echtgenoot, om enkele jaren later met haar jongste dochter naar Suriname te vertrekken en haar onderzoek naar planten en insecten te vervolmaken, zoals Rumphius overigens eerder op Ambon had gedaan. Daphnes transformatie tot laurierboom symboliseert dus Merians metamorfose van dochter en echtgenote tot onafhankelijke vrouw en wetenschappelijke autoriteit, die haar beschouwer zelfverzekerd in de ogen aankijkt.

Merians beeltenis is exemplarisch voor de wijze waarop portretten van vrouwelijke geleerden vanaf de vroegmoderne tijd ingezet werden als vehikel in de strijd tegen de stereotiepe beeldvorming van de geleerde als man. Ruim drie eeuwen later blijken nog altijd vergelijkbare beeldvormingsmechanismen gebruikt te worden om de wetenschappelijke autoriteit van vrouwelijke geleerden te onderstrepen. Zo kreeg het succesvolle fotoproject in de Senaatszaal van de Universiteit Leiden een meer structureel vervolg toen in 2018 de portretten van dertien mannelijke hoogleraren uit de vaste portrettengalerij werden vervangen door dertien eigentijdse gezichten van vrouwelijke hoogleraren. (afb. 10) De schilderijen, die in nauwe samenspraak met de geportretteerden werden geconcipieerd, volgden in hoofdlijnen de traditionele opzet die het Leidse geleerdenportret reeds vanaf de achttiende eeuw typeerde: de voorstellingen zijn omkaderd door een statige zwarte lijst met aan bovenzijde steeds de naam van de geportretteerde in goudgelige kapitalen en aan de onderzijde, in Latijn, diens geboorteplaats en -datum, gevolgd door de academische functie en de tijdsspanne waarin deze werd vervuld.

Net als Merian lieten deze eigentijdse vrouwelijke geleerden zich vereeuwigen met veelbetekenende iconografische elementen: de grote graafmachine van archeoloog Corrie Bakels (middelste rij; vijfde van links); het anatomisch model van een hart dat teder wordt vastgehouden door ontwikkelingsbioloog Christine Mummery (onderste rij, derde van links) en het lijvige boek waaruit classicus Ineke Sluiter (onderste rij, zesde van links) in overpeinzing opkijkt, staan elk symbool voor het wetenschappelijke veld waarin deze vrouwen zich begaven. Een enkeling greep de voorstelling aan om het eeuwenoude vrouwelijke bescheidenheidstopos bewust te doorbreken door openlijk de erkenning die zij ontving voor haar wetenschappelijke verdiensten te omarmen. Letterkundige Mineke Schipper-de Leeuw (bovenste rij, zesde van links) liet zich bijvoorbeeld zelfbewust afbeelden met de onderscheiding tot Officier in de Orde van 


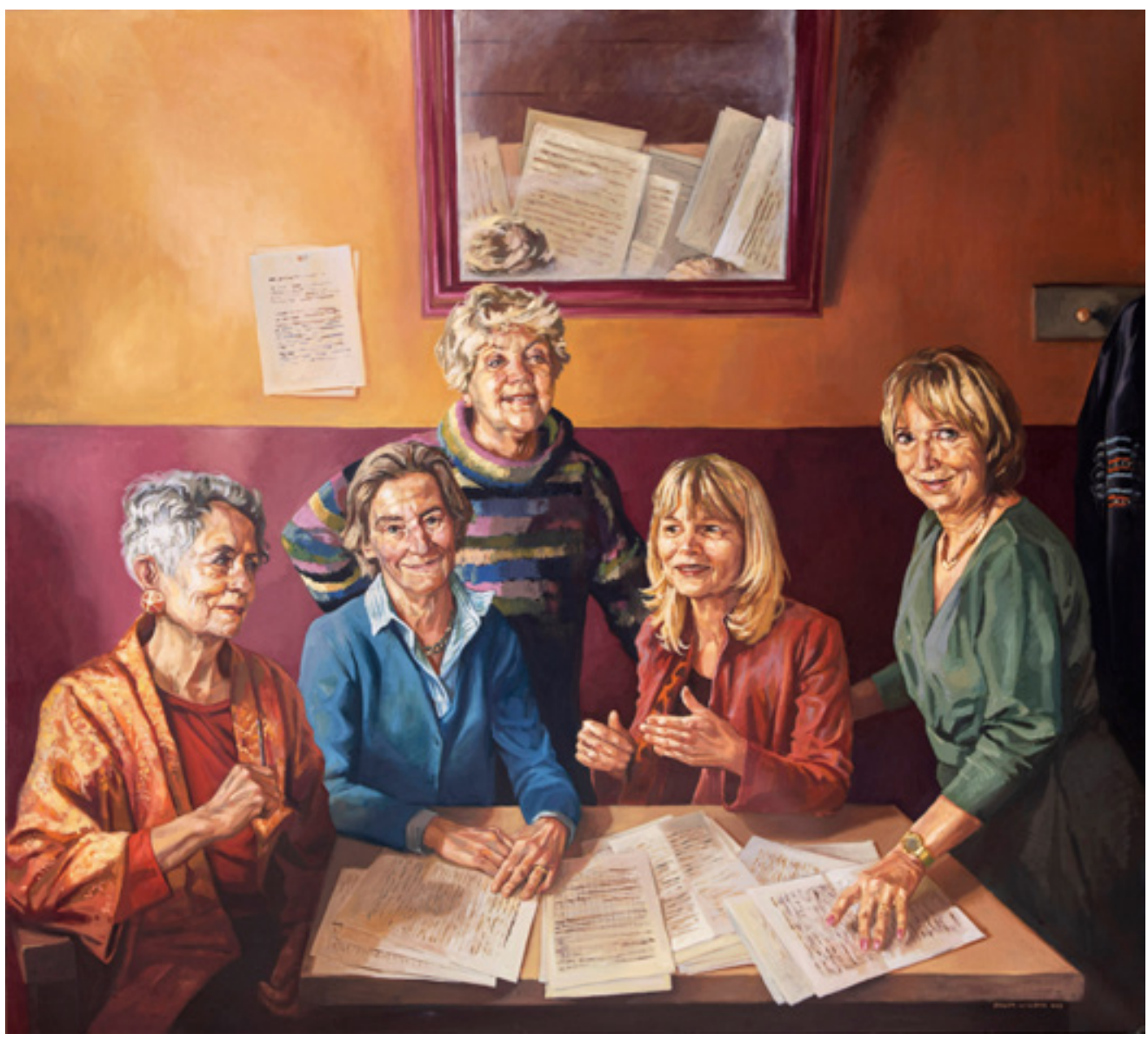

11. Rogier Willems, vijf vrouwelijke hoogleraren, 2019, schilderij. V.I.n.r. zijn de Amsterdamse hoogleraren Mieke Bal, Anne van Grevenstein-Kruse, Aafke Hulk, José van Dijck en Marita Mathijsen afgebeeld (Foto: Bob Bronshof).

\section{Een blijvende balansoefening}

De dertien nieuwe vrouwenportretten in de Leidse Senaatszaal illustreren hoe eeuwenoude representatiestrategiëen ingezet worden om vrouwelijke intellectuele autoriteit te verbeelden. Dat portretten van geleerde vrouwen vandaag nog altijd aanleiding kunnen geven tot discussies over de vrij gecompliceerde en vaak meerduidige beeldvorming van vrouwelijke intellectuele autoriteit, blijkt uit de kritische reacties die volgden op het 
Groepsportret van vijfvrouwelijke hoogleraren dat in mei 2019 onthuld werd in de hal van het Bushuis van de Universiteit van Amsterdam. In opdracht van de faculteit geesteswetenschappen, vereeuwigde kunstenaar Rogier Willems vijf prominente vrouwelijke hoogleraren in een groepsportret. (afb.11) 'De Staalmeesteressen', zoals het schilderij - vanwege de met Rembrandts iconische werk corresponderende afmetingen - in de wandelgangen ook wel wordt genoemd, verbeeldt de vrouwen in overleg rond een tafel. Aan de kapstok tegen de achterwand ontwaart de toeschouwer een UvA-toga. De spiegel tegen de muur reflecteert waar het werkelijk om gaat: een veelheid aan paperassen als symbool voor het intellectuele gedachtegoed van deze vrouwen.

Met het portret beoogde, zo lichtte decaan Fred Weerman toe in een interview met Het Parool, de faculteit te visualiseren dat de UvA niet langer een mannenbolwerk is en tegelijkertijd te voorzien in het gebrek aan 'vrouwelijke rolmodellen' aan de muren van de universiteit. ${ }^{38}$ Hoewel deze uitgangspunten naadloos aansluiten bij de eerdere, en enthousiast ontvangen, initiatieven om binnen de muren van universiteiten kwesties rond genderdiversiteit aan de hand van portretten aan te kaarten, vond niet iedereen deze voorstelling geslaagd. In een ingezonden stuk in De Volkskrant met de programmatische titel 'UvA, schilder deze theekrans snel over', deed een Amsterdamse studente haar beklag over het vrouwbeeld dat in verf was gevangen. ${ }^{39}$ De voorstelling liet bij haar eerst en vooral de indruk van een 'kiekje van een high tea' achter, waarbij de representatie van 'kennis, kunde, of wetenschap' overschaduwd werd door associaties met woorden zoals ' $g e z e l l i g$, huisvrouwen, en knus'. Als zodanig, zo concludeerde zij, doet het schilderij 'geen recht aan de waarde die deze vrouwen hebben voor de Universiteit'. Ditmaal geen vermeend erotische lading, zoals nog het geval was bij Van Schurman, maar de doorwerking van meer recente vooroordelen en huiselijkheidsidealen. Maar in beide gevallen speelden heersende sociaal-maatschappelijke motieven een sturende rol in de be- of veroordeling van het beeld van de geleerde vrouw(en) in kwestie.

38 R. Khaddari, 'Vijf prominente vrouwelijke hoogleraren van de UvA geportretteerd', in: Het Parool, 9 mei 2019.

39 S. de Vries, 'UvA, schilder deze theekrans snel over, want dit doek doet geen recht aan de waarde die deze vrouwen hebben voor de universiteit', in: De Volkskrant, 28 mei 2019. Op dit stuk volgde een reactie van Mieke Bal, een van de geportretteerde hoogleraren, zie: M. Bal, 'Groepsportret is allesbehalve "kiekje van een theekransje"', in: De Volkskrant, 3 juni 2019. 
De reacties die werden uitgelokt door de recente onthulling van de 'Staalmeesteressen', laten ons achter met de wat ontluisterende constatering dat deze beeldvormingsproblematiek diep verankerd zit in de manier waarop nog altijd naar vrouwelijke geleerden wordt gekeken. De commotie maakt eens te meer duidelijk hoezeer de waardering van hun portretten na vier eeuwen nog altijd in sterke mate gestuurd wordt door heersende sociaal-maatschappelijke verwachtingspatronen en associaties. Systematisch historisch onderzoek naar de representaties van (aspirant) vrouwelijke geleerden kan deze hedendaagse beeldvormingskwestie in perspectief plaatsen door inzichtelijk te maken hoe in het verleden (al dan niet effectief) is geprobeerd de stereotiepe beeldvorming van de wetenschapper als man te doorbreken. Als zodanig levert historisch onderzoek inkijk in de langlopende mechaniek achter beeldvorming. Dat juist portretten - en bij verbreiding portrettengalerijen - nog altijd worden aangegrepen om de stereotiepe representatie van de wetenschapper aan te kaarten, is in dit opzicht veelzeggend voor de fundamentele historische dimensie van het probleem. Wat vergelijkende studie van dergelijke portretten uit verleden en heden en de reacties die zij ontlokten bij tijdgenoten alvast wel laat zien, is hoe effectief het vrouwelijk geleerdenportret er steeds in slaagt om ogenschijnlijk moeizaam te verenigingen sociaalmaatschappelijke categorieën - namelijk vrouw en geleerd - te versmelten in een beeld en zodoende heersende stereotypes ter discussie te stellen. We zullen echter moeten afwachten of het medium van het geleerdenportret daadwerkelijk in staat is om fundamentele verandering te bewerkstellingen in het stereotiepe beeld. Vrouwelijke geleerdenportretten als ondubbelzinnige 'spiegels van Sophia' - onbetwiste reflecties van vrouwelijke wetenschappelijke autoriteit - lijken ook nu nog altijd een stap te ver.

Lieke van Deinsen is als postdoctoraal onderzoeker (FWO) en docent verbonden aan de afdelingen Kunstwetenschappen en Nederlandse Letterkunde van de KU Leuven. Ze werkt momenteel aan een studie over de beeldvorming van vrouwelijke geleerden in vroegmodern Europa. Ze promoveerde op Literaire erflaters. Canonvorming in tijden van culturele crisis (Verloren 2017). Eerder verscheen van haar ook The Panpoëticon Batavûm. The Portrait of the Author as a Celebrity (Rijksmuseum 2016). 


\title{
Het Plakkaat van Verlatinge (1581) in het Nederlandse herdenkingsjaar 2018
}

\author{
Historici versus dagbladpers
}

\begin{abstract}
Anton van der Lem
Naar aanleiding van de grote tentoonstelling '80 jaar oorlog' in het Rijksmuseum, buigt Anton van der Lem zich over de vraag waarom men in Nederland behoefte heeft aan nieuwe feestelijke herdenkingen van deTachtigjarige Oorlog. Door onder andere te focussen op hedendaagse verwijzingen naar het Plakkaat van Verlatinghe, laat hij zien hoe begrijpelijk maar toch ook problematisch het is om gebeurtenissen uit de Tachtigjarige Oorlog - die in haar vroege stadia een burgeroorlog was - te vieren in een nieuwe nationale feestdag in het Koninkrijk der Nederlanden.
\end{abstract}

$\mathrm{V}$ eel leden van de Vlaams-Nederlandse Vereniging waren aanwezig bij de feestelijke opening van de tentoonstelling ' 80 jaar oorlog' in het Rijksmuseum te Amsterdam op 11 oktober 2018. Het was de eerste grote overzichtstentoonstelling in het Rijksmuseum die niet aan een kunsthistorisch maar aan een zuiver historisch onderwerp was gewijd. Aanleiding vormde de herdenking van de zogeheten Slag bij Heiligerlee (23 mei 1568), waarmee men in Nederland traditioneel de 'Tachtigjarige Oorlog' laat beginnen. Het uitgangspunt was niet om Nederland binnen de huidige staatsgrenzen centraal te stellen, maar juist de Nederlanden als geheel, zoals Karel V ze in 1555 overdroeg aan zijn zoon Filips II. De oorlog werd nadrukkelijk gepresenteerd als een internationaal conflict. In plaats van het nationale epos, zo negentiende-eeuws, beklemtoonde de tentoonstelling het karakter van de Opstand als burgeroorlog in de Lage Landen. Daarbij kwam bovendien duidelijk tot uitdrukking dat de loop der gebeurtenissen altijd een heel andere had kunnen zijn: de rol van het toeval was heel groot en er was geen dwingend voorschrift waarom de scheiding in de Lage Landen zo 
verliep zoals ze verlopen is. Dat was ook de mening van Peter Vandermeersch in zijn groot opiniërend artikel op 6 oktober 2018 in NRC Handelsblad: 'Het had zo anders kunnen lopen'.

De samensteller van de tentoonstelling in het Rijksmuseum - conservator en historicus Gijs van der Ham - heeft terecht veel lof geoogst voor zijn benadering. Hij herleidde de talloze feiten en ontwikkelingen tot op de hoofdlijnen en essentiële gebeurtenissen en gaf die weer in korte, kernachtige begrippen: orde, chaos, verdreven, breuk etc. Waardering was er voor de het feit dat de tentoonstelling zich niet beperkte tot de beginperiode, de jaren van de Opstand, maar de hele Tachtigjarige Oorlog aan de orde stelde. Kortom: de organisatie weerspiegelde in de tentoonstelling hoe er vandaag de dag onder historici in Nederland, België en andere landen over het belang van deze oorlogsperiode in de geschiedenis van Europa wordt gedacht. Over de kwaliteit en uniciteit van tal van voorwerpen kon men zich alleen maar verbazen en verheugen.

\section{Voorgeschiedenis}

De Opstand in de Nederlanden is eigenlijk een heel verkeerde term. Degenen die bezwaar maakten, protesteerden en vervolgens zich verzetten tegen de absolutistische politiek van Filips II wensten helemaal niet in opstand te komen. Zij bleven gehecht aan de traditioneel in acht genomen politieke gebruiken in de Nederlanden: de landsheer bestuurt zijn gewesten overeenkomstig hun eigen belang, waarvoor zij gehoord worden in de gewestelijke Statenvergaderingen. Hij (eventueel zij) zal bijvoorbeeld geen oorlog voeren of belastingen heffen zonder hun instemming. Daarnaast of daarboven dient de Raad van State bij belangrijke kwesties haar advies te mogen geven. De belangen van de gewesten in de Nederlanden mogen niet ondergeschikt gemaakt worden aan andere bezittingen van de vorst. Deze bepalingen en vele anderen waren samengevat in de zogeheten Blijde Inkomste, bevestigd door de hertog van Brabant op 3 januari 1356. Dit document is geleidelijk beschouwd als een soort grondwet voor alle Lage Landen, waarop eerst de hertogen van Brabant en later de hertogen van Bourgondië de eed aflegden wanneer zij werden ingehuldigd. ${ }^{1}$ Men zou de stelling kunnen wagen dat zij al-

1 Het voorbeeld van Brabant gold bijvoorbeeld ook voor de stadsrechten van de Brabantse steden, die van Leuven en Den Bosch op Haarlem en Delft en vandaar op de andere Hollandse steden overgingen. J. Huizinga, 'De opkomst van Haarlem' (1905/o6), in:Idem, Verzamelde werken, 9 dln., Haarlem 1948-1953, I, pp.203-364, speciaal pp.300-341. 
len - misschien alleen met uitzondering van Karel de Stoute - deze Blijde Inkomste hebben willen naleven. Filips II was echter een heel ander vorst en beschouwde zich - mede als koning van Spanje en heerser over de door Spanje gedomineerde gebieden - als een absoluut vorst, die zijn gezag uitsluitend aan God dankte en niet (mede) uit handen van het volk ontving. Van begin af aan moet hij deze eedsaflegging als een formaliteit, als een stukje folklore hebben willen beschouwen. In de loop van de zestiende eeuw kwam daar een geweldig probleem bij: de reformatie. Filips II wenste onverkort vast te houden aan het rooms-katholieke geloof en geen andere godsdiensten in zijn rijken toe te laten. De leider van de oppositie in de Lage Landen, prins Willem van Oranje, sprak zich principieel uit voor de vrijheid van godsdienst en geweten in de vergadering van de Raad van State in Brussel op 31 december 1564: hoewel goed katholiek kon hij niet goedkeuren dat vorsten wensten te heersen over het geweten van hun onderdanen en hen de vrijheid van geloof wilden ontnemen. ${ }^{2}$ Gezien tegen het licht van de Blijde Inkomste was gehoorzaamheid in de Lage Landen iets anders dan gehoorzaamheid in Spanje. De hertog van Alva, een van Filips' belangrijkste adviseurs, stelde algauw dat er maar eens wat hoofden in de Lage Landen moesten rollen. Na de ongeregeldheden van 1566 met het Verbond der Edelen en de Beeldenstorm was hij het die met een leger de orde in de Nederlanden moest herstellen, waarna de koning zelf zou komen om in zijn natuurlijke goedertierenheid de Nederlanden te laten delen. De graaf van Egmond, aanvankelijk medestander van Willem van Oranje, koningsgezind en katholiek, vroeg in zijn naïviteit hoe hij de koning het best kon dienen en kreeg als enig antwoord: door te gehoorzamen. Nog op het schavot meende hij begenadigd te zullen worden. Oranje zag scherper: Filips II wenste uitsluitend zelf te regeren en geen concessies te doen, noch politiek, noch godsdienstig. Gaf de koning al eens toe, dan liet hij geestelijken of notarissen vastleggen dat hij zijn woord niet hoefde te houden omdat hij onder dwang had gehandeld. Tot op de dag van vandaag moeten zowel in België als in Nederland regeringen op basis van coalities tot stand komen, op basis van overleg; in Spanje daarentegen blijft coalitiepolitiek uit den boze en worden er doorgaans minderheidsregeringen gevormd.

2 Vgl. A. van der Lem, De Opstand in de Nederlanden 1568-1648. De Tachtigjarige Oorlog in woord en beeld, Nijmegen 2018, pp.7-10. 


\section{Unie van Utrecht en Plakkaat}

Als in 1579 de anti-Spaanse gewesten en steden zich aaneensluiten in de Unie van Utrecht, dan beschouwen zij nog steeds de koning als de rechtmatige landsheer, dus als hertog van Brabant, van Gelre etc., graaf van Holland, Zeeland, Vlaanderen enz. Zij beklagen zich erover in de Unie-tekst dat de koning de beloften niet nakomt die hij bij zijn Blijde Inkomst en inhuldiging gedaan had. ${ }^{3}$ Op 6 augustus 1579 gaat de calvinistische stadsrepubliek Gent nog een stap verder en zet deze Filips II eenvoudigweg af, zonder van plan te zijn aan een andere vorst te denken. ${ }^{4}$

Elke kenner van dit spectaculaire tijdperk in de geschiedenis van de Nederlanden erkent het belang van het Plakkaat van Verlatinge, van 26 juli 1581. Dit was een verklaring waarmee de gewesten en steden die de politiek van Filips II niet konden aanvaarden hem in 1581 als landsheer 'verlieten', oftewel afzetten. Het denkbeeld zich daarmee 'onafhankelijk' te verklaren was nog ver weg. Integendeel: door Filips II te 'verlaten' wilden ze juist de mogelijkheid hebben om de soevereiniteit aan een andere landsheer aan te bieden, iemand die wel zou willen luisteren naar wat zij hun belangen achtten, bijvoorbeeld door steun te zoeken bij de vorstenhuizen van Frankrijk of Engeland. ${ }^{5}$ Met name Willem van Oranje, de onbetwiste leider van de opstandelingen, was van mening dat de strijdende provincies het zonder hulp van buiten niet zouden kunnen redden. De Duitse lutherse vorsten waren niet in beweging te brengen. Maar de prins van Oranje had van oudsher goede contacten met het Franse koningshuis en de hoge Franse adel. ${ }^{6}$ De hertog van Anjou, Frans van Valois (1555-1584), was een broer van de Franse koning Hendrik III (1551-1589) en had zowel politiek als militair regelmatig een eigen koers gewaagd. Zou hij bereid gevonden kunnen worden om de zaak van de eerste eed had afgelegd in 1549 en bij zijn inhuldiging in 1555. in Flanders and Brabant', in: H. Koenigsberger (red.), Republiken und Republikanismus im Europa der frühen Neuzeit, München 1988, pp.145-154, aldaar p.146.

5 J. Pollmann, 'The Cult and Memory of War and Violence', in: H.J. Helmers \& G.H. Janssen (red.), The Cambridge Companion to the Dutch Golden Age, Cambridge 2018, pp.87-104, citaat op p.89.

6 J. van Tol, 'William of Orange in France and the Transnationality of the SixteenthCentury Wars of Religion', Bijdragen en Mededelingen betreffende de Geschiedenis der Nederlanden, $134 \cdot 4$ (2019), pp.33-58. 
Nederlanden op zich te nemen ${ }^{7}$ Om de moeizame onderhandelingen tussen deze Franse prins en de Nederlandse gewesten te begunstigen, was er op maandag 15 mei 1581 in Zeeland een vast- en biddag uitgeschreven. ${ }^{8}$ Willem van Oranje had al zijn overtuigingskracht nodig om de Staten van Brabant en die van Vlaanderen ertoe over te halen Anjou als hun hertog, respectievelijk hun graaf te erkennen en in te huldigen. De Staten van Holland en Zeeland echter weigerden dit en bleven direct onder de 'Hoge Overheid' van Willem van Oranje. Een volgeling van Anjou nam desondanks zijn kans waar door een bestaand boek met prenten van alle graven van Holland en Zeeland opnieuw uit te laten geven, waaraan hij de hertog van Anjou als graaf van Holland en Zeeland liet toevoegen en afbeelden!9 (afb. 1)

De politiek met Anjou liep op een compleet fiasco uit en kostte Willem van Oranje het grootste deel van zijn populariteit. Na hun beider dood (respectievelijk 10 juni en 10 juli 1584) zagen de Staten-Generaal geen andere mogelijkheid dan opnieuw de soevereiniteit aan Frankrijk aan te bieden. De toenmalige koning Hendrik III wees dit echter af, uit de terechte vrees dat hem dit in

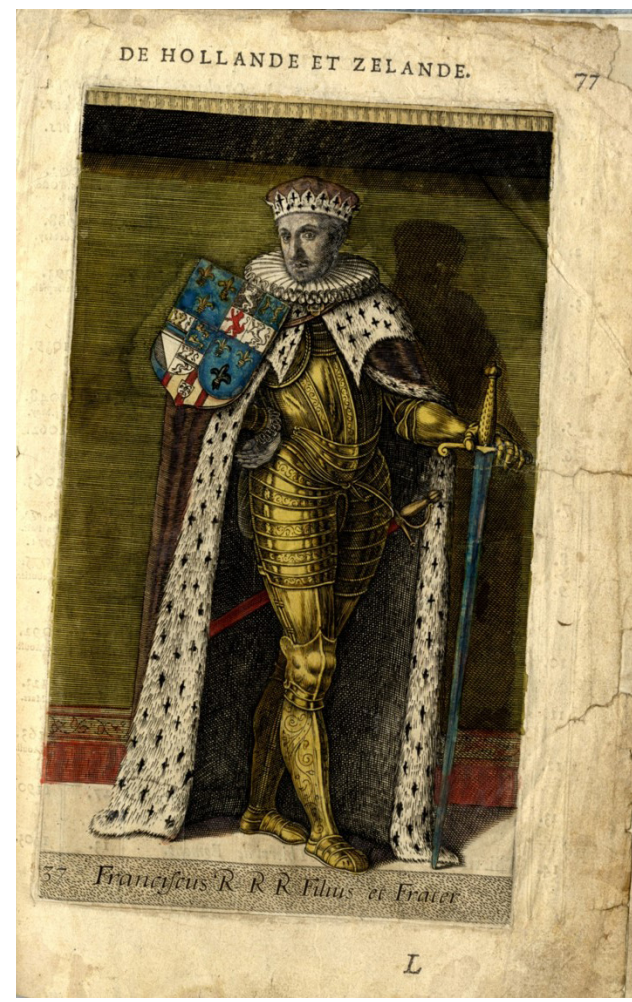

1. Frans van Valois, hertog van Anjou (1555-1584), in: Michiel Vosmeer, Les vies et alliances des Comtes de Hollande et Zelande, Seignevrs de Frise, Antwerpen 1583. Universiteitsbibliotheek Leiden inv. Nr. 21182 E 85. oorlog zou brengen met Spanje. Dit was immers

$7 \quad$ F. Duquenne, L'entreprise du duc d'Anjou aux Pays-Bas de 1580 à 1584. Les responsabilités d'un échec à partager, Villeneuve d'Ascq 1998.

8 F. van Lieburg, Een eiland na de Reformatie: Schouwen-Duiveland 1572-170o, Amsterdam 2011, p.157.

9 De oorspronkelijke editie was: Michael Vosmeer, Principes Hollandiae et Zelandiae, domini Frisiae, Antwerpen 1578, dat de portretten van alle graven bevat tot en met Filips II. Hiervan verscheen een bewerking in het Frans, 'imitées et tirées du Latin par N. Clément de Tresles, secrétaire de son Altesse, La vie et alliances des Comtes de Hollande et Zelande (Anvers, 1583). Son Altesse slaat duidelijk op Anjou, wat Oranje had als hoogste titel Son Excellence. 
precies dat wat de Staten-Generaal hoopten. Daarna vestigden de Staten-Generaal hun hoop op de Engelse koningin Elisabeth. Deze hield al helemaal niet van rebellen, maar vreesde de invloed van Frankrijk in de Lage Landen meer dan die van Spanje. Dat haar hulptroepen de zaak van de Opstand kwamen ondersteunen stelden de Staten-Generaal op prijs, mits de majesteit zich niet met de binnenlandse politiek van de opstandige gewesten bemoeide. Of zoals haar minister Walsingham het eens overbriefde: 'Those towns want to have a lord to obey them, and not to obey him'.10 Nadat zij dat wel had proberen te doen, trokken de Staten van de Nederlandse gewesten in 1588 de soevereiniteit naar zichzelf en daarmee is dit jaar als het beginjaar van de Nederlandse onafhankelijkheid te beschouwen, hoe prematuur ook, en niet het jaar van het Plakkaat. Toen 25 jaar na het Plakkaat in 1606 Oldenbarnevelt de gedachte aan vrede met Spanje begon te opperen omdat de strijd niet meer vol te houden leek, zag ook hij maar één alternatief voor vrede: het aanbieden van de soevereiniteit aan een andere mogendheid, dat wil zeggen door het aanbod te herhalen dat destijds aan Anjou was gedaan, ditmaal aan koning Hendrik IV van Frankrijk (1553-1610)!11 Hoezo, onafhankelijkheid van Nederland? Het Plakkaat van Verlatinge is een tussentijds hamerstuk geweest in de vergadering van de Staten-Generaal van de 'Gheunieerde Nederlanden'. De afgevaardigde heren zijn niet gaan staan om een eed af te leggen. Weliswaar is het plakkaat in het Nederlands en het Frans gepubliceerd (afb. 2 en 3), maar men bazuinde het besluit niet uit. In de eerste plaats om niet onder eigen volk onrust op te roepen. Hoewel de vorst ver weg was en boer en burger in de praktijk alleen met het eigen directe bestuur van stad of streek te maken hadden, beschouwden veel mensen de koning als hun soeverein. De Staten-Generaal wilden de gevoelens van deze mensen ontzien. Bovendien wilden de Staten niet hun lucratieve, overzeese handel op Spanje in gevaar brengen. Daarmee was het een besluit meer voor binnenlands dan voor buitenlands gebruik, laat staan dat die samengestelde natie, die de 'Gheunieerde provinciën' vormden, zich op de borst sloeg en zich onafhankelijk verklaarde. Internationaal had het Plakkaat ook geen enkel effect: buiten de Nederlanden bleven de buitenlandse vorsten de koning van Spanje als de gebieder en het staatshoofd van de Lage Landen zien. Daaraan kwam formeel pas

Van der Lem, Opstand, p.213.

11 Archives ou correspondance inédite de la maison d'Orange-Nassau, G. Groen van Prinsterer (red.), Deuxième série. 2 tom., Utrecht 1857-1858, brief van de Franse gezant De Buzanval, nr. 338, pp.369-37o. 


\section{Jande Staten Genetad bande Gbyeunieerbe ßederlanden.}

\section{BYDEN VVELCKEN, MIDTS DEN.}

REDENEN IN'T LANGHE IN'T SELFDE begrepen, men verklaert den Coninck van Spagnien vervallen vande Overheyt ende Heerfehappije

van defe vooriz. Nederlaniden, Ende verbiet zijnen Naem ende Zegel inde felve Landen meer te ghebruycken. \&c.

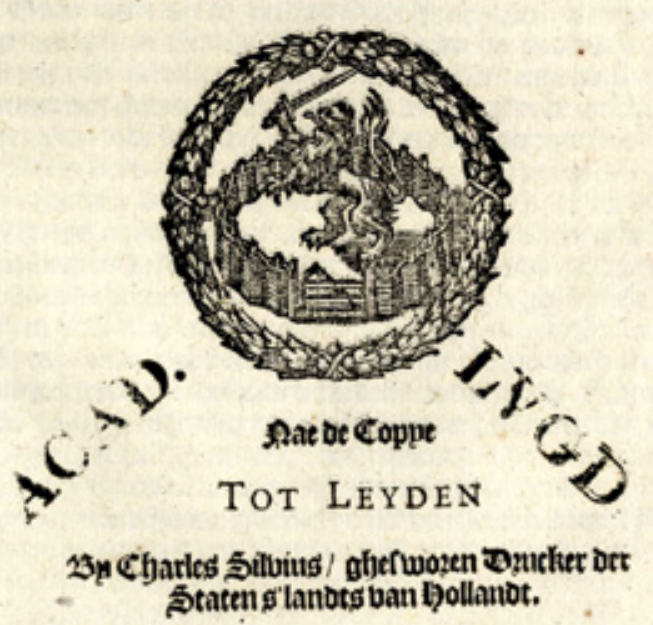

M. D. IXXXI.

2. Placcaert vande Staten Generael vande Gheunieerde Nederlanden, byden welcken, midts den redenen in't langhe in't selfde begrepen, men verclaert den coninck van Spaegnien vervallen vande overheyt ende heerschappije van dese voors. Nederlanden, ende verbiet sijnen naem ende zeghel inde selve Landen meer te ghebruyckn, \&c. Universiteitsbibliotheek Leiden THYSPF 476. 


\section{PLACCART DES}

\section{EST A TS GENERA VX \\ DES PROVINCES VNIES \\ DV PAIS BAS.}

\section{PAR LEQVEL (POVR LES}

raifons en iceluy au long contenuës) on declare le Roy d'Efpaigne eftre decheu de la feigneurie \& principauté de ces Païs: \& fe defend de plus vfer d'ores-en-auát de fon nom \& feau és mefmes Pays-bas, \&c.
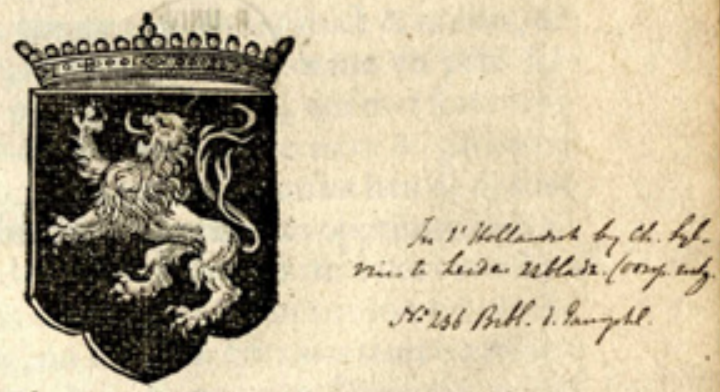

A A N V ER $s$,

En l'Imprimerie de Chriftofle Plantin;, par commandement des Eftats.

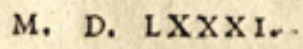

3. Placcart des Estats Generavx des Provinces Vnies dv Pais Bas : par leqvel ... on declare le roy d'Espaigne estre decheu de la seigneurie \& principauté de ces païs; \& se defend de plus vser d'ores-en-avant de son nom \& seau és mesmes Pays-Bas, \&c. Universiteitsbibliotheek Leiden PAMFLT 1581: 12 
een einde met de Vrede van Münster in 1648, toen Filips IV van Spanje de soevereiniteit van de Nederlandse Republiek erkende, waarna de andere mogendheden volgden.

Toch valt er een initiatief te vermelden uit de tijd van de Tachtigjarige Oorlog zelf om de dag waarop tot het Plakkaat van Verlatinge besloten was tot een gedenkdag te maken. Dit idee werd gesuggereerd door predikanten op het Zeeuwse eiland Tholen in 1637, het jaar waarin Frederik Hendrik Breda heroverde. Bij alle militaire successen en economische welvaart waarop de Republiek kon bogen, waren volgens deze predikanten de mensen vergeten waar het werkelijk om ging:

Alzo men bevindt dat de eerste beginselen van onze oorlog en de gronden van die, de wonderlijke opgang van onze staat en de grote zegeningen en weldaden, die wij onder onze regering niettegenstaande de gruwelijke tirannie en machinaties van de koning van Spanje hebben ontvangen, bij de gemeente alle dagen meer en meer vergeten, ja nauwelijks meer gedacht worden [...]

Daarbij hadden ze natuurlijk in de eerste plaats het oog gericht op de strijd tegen het rooms-katholicisme. In de vergadering van de Zeeuwse classes, de vertegenwoordigers van alle gereformeerde gemeenten in de provincie, stelden zij voor om de dag van de 'afzwering' van de Spaanse koning jaarlijks te herdenken en wel op de eerste zondag na de bewuste datum van 26 juli. Deze herdenking zou uiteraard in de gereformeerde kerk moeten plaatsvinden, met gebed en dankbaarheid en ver van kermissen en ander zondig feestgedruis. Maar de Zeeuwse synode van 1638, waar het voorstel had moeten worden besproken, maakt geen gewag van het idee. ${ }^{12}$

\section{Twee presentaties}

In het herdenkingsjaar 2018 - 450 jaar na de Slag bij Heiligerlee - had men op 26 juli de keuze uit het bijwonen van twee presentaties van een uitgave van het Plakkaat. In de bibliotheek van de Universiteit Leiden, gesticht door Willem van Oranje en de Staten van Holland in 1575, vond de aanbieding plaats van een nieuwe druk van de wetenschappelijke uitgave, al in 2006 uiterst zorgvuldig verzorgd door de Leidse hoogleraar Nicolette Mout, kenner van onder andere de Nederlanden in de zestiende 
eeuw. ${ }^{13}$ Op diezelfde dag werd in het gebouw van de Eerste Kamer in Den Haag de 'uitgave' gevierd van de Nijmeegse classicus Anton van Hooff. ${ }^{14} \mathrm{Al}$ op 7 februari $2 \mathrm{O} 8$ had deze gelegenheidshistoricus in NRC Handelsblad het Plakkaat geafficheerd als de onafhankelijkheidsverklaring van Nederland en bepleit dat 26 juli een nationale feestdag moest worden. Op zich is het natuurlijk een mooi streven om deze fundamentele episode in de geschiedenis van de Nederlanden jaarlijks te herdenken. Er is immers geen gebeurtenis in die lange oorlog die in Nederland landelijk wordt herdacht. In de weinige plaatselijke herdenkingen komt tot uitdrukking hoe versnipperd en over het hele land verspreid deze strijd zich heeft afgespeeld. In de Zuid-Hollandse havenstad Den Briel komt men jaarlijks op 1 april in actie om te herinneren aan de inname van de stad door de Watergeuzen op 1 april 1572. In de Noord-Hollandse stad Alkmaar herdenkt men op 8 oktober dat op die dag in 1573 het koninklijke leger de belegering van de stad opgaf. Het was voor de eerste keer dat er een einde kwam aan de militaire successen van de Spanjaarden in de Lage Landen: 'bij Alkmaar begint de victorie'. Nog grootser viert Leiden in Zuid-Holland elk jaar op 3 oktober het ontzet van de stad door de troepen van de prins op die dag in 1574. Het zijn gebeurtenissen die tot de verbeelding spreken, maar die mede in de belangstelling bleven door de sterk 'Hollandocentrische' gerichtheid in het geschiedenisonderwijs in Nederland.

Zodra het om zijn eigenlijke uitgave van het Plakkaat gaat, moet Anton van Hooff toegeven: 'Natuurlijk leunen de teksten in dit boek stevig op eerdere complete hertalingen' - zelf hertaalt hij slechts fragmenten en somt hij deze puntsgewijs op. ${ }^{15} \mathrm{Nu}$ is het van belang te weten dat Anton van Hooff een voorstander is van de republiek, en lid of sympathisant van het Republikeins Genootschap. Daar is niets mis mee, maar zie daar zijn beweegredenen. Stel je toch eens voor dat na de 'verlating' van Filips II de Staten-Generaal prins Willem van Oranje als hun nieuwe landsheer zouden hebben ingehuldigd? Zou Anton dan nog steeds geporteerd zijn voor een nationale herdenking van het Plakkaat van Verlatinge? Immers neen. Aan alle inspanningen meer aandacht te vragen voor het Plakkaat ligt bij hem en zijn medestanders de al dan niet uitgesproken wens ten grondslag dat er eens een dag mag komen waarop de huidige koning zal worden 'verlaten', met de instelling van een republiek als einddoel. In het voorbijgaan doet Anton de traditionele, al twee eeuwen bestaande formulering 'bij de

13 Het Plakkaat van verlatinge. Vertaald, ingeleid en geannoteerd door Nicolette Mout, Groningen 2018, tweede [licht gewijzigde] druk (eerste druk: 2006).

14 A. van Hooff, Het Plakkaat van Verlatinge. De eerste onafhankelijkheidsverklaring, Bussum 2018, p.26.

15 Ibid, p.16 n. 2. 
gratie Gods koning der Nederlanden' af als een 'fossiel'. Nee, dan de Belgische koning - die heeft een 'mandaat van zijn volk, hij is: "Koning der Belgen".'16

Zijn uitgave heeft veel afbeeldingen dankzij de website van het Rijksmuseum, maar deze zijn rijp en groen zonder commentaar afgedrukt. Op het omslag staat een historiserend schilderij uit de negentiende eeuw, waarbij de afgevaardigden ten onrechte een eed zweren. In een van zijn eerdere ingezonden stukken in NRC Handelsblad heeft Anton van Hooff eens geponeerd dat de vraag monarchie of republiek eigenlijk een gevoelskwestie is: men is op emotionele gronden hetzij voor, hetzij tegen en past vervolgens zijn argumenten aan. Eindelijk een verstandig woord, maar het heeft met een echt historisch bewustzijn niets meer van doen.

Het Plakkaat kreeg door toedoen van Anton van Hooff grote aandacht in de dagbladpers, die mogelijk heeft bijgedragen tot de uitroeping van het Plakkaat tot 'Pronkstuk van Nederland'. Deze actie genoot de ferme steun van het Nationaal Archief in Nederland, dat de bewaarplicht voor het document heeft en op deze manier het Plakkaat onder de aandacht van een breder publiek wilde brengen. Daar kunnen universitaire vakhistorici natuurlijk kritisch op zijn of zelfs meesmuilend over doen in hun ivoren torens. Anderzijds kunnen we het Archief ook gewoon van harte feliciteren dat het in zijn opzet is geslaagd. Niet de microscoop van Anthonie van Leeuwenhoek of Rembrandts Nachtwacht heeft het gehaald, maar het Plakkaat. Dat is op zich geen kleinigheid, juist omdat het om een toch moeilijke tekst gaat. Wie nu op de website van het Archief nadere informatie zoekt, vindt slechts heel basale gegevens. ${ }^{17}$ In Nederland fronsten de geschoolde historici de wenkbrauwen en haalden ze vervolgens de schouders op. In België en/of Vlaanderen schoot de verkiezing van het Plakkaat tot Nederlands 'pronkstuk' in het verkeerde keelgat van Marc Reynebau in de Standaard. De druktemakers van de dagbladpers tegenover het bezonken oordeel van de geschoolde historici.

Het bezoek van president Obama aan Nederland in 2014 was een uitgelezen kans om het Plakkaat nog eens extra in het zonnetje te zetten. Met veel tamtam liet men het stuk overbrengen uit het Nationaal Archief in Den Haag naar het Rijksmuseum in Amsterdam. Daar hadden de president, de premier en de directeur een vrolijk fotomoment boven het document, geafficheerd om zijn voorbeeldfunctie voor de Amerikaanse Declaration of Independence uit 1776. Maar ook in de Verenigde Staten van toen

16 Ibid, p.26.

17 'Pronkstuk van Nederland: stem op het Plakkaat van Verlatinge!', https://www.nationaalarchief.nl/beleven/nieuws/pronkstuk-van-nederland-stem-op-het-plakkaat-vanverlatinge (geraadpleegd op 11 augustus 2020). Het Plakkaat trok 49 procent van de stemmen, maar hoeveel stemmen er zijn uitgebracht is niet vermeld. 
waren er verschillende meningen. John Adams, tweede president van de Verenigde Staten, had een jaar na de onafhankelijkheidsverklaring zijn zoon John Quincy Adams aangeraden om de Declaration te vergelijken met 'above all others [...] the history of the Flemish [sic] Confederacy, by which the seven United Provinces [sic] emancipated themselves from the domination of Spain'. ${ }^{18}$ Maar toen Adams zelf in de jaren 1780-1781 met de Republiek van toen te maken kreeg, kon hij geen wijs uit de politieke situatie: 'Waar in hemelsnaam berust de soevereiniteit in deze staat? Wie draagt verantwoordelijkheid? Hoe worden dingen besloten?'19

\section{Eerdere aandacht voor het Plakkaat}

Een belangrijke bundel artikelen over het Plakkaat in de breedste zin van het woord verscheen in 2011 onder de titel: The Act of Abjuration: Inspired and Inspirational. Twaalf echte experts uit Noord en Zuid en van daarbuiten stelden tal van aspecten rond het Plakkaat aan de orde, zonder daar een hedendaags politiek streven aan te verbinden. ${ }^{20}$ In hetzelfde jaar stelde ook de Franse historica Blandine Kriegel het Plakkaat aan de orde in La République et le Prince moderne. Hierin beklemtoonde zij het belang van Franse medestanders van Oranje en Opstand als Hubert Languet, Philippe Duplessis-Mornay, François Hotman en anderen. ${ }^{21}$ Een echte uitgave van het Plakkaat is dan weer te vinden in een bundel onder de veelbelovende titel De geboortepapieren van Nederland. Voorafgaand aan het Plakkaat bevat dit boek de teksten van de Unie van Utrecht en de Apologie van prins Willem van Oranje, gekarakteriseerd als 'Drie teksten die staan voor het revolutionaire karakter van de Opstand en die als een bom insloegen, die evenwel niet uit de lucht kwamen

18 Geciteerd in: S.E. Lucas, 'The Act of Abjuration as a Model for the Declaration of Independence: Thomas Jefferson and the Art of Imitation', in: P. Rood \& R. Kubben (red.), The Act of Abjuration: Inspired and Inspirational. Twelve authors on One of the Highlights of the Nationaal Archief of the Netherlands, Den Haag \& Tilburg 2011, pp.172-189, aldaar p.181.

19 Geciteerd in: J. Verheul, De Atlantische pilgrim. John Lothrop Motley en de Amerikaanse ontdekking van Nederland, Amsterdam 2017, p.121.

20 Zie noot 18. Met bijdragen van o.a. Hans Cools, Liesbeth Geevers, Simon Groenveld en Violet Soen.

21 B. Kriegel, La République et le Prince moderne: les Français et la naissance des ProvincesUnies, Parijs 2011. 
vallen en die illustreren hoe een natie werd geboren.'22 Een koningskroontje voor in het boek, '20o jaar monarchie' en de naam Elsevier maken duidelijk dat de uitgave getuigt van de belangstelling voor 'het ontstaan van Nederland' en daarmee van een eenzijdige blik op de zestiende eeuw. De 'proloog' rammelt aan alle kanten en mag ons verzekeren van het goede Nederlanderschap van de inleiders, maar niet van hun kennis van zaken. ${ }^{23}$

Als tegenwicht tegen deze nationale afbakening van de geschiedenis, noem ik de inspanningen van de Prins Willem de Eerste Herinneringsstichting. Deze zet zich in om monumenten op te richten ter herinnering aan Willem van Oranje in die plaatsen waar de prins zich heeft laten gelden. Daarbij gaat het om plaatsen in de Nederlanden zelf, zowel in Antwerpen als in Leiden en Leeuwarden, maar ook in Dillenburg en Parijs. ${ }^{24}$ Op 9 oktober 2019 onthulde prinses Beatrix een meer dan manshoog staand monument van de prins in de Hofstraat te Dordrecht. ${ }^{25}$ De Dordtse locatie herinnert aan het feit dat op aansturen van de prins de stad Dordrecht in 1572 de eerste 'vrije' Statenvergadering bijeengeroepen had. Daarbij waren niet alleen de zes traditionele steden uitgenodigd, maar elke stad die het streven van Staten en prins ondersteunde. ${ }^{26}$ Bij die gebeurtenis besloten de Staten de prins weer als hun stadhouder te erkennen

22 De geboortepapieren van Nederland. De Unie van Utrecht, de Apologie van Willem van Oranje en het Plakkaat van Verlating in hedendaags Nederlands. Ingeleid en geduid door Coos Huijsen en Geerten Waling, Amsterdam 2014, p.14. De vertalingen in hedendaags Nederlands zijn door drie verschillende heren gemaakt, niet door de beide redacteuren, wat niet aan de consistentie bijdraagt.

23 Willem van Oranje wordt hier weer Willem de Zwijger genoemd, p.19: 'deed Willem ('de Zwijger') er tactisch het zwijgen toe' en Marnix als de auteur van het Wilhelmus beschouwd (pp.19-20). Oldenbarnevelt heet in één adem 'landsadvocaat en raadpensionaris [...] van de Staten van Holland (p.32), kennelijk overgenomen van Wikipedia. Oldenbarnevelt bekleedde het ambt van landsadvocaat van Holland (vanaf 6 maart 1586); na zijn tragisch einde kreeg zijn functie de benaming raadpensionaris (zonder s) en werd de inhoud van de functie scherp omschreven.

24 Liberté et Tolérance: een sculptuur van Willem van Oranje in Parijs, Parijs 2016. Met bijdragen van Ger Luijten, Willem Frijhoff, Alastair Duke en Coen Tamse.

25 C. Tamse (red.), Willem van Oranje en de Eerste Vrije Statenvergadering 1572 Dordrecht, Den Haag 2019. Met bijdragen van Wouter Kolff en Piet Sleeking, Judith Pollmann, Jan Teeuwisse en Coen Tamse.

26 De traditionele zes: Dordrecht, Haarlem, Delft, Leiden, Amsterdam en Gouda. Van deze zes ontbraken Delft en Amsterdam. De wel deelnemende steden zijn op de sokkel genoemd, van links naar rechts (zonder rekening te houden met de anciënniteit van het stadsrecht): Dordrecht, Alkmaar, Enkhuizen, Hoorn, Gorinchem, Medemblik, Gouda, Edam, Haarlem, Leiden en Monnickendam. De burgermeester van Oudewater was bij de onthulling diep bedroefd, want zijn stad was ten onrechte niet vermeld. 
en hem veel geld ter beschikking te stellen om gewapend de strijd aan te gaan tegen de slechte raadgevers van de koning en de Spaanse troepen. Nog niet tegen de koning zelf! Willem van Oranje gaf daarmee aan dat hij, anders dan de koning, wel de Staten van het gewest bij zijn bestuur betrok.

Meer dan twintig jaar geleden mocht ik in de Universiteitsbibliotheek Leiden een website beginnen over de Opstand in de Nederlanden. Uiteraard heb ik onder het hoofdstuk Bronnen meteen de tekst van het Plakkaat opgenomen. ${ }^{27}$ In die twintig jaar bleef de herkomst van de bezoekers stabiel: 78 procent van de bezoekers kwam uit Nederland, 12 procent uit België (Vlaanderen wordt nog niet afzonderlijk gerubriceerd) en de overige 10 procent zijn ongeveer gelijkelijk verdeeld over de Verenigde Staten, het Verenigd Koninkrijk, Frankrijk, Duitsland en Spanje. Gelukkig is er nu de Vlaams-Nederlandse Vereniging die ons bijeen brengt om elkaar te vinden of met elkaar van mening te verschillen. Dat is een groot goed en zo hoort het ook.

\section{Een Benelux-dag?}

Aan het streven een herdenkingsdag uit de Tachtigjarige Oorlog als 'nationale' feestdag voor Nederland in te stellen, mogen we wel eens de vraag stellen of dit nog wel van deze tijd is. Zou het niet veel beter zijn geen feestdag, maar een gedenkdag in te stellen waarbij het hele toenmalige gebied van de Nederlanden wordt betrokken? Een dag die als een Benelux-dag zou kunnen worden gememoreerd, een dag waarbij de banden tussen Nederland en België (dus met inbegrip van Wallonië) zouden kunnen worden aangehaald? Want de Tachtigjarige Oorlog heeft een einde gemaakt aan de gemeenschappelijke geschiedenis van beide landsdelen, hoe onsamenhangend het geheel ook was. Men zou kunnen denken aan de herdenking van de Blijde Inkomste of Joyeuse Entrée (tweetalig!) van 3 januari 1356, waarbij een nieuwe landsheer de eed op de bestaande instellingen en bepalingen aflegde. Een gebeurtenis karakteristiek voor alle gewesten. En Blijde Inkomste klinkt zoveel positiever dan een Verlatinge. Niet dat ik denk dat zoiets onder brede lagen van de bevolking veel weerklank zal vinden, maar het zou voor onze bestuurders in Noord en Zuid een bezinning kunnen zijn op de gemeenschappelijke belangen die de Lage Landen in de Europese Unie hebben. Geen achterom kijken naar de splitsing, maar een vooruitblik op de gezamenlijke toe-

27 'Plakkaat van Verlatinghe' (bron), https://dutchrevolt.leiden.edu/dutch/bronnen/ Pages/1581\%2007\%2026\%20ned.aspx (geraadpleegd op 11 augustus 2020). 
komst, juist als 'Europa' mocht stagneren. Het denkbeeld dat België zou 'verdampen' in Europa is niet voor vandaag of morgen. België is Europa, wat met de benoeming van de Belgische minister-president Charles Michel tot voorzitter van de Europese Raad andermaal is bewezen - de Nederlanders staken en steken in dat opzicht bleek af bij het succes van de Belgen. Laten we samen bruggenbouwers zijn onderling en tussen de drie grote landen om ons heen - samen hebben we meer te winnen dan elk afzonderlijk.

Anton van der Lem is historicus en auteur van De Opstand in de Nederlanden 1568-1648. De Tachtigjarige Oorlog in woord en beeld, vertaald in het Engels en Duits. Hij is de initiatiefnemer en eindredacteur van https://dutchrevolt.leiden.edu en als Scaliger Fellow verbonden aan de Universiteitsbibliotheek Leiden. 



\title{
In de voetsporen van de meesters
}

\author{
Rembrandt, Rubens en hun museumhuizen \\ in Amsterdam en Antwerpen*
}

\author{
Hans Cools
}

\begin{abstract}
In deze bijdrage bespreekt en vergelijkt Hans Cools de cultus van Rembrandt en de cultus van Rubens zoals die in de negentiende eeuw in respectievelijk in Amsterdam en Antwerpen ontstonden. In beide steden ijverden gezagsdragers, erfgoedprofessionals en historici voor de erkenning van deze twee zeventiende-eeuwse schilders als exponenten van hun vadersteden, ja zelfs hun 'natie'. Hun initiatieven leidden uiteindelijk tot de oprichting van het Rembrandthuis en het Rubenshuis. Hans Cools laat zien dat de organisatoren van dergelijke heldenvereringen elkaars stappen bestudeerden en imiteerden. Hun praktijken leidden tot maatschappelijke en wetenschappelijke discussies over historische authenticiteit en de verondersteld correcte museale presentatie van de levens en werken van deze twee beroemde schilders.
\end{abstract}

\section{Rembrandt en Rubens als magneten voor toeristen}

I n 2019 was het precies driehonderdvijftig jaar geleden dat Rembrandt van Rijn overleed. De citymarketeers van het NBTC (Nederlands Bureau voor Toerisme en Congressen) zagen er een uitstekende gelegenheid in om toeristen te lokken. Onder de noemer 'Rembrandtjaar' ontwierpen zij een samenhangend programma waarin onder andere plaats was voor blockbuster-tentoonstellingen in Amsterdam, Den Haag, Leeuwarden en Leiden. Die strategie werkte. Alleen al het Rijksmuseum trok dat jaar, in niet geringe mate dankzij de twee Rembrandt-tentoonstellingen die het

* Mijn dank gaat uit naar de twee anonieme referenten en vooral ook naar Stefaan Grieten (Vlaams Architectuurinstituut/ KU Leuven), Simon Richter en Liliane Weissberg (beiden University of Pennsylvania) die eerdere versies van dit artikel becommentarieerden en tal van suggesties deden. Uiteraard ben ik verantwoordelijk voor de resterende onvolkomenheden. 
toen organiseerde, 2,7 miljoen bezoekers. Dat was meer dan ooit tevoren. Ook het Rembrandthuis liet zich niet onbetuigd: daar liepen kort na elkaar zelfs drie verschillende tentoonstellingen. Deze opzet van het NBTC was niet nieuw. Eerder al had het Bureau een Van Goghjaar (2015) en een Mondriaanjaar (2017) geëntameerd. ${ }^{1}$

Het kennelijk succes van het NBTC ging niet aan de concullega's van de Vlaamse Dienst voor Toerisme voorbij en dus zetten zij het programma 'Vlaamse Meesters' op. ${ }^{2}$ Dat liep van 2018 tot en met 2020 en daarbij stonden achtereenvolgens Rubens, Breugel en Van Eyck centraal. Voor Pieter Breugel geldt dat het in 2019 vierhonderdvijftig jaar geleden was dat hij was overleden. In december van datzelfde jaar werd ook de jarenlange en ingrijpende restauratie van Jan Van Eycks absolute meesterwerk Het Lam Gods voltooid. Enkele weken later ging in Gent de rond hem opgezette tentoonstelling 'Een optische revolutie' van start. Maar voor Pieter Paul Rubens ontbrak in 2018 een dergelijke kapstok. Die was klaarblijkelijk ook niet nodig. De organisatoren van het Antwerpse stadsfestival dat toen rond zijn oeuvre werd georganiseerd stelden eenvoudigweg dat 'Rubens inspireert'. ${ }^{3}$

Zowel voor Rembrandt als voor Rubens geldt dus dat zij als magneten voor toeristen fungeren. Hun faam is sterk verbonden met die van hun vadersteden, respectievelijk Amsterdam en Antwerpen. Beide kunstenaars zijn dan ook in het Nederlandse, respectievelijk Vlaamse collectieve geheugen verankerd. Zo hebben hun tot musea getransformeerde woonhuizen, waarover hieronder meer, zowel in de Nederlandse als in de Belgische Lieux de mémoire-bundels een eigen lemma gekregen. ${ }^{4}$ Bij een bre-

1 G. Pama, 'Het Rembrandtjaar was een succes, nu verder met de Gouden Eeuw', in: NRC Handelsblad, 29 december 2019. Meer over het belang van Rembrandt voor de Amsterdamse city-marketing bij M. de Waard, 'Rembrandt on Screen. Art Cinema, Cultural Heritage, and the Museumization of Urban Space, in: idem (red.), Imagining Global Amsterdam. History, Culture, and Geography in a World City, Amsterdam 2012, pp.143-148.

2 Meer informatie is te vinden op: https://www.flemishmasters.com/nl/\# (geraadpleegd 20 augustus 2020).

3 Cf. https://www.toerismevlaanderen.be/nieuws/vlaamse-meester-rubens-inspireertantwerpen-barok (geraadpleegd $2 \mathrm{O}$ augustus 2020).

4 M. Prak, 'Amsterdam: Rembrandthuis. Inleiding', in: idem (red.)., Plaatsen van herinnering. Nederland in de zeventiende en achttiende eeuw, Amsterdam 2006, pp.16-23 en H. Cools, 'Antwerpen: Het Rubenshuis. Hoe artistieke grootheid wordt opgeroepen', in: J. Tollebeek e.a. (red.), België, een parcours van herinnering. I. Plaatsen van geschiedenis en expansie, Amsterdam 2008, pp.137-149. Voor een analyse van het concept 'Lieux de mémoire' en een vergelijking tussen de Nederlandse en de Belgische bundels zie het essay van J. Tollebeek, 'Vaut le voyage'. De Belgische plaatsen van herinnering', pp.13-25 in laatstgenoemde bundel. 
der publiek roepen hun namen dan weer uitgesproken sentimenten op. Rembrandt, met zijn verondersteld liederlijke levensstijl en zijn voorkeur voor verkleedpartijen en personages aan de zelfkant van de samenleving, verbeeldt het rommelige en het onvolmaakte. ${ }^{5}$ Bij Rubens daarentegen horen etiketten als exuberant en weelderig; hij verpersoonlijkt barok. ${ }^{6}$

\section{Rubens en Rembrandt: parallelle levens, spiegelbeeldige reputaties?}

Ook (kunst)wetenschappers besteden, nu zij steeds meer aandacht krijgen voor de persoonlijkheden van de artiesten die zij bestuderen, opnieuw aandacht aan dergelijke reputaties. ${ }^{7}$ Daarbij hoort onlosmakelijk de vraag in welke mate Rembrandt door Rubens werd beïnvloed. Zo stelde Simon Schama dat Rembrandts tomeloze ambitie voortkwam uit diens obsessie met Rubens' roem. Het leverde, hoewel de titel Rembrandt's Eyes anders doet vermoeden, een vuistdikke dubbelbiografie van beide schilders op. ${ }^{8}$ De veronderstelde wedloop van Rembrandt met Rubens bracht de eerste in ieder geval weinig geluk. Aan het eind van zijn leven stond Rembrandt in veel lager aanzien bij zijn tijdgenoten dan voor Rubens drie decennia eerder had gegolden. Op Aert de Gelder na, had Rembrandt toen ook geen leerlingen meer. Velen beschouwden hem als een mislukte kunstenaar. Bovendien was Rembrandt in 1658 failliet verklaard. Tot aan zijn levensavond, elf jaar later, worstelde hij met de afbeta-

5 B. Bakker, 'De stad in beeld. 't Was of 'k mijzelven vond. Het stadsgezicht als spiegel van de tijd', in: M. Bakker e.a. (red.), Amsterdam in de tweede Gouden Eeuw, Amsterdam 2000, p.105.

6 B. Deseure e.a., 'Rubensmania. De complexe constructie van cultuur in heden en verleden', in: I. Bertels, B. De Munck \& H. Van Goethem (red.), Antwerpen. Biografie van een stad, Amsterdam \& Antwerpen 2010, pp.179-181 en 205-208. Niet toevallig keerde het epitheton 'barok' ook terug in de titel van het stadsfestival dat in 2018 rondom de kunstenaar werd georganiseerd. Zie ook noot 2.

7 Zie bv. J. Bikker, Rembrandt. Biografie van een rebel, Rotterdam 2019, p.224.

8 S. Schama, Rembrandt's Eyes, Londen etc. 1999. Het boek is naar het Nederlands vertaald als De ogen van Rembrandt, Amsterdam 1999. Eertijds ontvingen (kunst) historici Schama's boek weinig lovend. Desondanks vond het zijn weg naar het brede publiek en is het, zowel in het Nederlands als in het Engels nog steeds verkrijgbaar. Cf. C. Vloet, 'Lekker vette woorden', in: Hollands Maandblad, nr. 626 (2000), pp.22-24. Overigens stipte E.H. Gombrich in zijn recensie aan dat hij het goed mogelijk achtte dat Rembrandt wel degelijk door Rubens' succes werd beïnvloed. Cf. diens 'Portrait of the Artist as a Paradox', in: The New York Review of Books, 20 januari 2000. 
ling van zijn schulden. ${ }^{9}$ Rubens daarentegen was zowel door de Spaanse als de Engelse koning geridderd. Bij zijn overlijden, in 1640, was hij een vermogend man die zijn echtgenote en zijn kinderen niet alleen zijn Antwerps stadspaleis maar ook een landgoed in Elewijt, halfweg tussen Mechelen en Brussel, naliet. Bovendien hielden zijn leerlingen zijn reputatie twee decennia later nog hoog, zoals blijkt uit de betrokkenheid van Jacob Jordaens in de jaren 1660 bij het decoratieprogramma van het nieuwe Amsterdamse stadhuis, tegenwoordig bekend als het Paleis op de Dam. ${ }^{10}$

Hoe dan ook, in het midden van de negentiende eeuw steeg de waardering voor Rembrandt in Amsterdam. ${ }^{11}$ Alras nam zij de trekken aan van een echte cultus die niet moest onderdoen voor de reeds langer bestaande verering van Rubens in Antwerpen. Vervolgens zouden cultuurdragers en beleidsmakers in beide steden zich laten inspireren door de keuzes die in de andere stad werden gemaakt. Daarbij was de onderlinge rivaliteit die ver in de tijd terugging nooit ver weg. In dit artikel reconstrueer ik die wederzijdse beïnvloeding door na te gaan hoe de cultus van beide meesters sinds de tweede helft van de negentiende eeuw gestalte heeft gekregen in de toen nieuwe grote Amsterdamse en Antwerpse kunstmusea en in hun respectievelijke woonhuizen. Maar vooraleer ik dat kan doen, dien ik kort de wortels van die interstedelijke rivaliteit te schetsen en moet ik nagaan waarom de cultus van schilders precies in de tweede helft van de negentiende eeuw zulk een hoge vlucht nam.

\section{Amsterdam en Antwerpen als zustersteden}

De rivaliteit tussen Amsterdam en Antwerpen kent een lange voorgeschiedenis. Zeker sinds vroege zestiende eeuw zijn de lotgevallen van beide steden met elkaar verknoopt. In die periode groeide Antwerpen uit tot de commerciële draaischijf van Noordwest-Europa. Amsterdam legde zich toen vooral toe op de doorvoer van Baltisch

9 Cf. M. Bosman, Rembrandts plan. De ware geschiedenis van zijn faillissement, Amsterdam 2019.

10 B.J. Buchbinder-Green, The painted decorations of the Amsterdam town hall, Ann Arbor 1975, pp.181-22O; W. Frijhoff \& M. Spies e.a., 1650. Bevochten eendracht, Den Haag 1999, pp.453 en 499 en E.-J. Goossens, Schat van beitel en penseel. Het Amsterdamse stadhuis uit de Gouden Eeuw, Amsterdam \& Zwolle 1996, pp.36-37, 50 \& 61-63. Voor ontleningen uit Antwerpen in het iconografisch programma aan de buitenzijde van het Paleis op de Dam zie A. Balis, 'De stroom en de zee. De iconografie van Scaldis en Neptunus in de Antwerpse kunst', in: Tijdschrift voor Geschiedenis, 123 (2010), p.519.

Bakker, 'De stad in beeld', p.105. 
graan naar het zuiden, de zogenaamde Moedernegotie. ${ }^{12}$ Aanvankelijk fungeerde de stad dan ook als een Antwerpse satelliet. ${ }^{13}$ Dat veranderde na de inname van de Scheldestad door Alexander Farnese in 1585. In de daaropvolgende jaren verlieten tal van koop- en ambachtslieden Antwerpen. Velen daarvan vestigden zich, al dan niet na enige omzwervingen, aan de Amstel. Zij droegen daar met hun kapitaal en hun kennis in niet geringe mate bij tot de start van de Gouden Eeuw. ${ }^{14}$ Amsterdam loste toen Antwerpen af als de voornaamste Europese metropool. ${ }^{15}$ Zo ontstond het beeld als zou 'de één zijn dood, de ander zijn brood' zijn geweest. ${ }^{16}$ Een kleine eeuw hield Amsterdam haar Europese koppositie vast. Vervolgens zette een lange periode van stagnatie in die aan het einde van de achttiende eeuw in een steile economische en demografische neergang verkeerde. Deze crisis hield tot ver in de negentiende eeuw aan. ${ }^{17}$

Intussen was in Antwerpen de groei opnieuw ingezet, eerst nog aarzelend als marinehaven onder Napoleon Bonaparte en vervolgens als commerciële haven dankzij de tijdelijk herstelde vrije doorvaart op de Schelde tijdens het kortstondige

12 M. van Tielhof, The 'Mother of all Trades.' The Baltic Grain Trade in Amsterdam from the Late 16 th to the early 19th Century, Leiden etc. 2002.

13 Voor de verhoudingen tussen Antwerpen en Amsterdam in de zestiende eeuw zie C. Lesger, Handel in Amsterdam. Kooplieden, commerciële expansie en verandering in ruimtelijke economie van de Nederlanden, ca.1550-ca.1630, Hilversum 2001.

14 Hoe groot de bijdrage van Antwerpse kooplieden en meer in het algemeen van migranten aan de Amsterdamse take off nu precies was, vormt nog steeds de inzet van een debat onder historici. De jongste diepgravende studie over het onderwerp is die van O. Gelderblom, Zuid-Nederlandse kooplieden en de opkomst van de Amsterdamse stapelmarkt (1578-1630), Hilversum 2000.

15 P. Burke, Antwerp, a Metropolis in a comparative perspective, Gent 1993. Voor een uitdrukkelijke vergelijking tussen de Antwerpse en de Amsterdamse bloeiperiode zie P. O’Brien e.a. eds., Urban Achievement in Early Modern Europe. Golden Ages in Antwerp, Amsterdam, and London, Cambridge etc. 2001.

16 G. Verhoeven, 'Een zoet verval. Nederlandse reizigers en hun visie op de stad aan de stroom (160o-1750), in: Tijdschrift voor Geschiedenis, 123 (2010), pp.520-533.

17 C. Lesger, 'Vertraagde groei. De economie tussen 1650 en 1730' en 'Stagnatie en stabiliteit. De economie tussen 1730 en 1795', in: W. Frijhoff en M. Prak (red.), Geschiedenis van Amsterdam. II-2 Zelfbewuste stadsstaat, 1650-1813, Amsterdam 2005, pp.21-87 en 219-265 en H. Diederiks, Een stad in verval. Amsterdam omstreeks 180o, demografisch, economisch, ruimtelijk, Amsterdam 1984. 
Verenigd Koninkrijk der Nederlanden. ${ }^{18}$ Die groei werd in Amsterdam wel degelijk als concurrentie gevoeld. ${ }^{19}$

Maar na 1850 gingen de lotgevallen van beide steden weer parallel lopen. In 1863 kocht de Belgische regering de Scheldetol af. Zo nam zij de belemmeringen die de Nederlandse Republiek sinds 1585 en na 1830 het koninkrijk op de vrije doorvaart van de rivier hadden gelegd weg. ${ }^{20}$ Vervolgens werd tussen 1877 en 1883 de rechter Schelde-oever rechtgetrokken. Daarbij verdwenen de wijken rondom het Steen en de nabijgelegen Werf, de oudste van de stad. In ruil daarvoor kwamen er nog voor de uitbraak van de Eerste Wereldoorlog vijf en een halve kilometer aanlegkade, tien dokken en drie zeesluizen. ${ }^{21}$ Vrijwel gelijktijdig kreeg Amsterdam een veel kortere en geschiktere verbinding met de open zee dan via de Zuiderzee of het Noord-Hollands Kanaal mogelijk was. Na decennia van lobbyen en plannen en elf jaar graven, werd het Noordzeekanaal op 1 november 1876 eindelijk geopend. Vervolgens steeg de aanvoer van vracht over zee naar Amsterdam op nauwelijks drie jaar tijd met 136 procent. $^{22}$

De snelgroeiende werkgelegenheid leidde er ook toe dat de bevolking in beide steden explodeerde. In Amsterdam verdubbelde zij bijna in drie decennia: van circa 259.000 in 1860 tot 430.000 in $1890 .{ }^{23}$ In Antwerpen ging het in vrijwel dezelfde periode zelfs bijna om een verviervoudiging: van ongeveer 75 .0oo inwoners in 1850 naar 280.000 in $1890 .{ }^{24} \mathrm{Al}$ die nieuwkomers moesten worden gehuisvest en dus werden

18 B. Deseure, 'Sa splendeur et sa décadence sont également célèbres. Het Scheldeverhaal als politiek instrument tijdens de Franse periode', in: Tijdschrift voor Geschiedenis, 123 (2010), p.548-552.

19 R. Aerts \& P. de Rooy, 'Hoofdstad in aanbouw, 1813-1900' in: idem (red.), Geschiedenis van Amsterdam. III. Hoofdstad in aanbouw, 1813-190o, Amsterdam 2006, p.21 en H. Greefs, 'Van formeel vrij tot tolvrij. De visies op de Scheldevaart en de positie van Antwerpen als havenstad binnen de schoot van de Antwerpse Kamer van Koophandel, 1795-1863', in: Tijdschrift voor Geschiedenis, 123 (2010), pp.559 en 562.

20 E. Van Hooydonk, Strijd om de stroom. Een politieke geschiedenis van de Schelde, Leuven 2013, pp.244-251.

21 De Smedt, Stabel \& Van Damme, 'Zilt succes', pp.122-123.

22 J.G. van Dillen, 'Een eeuw economische en sociale ontwikkeling van Amsterdam (1848-1948)', in: Idem (red.), Mensen en achtergronden. Studies uitgegeven ter gelegenheid van de tachtigste verjaardag van de schrijver, Groningen 1964, pp.498-515 en P. de Rooy, 'De geest van omverwerping. 1851-1876', in: R. Aerts \& Idem (red.), Geschiedenis van Amsterdam. III. Hoofdstad in aanbouw, 1813-1900, Amsterdam 2006, pp.352-370.

23 H. de Liagre Böhl, 'De stad bestuurd. De paarse proeftuin. Radicalisering van het Amsterdamse gemeentebeleid rond 1900', in: Bakker e.a. (red.), Amsterdam in de tweede Gouden Eeuw, p.176.

24 M. Rooses, 'Het nieuw Antwerpsch museum', in: De Gids, 55 (1891), p.476. 
in hoog tempo oude volksbuurten gesaneerd en werden er nieuwe opgetrokken. Dat gebeurde onder impuls van de stedelijke elites. Die wensten echter bovenal in een moderne stad met dito openbare gebouwen en bijhorende infrastructuur te wonen, naar de gelijkenis van metropolen als Berlijn, Parijs of Wenen. Zowel in Amsterdam als in Antwerpen kwam er dan ook een fraai, naar Engelse landschapstuinen gemodelleerd park in een nieuwe, residentiële buurt net buiten de oude stadsomwalling, respectievelijk het Vondelpark en het Stadspark. Verder verrezen tijdens de belle époque in beide steden tal van monumentale publieke gebouwen. In Amsterdam ging het onder andere om het intussen verdwenen Paleis voor de Volksvlijt, het Concertgebouw, het Centraal Station en het Hoofdpostkantoor, tegenwoordig beter bekend als winkelcentrum Magna Plaza. ${ }^{25}$ In Antwerpen werd, net zoals in Wenen langs de Ringstraße gebeurde, vooral op het tracé van de omstreeks 1860 verdwenen Spaanse omwalling gebouwd. In enkele decennia tijds kwamen daar onder andere een filiaal van de Nationale Bank, een Paleis voor Justitie, een (intussen gesloopte) schouwburg en een operahuis te staan. ${ }^{26}$ Hoewel dit voor beide steden een tamelijk willekeurige selectie is, maakt zij toch duidelijk dat in deze reeks van gebouwen niet één bouwstijl domineerde en het stadsbeeld dus een behoorlijk eclectisch aanzien kreeg. ${ }^{27}$

Maar de hardhandige modernisering waarmee al deze bouwactiviteiten gepaard gingen, riep ook weemoed op naar een harmonieus verleden. ${ }^{28}$ De cultus voor Rubens en Rembrandt die net toen grootschalige proporties aannam hielp daarbij; hij verbond het heden met het verleden. Dat blijkt bijvoorbeeld uit het werk van de eertijds gevierde opiniemaker Conrad Busken Huet (1826-1886). Kort na elkaar, respectievelijk in 1879

25 P. de Rooy, 'In het voetspoor van de radicalen, 1889-1902', in: Aerts \& De Rooy (red.), Geschiedenis van Amsterdam. III, pp.542-543.

26 I. Bertels \& H. Van Goethem, 'Vergankelijke stedelijke ruimte. De afbraak van de Spaanse omwalling in de negentiende eeuw', in: P. Lombaerde (red.), Antwerpen versterkt. De Spaanse omwalling van haar bouw in 1542 tot haar afbraak in 1870, Antwerpen 2009, pp.128-131.

27 Zie voor Amsterdam M. Wagenaar, 'De stad ontworpen. Stadsontwerp tussen wens en werkelijkheid' en V. van Rossem, 'De stad gebouwd. De oude binnenstad vernieuwd' in: Bakker e.a. (red.), Amsterdam in de tweede Gouden Eeuw, pp.9-35 en pp.36-58 en voor Antwerpen H. Van Goethem, 'Antwerpenaren in beeld: de kantelende negentiende eeuw', in: Bertels, De Munck \& Van Goethem (red.), Antwerpen, pp.327-373.

28 Cf. L. "Pil, 'Tussen lege stad en bruisende handelsmetropool. Het beeld van de Scheldesluiting in de negentiende-eeuwse romantische kunst, in: Tijdschrift voor Geschiedenis, 123 (2010), p.587 en B. Van Oostveldt \& Stijn Bussels, 'De Antwerpse wereldtentoonstelling van 1894 als ambigu spektakel van moderniteit', in: Tijdschrift voor Geschiedenis, 125 (2012), pp.4-19. 
en in 1882-'84, publiceerde hij met Het Land van Rubens en het zo mogelijk nog invloedrijkere Land van Rembrandt twee werken waarin hij beide meesters presenteerde als de belichamers van België en Nederland. ${ }^{29}$ Vooral Huets karakterisering van Rubens spreekt boekdelen. De Antwerpse schilder was, aldus Huet 'de volmaakte Belg':

Zijn naam is als een vereenigingspunt, waarin al de hoogere uitingen van het Belgisch leven elkander ontmoeten. Op Rubens kunnen de Walen zich beroepen, wanneer iemand hen verwijt, te zeer de eigenaardigheden van hun Keltisch ras te handhaven. Op Rubens de Vlamingen, wanneer hun voor de voeten wordt geworpen, dat zij te weinig hunne Germaansche maagschap verloochenen. Op Rubens alle Belgen, die aan het goed regt van hun volksbestaan gelooven. Te naauwernood heeft de geschiedenis van Europa een tweede voorbeeld aan te wijzen van zoo veel nationalen zin, aan zoo veel humaniteit gepaard, als door hem ten toon gespreid. ${ }^{30}$

\section{Standbeelden en musea}

Dat Huet Rubens zo makkelijk met België verbond, hoeft niet te verwonderen. In Antwerpen was de schilderscultus al in de vroege negentiende eeuw, niet toevallig het moment waarop, zoals ik hierboven reeds uiteenzette, de stad zich weer voorzichtig een maritieme identiteit aanmat, op gang gekomen. ${ }^{31}$ De naasting in de laatste jaren van de achttiende eeuw door Franse revolutionairen van vrijwel alle kunstschatten uit de gesloten kerken en kloosters had er een grote leemte achtergelaten. Om dat gemis op te vullen, besloten de stadsbestuurders al in 1804 een museum te openen in het voormalige Minderbroedersklooster. Veel was daar aanvankelijk niet te zien. Dat veranderde pas na Napoleons nederlaag bij Waterloo in juni 1815. Aan het eind van dat jaar keerden zesenveertig op karren geladen schilderijen als in een triomftocht naar

29 C.H. Busken Huet, Het land van Rubens. Belgische reisherinneringen, Amsterdam 1881 en idem, Het land van Rembrand. Studiën over de Noordnederlandsche beschaving in de zeventiende eeuw, Haarlem 1882-'84, 3 vols. Voor de receptie van Busken Huet zie: P.B.M. Blaas, 'De Gouden Eeuw: overleefd en herleefd. Kanttekeningen bij het beeldvormingsproces in de negentiende eeuw', in: Idem (red.), Geschiedenis en nostalgie, Hilversum 2000, pp.52-56.

30 Busken Huet, Het land van Rubens, iii-iv.

31 B. Deseure, 'Sa splendeur', pp.546-547 en L. Pil, 'De metropool herzien. De creatie van een Gouden Eeuw', in: Van der Stock (red.), Antwerpen. Verhaal van een metropool, pp.129-137. 
de Scheldestad terug. Parochiegemeenschappen die intussen weer functioneerden, kregen de uit hun kerken geroofde schilderijen terug. Maar tal van andere kerken en kloosters waren tijdens het Frans bewind niet alleen (tijdelijk) opgeheven maar ook vernield. De schilderijen die aan die instellingen hadden toebehoord kwamen in het nieuwe museum terecht en vormden er de kern van de collectie. ${ }^{32}$

Daar droegen zij naar de mening van lokale en nationale beleidsmakers bij tot de versterking van de identiteit en de legitimiteit van het nog jonge België. Zij subsidieerden het museum dan ook ruimhartig. Zo kende minister van Binnenlandse Zaken Charles Rogier (1800-1885) in 1859 Nicaise De Keyser (1813-1887) een aanzienlijke geldsom toe voor de vervaardiging van een frescocyclus die het rijke Antwerpse artistieke leven zou verbeelden. Hoewel De Keyser tegen de zin van de minister in uiteindelijk voor olieverfschilderijen koos en hij meer dan een decennium over het werk zou doen, sprak het uiteindelijke resultaat meteen tot de verbeelding. Zijn Roem van de Antwerpse kunstschool telt niet minder dan negenendertig doeken waarop alles bij elkaar honderdvijfenzeventig figuren prijken. ${ }^{33}$ Uiteraard staat Pieter Paul Rubens centraal in dit beeldverhaal. Onder het toeziend oog van stedenmaagd Antverpia geeft hij zijn zittende leermeesters en staande leerlingen toelichting bij één van zijn schetsen. Toen het Antwerpse stadsbestuur in 1875, drie jaar na de voltooiing van de cyclus, de opdracht gaf tot het bouwen van een nieuw museum vermeldde het bestek uitdrukkelijk dat De Keysers cyclus ook in de nieuwe trapzaal diende te worden getoond. ${ }^{34}$

Hoewel het nog tot 1890 zou duren vooraleer dat nieuwe museum werd opgeleverd, kwam De Keysers cyclus daar inderdaad in terecht. Net zoals de 'cultuurtempels' die eerder in de negentiende eeuw onder andere in Berlijn, Dresden en München waren opgetrokken, koos men in Antwerpen voor een kloek, neoklassiek gebouw. Maar inspiratie voor de inrichting van het museum kwam allereerst uit het enkele jaren eerder geopende Amsterdamse Rijksmuseum. ${ }^{35}$ Daar deed de lokale Rembrandtcultus intussen beslist niet meer onder voor de verering van Rubens in Antwerpen.

In Amsterdam was inmiddels inderdaad een forse inhaalslag gemaakt. Kort voor 185 o begon de Rembrandtverering er aan kracht te winnen om vervolgens in het laatste

32 H. Vlieghe, 'De voorgeschiedenis tot 1816', in: L. De Jong e.a. (red.), Het Koninklijk Museum voor Schone Kunsten Antwerpen. Een geschiedenis 1810-2007, Oostkamp \& Antwerpen 2007, pp.22-23.

33 S. Beele, 'De roem van de Antwerpse kunstschool. Een schilderijencyclus van Nicaise de Keyser', in: Dossier Tentoonstelling Nicaise De Keyser, Antwerpen 2000, pp.6-13.

34 Ibid., p.7 n. 4 .

35 M. Rooses, 'Het nieuw Antwerpsch museum', in: De Gids, 55 (1891), p.481. 
kwart van de eeuw haar volle omvang te bereiken. Toen in 1840 een standbeeld voor Rubens op de Antwerpse Groenplaats werd opgericht, kwam in Amsterdam meteen een lobby voor een soortgelijk beeld van Rembrandt op gang, al werd het ontwerp van Louis Royer (1793-1868) uiteindelijk pas twaalf jaar later gerealiseerd. ${ }^{36}$ Aansluitend bij de lobbycampagne voor een standbeeld van Rembrandt had Huets boezemvriend, Everhardus Potgieter (1808-1875) in 1844 in De Gids, het voornaamste opinieblad van die tijd, een vlammend pleidooi gehouden voor de oprichting van een nationaal museum waar de grootste kunst en geschiedenis van de natie zouden worden getoond. Tot dan toe was de Nederlandse overheid, aldus Potgieter, in deze in gebreke gebleven. Haar weigering om een echt cultuurbeleid te ontwikkelen leidde ertoe dat zij, anders dan in de buurlanden gebruikelijk was, kansen om de vaderlandsliefde van haar burgers te bevorderen onbenut liet. Zij zou daar verandering in kunnen brengen door verschillende toonaangevende collecties samen te brengen in een nieuw, waarlijk nationaal museum voor kunst en geschiedenis. ${ }^{37}$

Hoewel Potgieters pleidooi aanvankelijk weinig weerklank kreeg en hij de opening ervan niet meer meemaakte, kwam zijn gedroomde Rijksmuseum er in 1885 alsnog. ${ }^{38}$ De keuze voor een historiserende architectuur die zowel naar de middeleeuwse gemeenschapskunst als naar de burgerlijke bouwstijl in de Nederlandse steden van de Republiek verwees, riep weliswaar veel weerstand op, maar was baanbrekend. De manier om de daar verzamelde kunst te tonen was aanvankelijk al even controversieel. De zeventiende-eeuwse nationale roem werd uitgestald in een langgerekte eregalerij die uitliep op een dwars daarop geplaatste schatkamer. Die laatste staat sinds 1906,

36 V. Veen, Het Rembrandtbeeld. Hoe een kunstenaar in de 19de een nationale held werd, Amsterdam 1977.

37 E. Bergvelt, 'Nationale onverschilligheid? Schilderkunst als erfgoed in Nederland en Groot-Brittanië in de negentiende eeuw', in: R. van der Laarse (red.), Bezeten van vroeger. Erfgoed, identiteit en musealisering, Amsterdam 2005, p.102 en M. Mathijsen, Historiezucht. De obsessie met het verleden in de negentiende eeuw, Nijmegen 2013, pp.352-353.

38 E. Bergvelt, Pantheon der Gouden Eeuw. Van Nationale Konst-Gallerij tot Rijksmuseum van Schilderijen (1798-1896), Zwolle 1998 en Mathijsen, Historiezucht, pp.446-448. 
niet toevallig een Rembrandtjaar, bekend als de 'Nachtwachtzaal', maar aanvankelijk heette zij naar de schilder van dit meesterwerk de 'Rembrandtzaal'. ${ }^{39}$

Een dergelijke schatkamer ontbrak in Antwerpen, al was het maar omdat het oeuvre van Rubens niet door een vergelijkbaar iconisch schilderij wordt overheerst. Maar Rubens domineerde er wel al van bij de oplevering van het museum de eregalerij. Zo kon het publiek er niet minder dan zeven van diens grote altaarstukken, alle afkomstig uit voormalige Antwerpse kloosterkerken, bewonderen. Tevens waren ook de andere genres die de meester beoefende, zoals portretten, historiestukken en genreschilderijen, er goed vertegenwoordigd en natuurlijk ontbrak ook een selectie van schilderijen van zijn leerlingen niet. In de daaropvolgende, iets kleinere zaal ging alle aandacht naar diens meest bekende leerling, Antoon Van Dyck. ${ }^{40}$

\section{Max Rooses en de immersiestrategie}

Zowel in het Amsterdamse Rijksmuseum als in het Antwerpse Museum voor Schone Kunsten was de scenografie er dus op gericht de bezoekers te emotioneren. Zij werden als het ware meegetroond naar de eerste etage, waar ze oog in oog stonden met imposante meesterwerken. Op die manier werden zij in de doeken meegezogen, konden zij zich onderdeel gaan voelen van de afgebeelde scènes, ja zelfs denkbeeldig figureren in Rembrandts Nachtwacht of in Rubens' Aanbidding der Koningen. Het was een strategie die, afgaand op de recensies die de Antwerpse literator Max Rooses (1839-1914) bij de oplevering van beide musea in De Gids publiceerde, op instemming kon rekenen. ${ }^{41}$ Zelf paste hij die 'immersiestrategie', zoals de theaterhistorici Bram Van Oostveldt en Stijn Bussels haar in een recent artikel in het Tijdschrift voor Geschiedenis hebben

39 M. Rooses, 'Het nieuwe Rijksmuseum te Amsterdam, in: De Gids, 49 (1885), pp.283-285 en P. de Rooy, 'Het middelpunt van het vaderland, 1901-1914', in: idem (red.), Geschiedenis van Amsterdam. IV. Tweestrijd om de hoofdstad, 190o-20oo, Amsterdam 2007, pp.27-29.

40 Rooses, 'Het nieuw Antwerpsch museum', pp.495-502 en H. Todts \& M. Laenen, 'Presentatie en tentoonstellingen', in: De Jong e.a. (red.), Het Koninklijk Museum, pp.181-182.

41 Rooses, 'Het nieuwe Rijksmuseum', pp.277-291 en idem, 'Het nieuw Antwerpsch museum', pp.476-522. Cf. R. Aerts, De letterheren. Liberale cultuur in de negentiende eeuw: het tijdschrift De Gids, Amsterdam 1997, pp.396-397. Voor een biografische notitie van Rooses zie: W. Van Rooy \& M. Somers, 'Rooses, Max', in: R. de Schryver e.a. (red.), Nieuwe Encyclopedie van de Vlaamse Beweging. R-Z, Tielt 1998, pp.2658-2662. 
genoemd, ook meermaals toe. ${ }^{42}$ Zo ontwierp Rooses voor de wereldtentoonstelling van 1894 de wijk 'Oud Antwerpen', waar de in historische klederdracht gestoken bezoekers de Antwerpse Gouden Eeuw konden naspelen. Daar troffen zij ook regelmatig een als burgemeester of schutter uitgedoste Rooses aan. Al sinds 1876 was Rooses beroepshalve tevens conservator van het net tevoren door de stad Antwerpen verworven Museum Plantin-Moretus. De bezoekers konden er als het ware in de huid kruipen van de beroemde zestiende-eeuwse drukker of zich verbeelden hoe het voelde in zijn dienst letters te zetten. Het Museum was meteen een publiekstrekker. Er ging dus een aanstekelijk voorbeeld van uit.

Een soortgelijke ervaring wilde het stadsbestuur op aangeven van Rooses ook in het Rubenshuis bewerkstelligen. ${ }^{43} \mathrm{Al}$ in 188 o deed het voor het eerst een bod op het pand. Moest men immers om Rubens' genie werkelijk te doorgronden niet, net zoals eertijds de kunstenaar had gedaan, af en toe verwijlen in diens privémuseum van Oudheden? Diende men zich niet te verbeelden hoe de schilder-diplomaat hooggeplaatste bezoekers in zijn palazzo ontving om vervolgens samen met hen half afgewerkte doeken in zijn atelier te inspecteren? Die poging liep vooralsnog op niets uit. Maar de kwestie bleef sluimeren om vervolgens door vrijwel ieder nieuw college van burgemeester en schepenen te worden opgepikt. Uiteindelijk zou het nog tot 1937 duren eer de stad Antwerpen het Rubenshuis daadwerkelijk in handen kreeg en vervolgens zou ook de restauratie bijna een decennium aanslepen.

\section{Controverse in Amsterdam}

In Amsterdam was intussen in 1906 het driehonderdste geboortejaar van Rembrandt op grootse wijze gevierd. ${ }^{44} \mathrm{Net}$ als in Antwerpen vereenzelvigden de stedelijke cultuurdragers de stad er nu volop met Rembrandt. Bestuurssecretaris van de Nederlandsche Bank en feestredenaar Godfried Quack (1834-1917) verwoordde het in de Westerkerk als volgt: 'Uit de diepte van zijn kunstenaarsziel schiep de schilder (in casu Rembrandt)

42 Van Oostveldt \& Bussels, 'De Antwerpse wereldtentoonstelling', pp.4-19.

43 Zie voor de moeizame verwerving van het Rubenshuis door de stad Antwerpen en de daaropvolgende restauratie Cools, 'Antwerpen: Het Rubenshuis', pp.137-149 en P. Maclot, 'De Rubenssite: van pre-industrieel tot museale kunstenaarswoning', in: $M \mho \mho L$. Monumenten, Landschappen en Archeologie, 38.4 (2019), pp.20-33.

44 Zie voor een uitvoerige beschrijving van deze Rembrandtfeesten en verdere literatuurverwijzingen De Rooy, 'Het middelpunt van het vaderland', pp.27-29. 
zijn wonderwerken. Rembrandt en Amsterdam behoorden bij elkander. In het hart van Holland was besloten de grootste schat van Holland.' ${ }^{45}$ Naar die woorden handelde de gemeente Amsterdam. Kort tevoren had zij het Rembrandthuis aangekocht. Nu droeg zij het onder impuls van de hoogbejaarde schilder Jozef Israëls (1824-1911) over aan een daartoe in het leven geroepen stichting. Het gemeentebestuur stelde daarbij wel als voorwaarde dat het huis zou worden teruggebracht 'in de staat waarin het gedacht moet worden verkeerd te hebben toen het door de schilder Rembrandt van Rijn werd bewoond'. ${ }^{46}$ Hiertoe zocht de stichting Karel de Bazel (18691923) aan (afb. 1), toen reeds één van Nederlands meest vooraanstaande architecten, al tekende hij pas een goed decennium later zijn beroemdste creatie, het hoofdkantoor van de Nederlandsche Handel-Maatschappij (19191926) aan de Amsterdamse Vijzelgracht, tegenwoordig de locatie van het Amsterdamse Stadsarchief. ${ }^{47}$

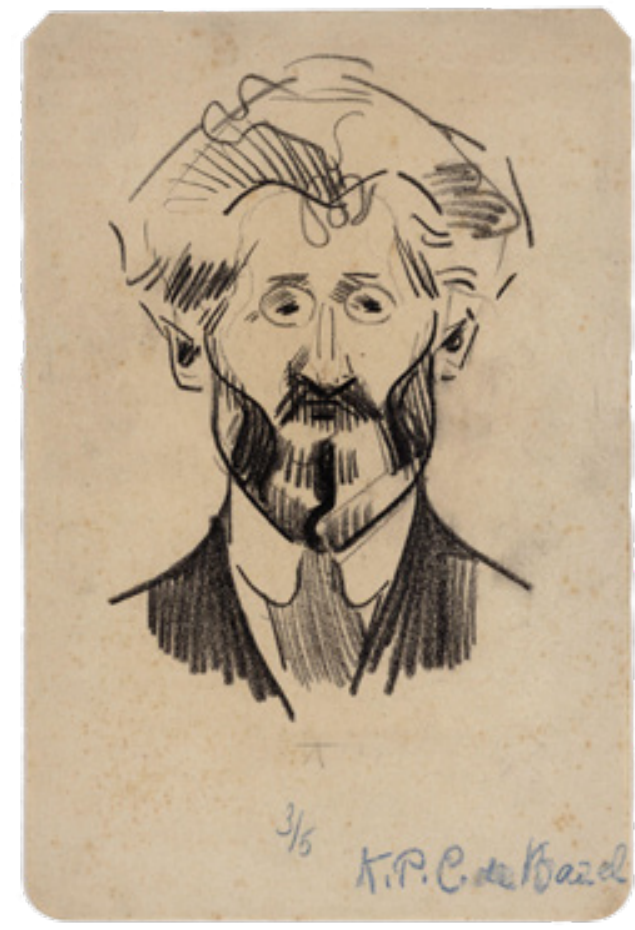

1. Portrettekening van Karel de Bazel door Martin Monnickendam uit 1915. Stadsarchief Amsterdam.

45 H.P.G. Quack, Herinneringen uit de levensjaren van mr. H.P.G. Quack, 1834-1913, Amsterdam 1915, pp.429-437.

46 B. van den Boogert, 'Het Rembrandthuis: een mooi reconstructieplan', in: Binnenstad, 168 (januari 1998), ook online beschikbaar op https://www.amsterdamsebinnenstad. $\mathrm{nl} /$ binnenstad/168/rembrandthuis.html (geraadpleegd 3 september 2020).

47 Zie voor een biografische notitie van Karel de Bazel en verdere literatuurverwijzingen: http://resources.huygens.knaw.nl/bwn188o-200o/lemmata/bwn3/bazel (geraadpleegd 11 september 2O2O). 


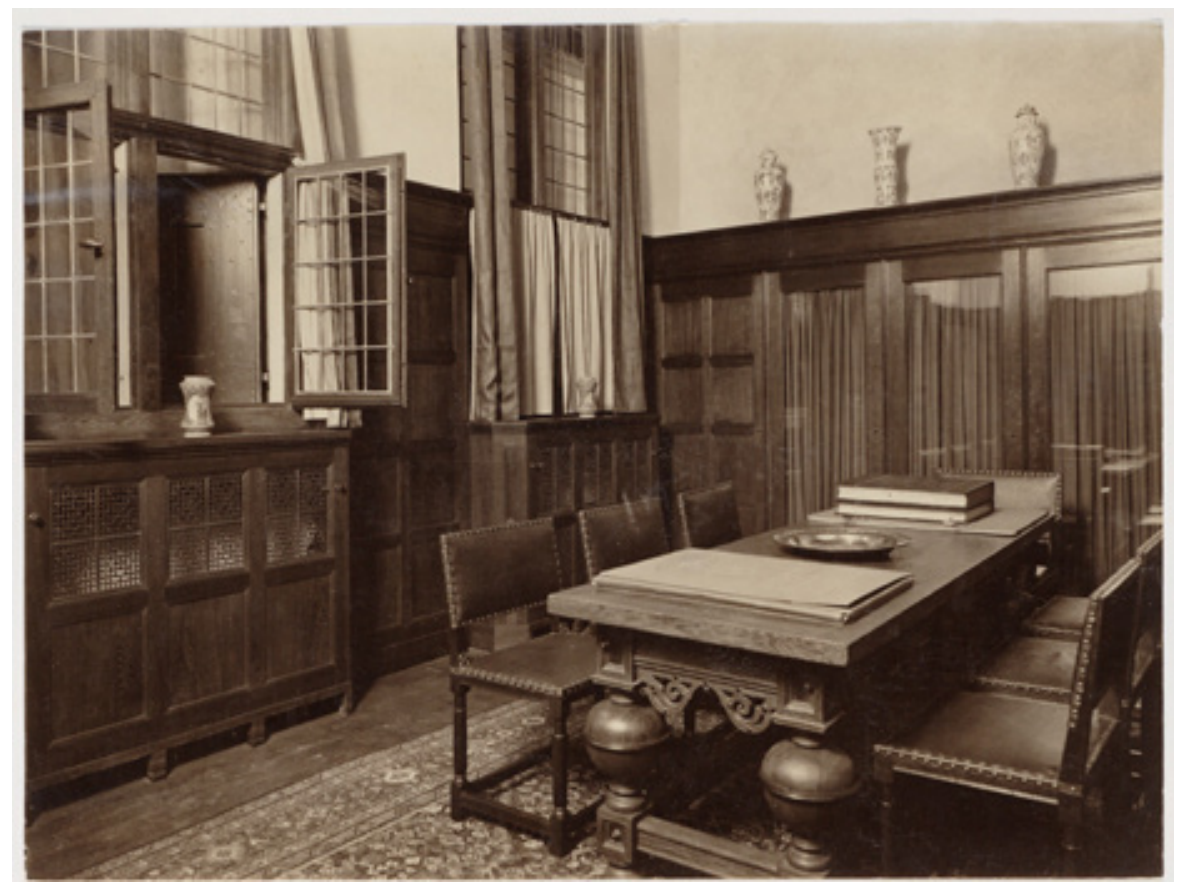

2. Interieur van de Saal in het Rembrandthuis omstreeks 1911, met de aankleding van Karel de Bazel. Stadsarchief Amsterdam.

De Bazels ingreep was van meet af aan controversieel.48 Geheel in lijn met zijn modernistische opvattingen bracht De Bazel weliswaar de voorgevel van het pand terug naar de verondersteld zeventiende-eeuwse staat, maar binnenin vermeed hij zorgvuldig alle zeventiende-eeuwse ornamentiek. Sobere eikenhouten lambriseringen bedekten er de muren in plaats van overdadig leerbehang (afb. 2). Het stichtingsbestuur zag zich dan ook gedwongen te reageren op de soms felle kritiek als zou de voorwaarde die de gemeente bij de overdracht aan de Stichting had gesteld niet zijn gerespecteerd. In de eerste bezoekersgids van het in 1911 geopende museum publiceerde kunstschilder Jan Veth (1864-1925), zelf een van de vermaardste

48 Zie voor uitvoerige analyses van De Bazels ingreep D.J. de Vries, 'In de ban van Rembrandt, huizen en herdenkingen', in: Bulletin van de Nederlandse Oudheidkundige Bond, 105.4 (2006), pp.128-130 en Y Brentjens, K.P.C. de Bazel (1869-1923). Ontwerpen voor het interieur, Zwolle \& Den Haag 2006, pp.161-166. 
Rembrandt-kenners van zijn tijd, dan ook namens het bestuur een uitgebreide verantwoording van keuzes die De Bazel had gemaakt:

Van een feitelijk terugbrengen tot den ouden toestand kon geen sprake wezen. Trouwens wat zou die oude toestand beteekenen, buiten de vroegere, levendige bestemming? ... Zelfs aan de hand van den uitvoerigen inventaris van Rembrandt's boedel, uit het jaar 1656, en gesteund door het meest nauwgezette, archeologische onderzoek van het gebouw, is wel in hoofdzaken maar geenszins tot in alle onderdeelen duidelijk mogen worden, hoe het huis door Rembrandt bewoond werd. En wat den prachtigen inboedel betreft, die hij er in had samengebracht, daarvan is geen enkel stuk terug te krijgen, en het blijft zelfs vaak onzeker, wat het eigenlijk was wat hij bezat. Hetgeen men door geforceerd terugbrengen tot den vroegeren toestand bereikt zou hebben, zou dus toch nooit meer dan een verbeeldings-maskerade zijn geworden: een quasi-historisch document dat inderdaad een vervalsching was. En het eenige, waarnaar men zou zoeken, iets van Rembrandt's eigen geest, ware zeker verre gebleven. ${ }^{49}$

Daarmee was nog niet de vraag beantwoord wat te tonen in het nieuwe museum. Van de overdracht van enkele Rembrandtsmeesterwerken uit andere collecties kon uiteraard geen sprake zijn. Daarom besloot het stichtingsbestuur zich toe te leggen op de verzameling van etsen en tekeningen van de grote kunstenaar en daartoe ook zijn donateurs aan te spreken. Ondanks die eerder smalle collectie, een beperking waar het bestuur zich overigens goed bewust van was, trok het museum al snel na de opening in 1911 een groot publiek. ${ }^{50}$

\section{Een Antwerpse pastiche}

Enkele maanden nadat de Stichting Rembrandthuis met de steun van de gemeente Amsterdam het Rembrandthuis had verworven, waagde het Antwerpse stadsbestuur op zijn beurt in 1908 een nieuwe poging het Rubenshuis te kopen. Maar nadat het weerom had gefaald, besloot het de zaak over een andere boeg te gooien. Zo de stad

49 Korte gids voor het Rembrandthuis, Amsterdam (Stichting Rembrandt-huis), s.d. (1911), pp.4-10.

$50 \quad$ F. Tissink, Het Rembrandthuis, Houten 2014, p.22. 
het Rubenshuis niet in handen kreeg, moest zij maar een kopie laten vervaardigen. Die replica op ware grootte, gemaakt van gips en bordkarton fungeerde als Antwerps paviljoen tijdens de Brusselse wereldtentoonstelling van 1910. Deze reconstructie was het werk van stadsarchitect Henri Blomme (1845-1923). ${ }^{51}$ Critici hebben haar later afgedaan als een neobarokke pastiche. ${ }^{52}$ Welbeschouwd is dat een curieus verwijt, alsof Blomme die zich in al zijn werk een historiserend bouwmeester toonde iets anders had kunnen optrekken. Destijds oogstte zijn reconstructie dan ook grote lof. Talloze bezoekers meenden werkelijk dat zij Rubens' huiskamer waren binnengestapt en er zijn wandtapijten hadden bewonderd. ${ }^{53}$ Een luxueus uitgevoerd platenalbum met Blommes bouwtekeningen, gravures en foto's sterkte hen in die illusie. ${ }^{54}$ Ook Max Rooses' gelegenheidsbrochure Het huis van Rubens, eigenlijk de vertaling van een artikel dat hij vijfentwintig jaar eerder in het Frans had laten verschijnen, vond gretig aftrek. ${ }^{55}$ De publiciteitsstunt leek te werken. Een comité, waarin onder andere Rooses en Blomme zetelden, onderhandelde met de eigenaars over de overdracht van het Rubenshuis aan de stad. In het voorjaar van 1914 waren beide partijen elkaar dicht genaderd. Maar de Eerste Wereldoorlog gooide roet in het eten. Toen de onderhandelingen in 1919 werden heropend, bleek de vraagprijs te hoog voor het stadsbestuur dat op dat ogenblik andere prioriteiten had.

\section{Het Rembrandthuis als lichtend voorbeeld}

Max Rooses mocht de inrichting van het Rubenshuis als museum niet meer mee maken. Maar hij gaf zijn droom wel door aan zijn jongere vrienden en bewonderaars Paul Buschmann (1877-1924) en Ary Delen (1883-1960). Buschmann was een telg uit een vooraanstaand Antwerps drukkersgeslacht. Onder zijn impuls legde het familiebedrijf

51 Voor een biografische notitie van Henri Blomme zie: A. Van Loo (red.), Repertorium van de architectuur in België van 1830 tot heden, Antwerpen 2003, pp.157-158.

52 Cf. P. Huvenne, 'Het Rubenshuis: van Rubens' huis tot Museum' in: Openbaar Kunstbezit in Vlaanderen, 26.4 (1987-1988), p.129.

53 V. d'Oultremont, L'exposition universelle et internationale de Bruxelles en 1910 (onuitgegeven mémoire de licence), Louvain-la-Neuve 1988, p.95.

54 La Maison de Rubens. Reconstitution par Henri Blomme. Pavillon de la ville d'Anvers à l'exposition universelle de Bruxelles 1910, Antwerpen 1910.

55 Vergelijk M. Rooses, 'La maison de Rubens', in: Bulletin de l'Académie d'Archéologie de Belgique, 25 (1888), pp.305-319 met M. Rooses, Het huis van Rubens, heropgebouwd in de wereldtentoonstelling te Brussel in 1910, Antwerpen 1910. 
zich onder andere toe op bibliofiele uitgaven en op kunstboeken. In 1905 was hij gepromoveerd op een studie naar Rubens' leerling Jacob Jordaens en in 1911 en trouwde hij met Elsa Van Rijswijck, de dochter van burgemeester Jan Van Rijswijck. Na de Eerste Wereldoorlog klom Buschmann op tot hoofdconservator van het Antwerpse Museum voor Schone Kunsten. ${ }^{56}$ Net als Paul Buschmann had Ary Delen aan het Brusselse Institut Supérieur d'Histoire de l'Art et d'Archéologie gestudeerd. ${ }^{57}$ In 1920 werd hij adjunct-conservator van het Plantin-Moretus Museum om in 1935 promotie te maken tot conservator van het stedelijk prentenkabinet. Onmiddellijk na de Bevrijding, in de herfst van 1944, werd hij hoofdconservator van het Museum voor Schone Kunsten, wat hij tot zijn pensionering in 1948 bleef. Buschmann en Delen deelden dus een liefde voor grafiek. Met bewondering keken zij naar wat in het Amsterdamse Rembrandthuis was gerealiseerd en bepleitten zij in tal van lezingen en publicaties, een soortgelijke aanpak in Antwerpen. Net zoals Karel de Bazel alleen de voorgevel van het Rembrandthuis naar zijn zeventiende-eeuwse staat had teruggebracht, zouden in Antwerpen, aldus Buschmann en Delen slechts de authentieke delen van het Rubenshuis, in het bijzonder de portiek en het tuinpaviljoen dienen te worden gerestaureerd. Het pand zelf zou dan een nieuwe bestemming als prentenkabinet en kunsthistorisch studiecentrum kunnen krijgen. ${ }^{58}$

56 A.J.J. Delen, 'In memoriam dr. Paul Buschmann', in: Onze Kunst, 40 (1923-'24), pp.57-64. Voor zijn huwelijk met Elsa Van Rijswijck had Buschmann een langdurige relatie met een zeventien jaar oudere Nederlandse dame. Sylvia Van Peteghem heeft dan ook een uitgebreide biografische schets van Buschmann opgenomen in haar Alida Wynanda Sanders van Loo (1860-1939). De biografie van een vergeten schrijfster, journaliste en vertaalster. Deel 1. Biografie (onuitgeven proefschrift), Gent 1993-'94, pp.48-63.

57 Biografische notities van Ary Delen door A. Goovaerts \& M. Somers, 'Delen, Ary J.J.', in: R. de Schryver e.a. (red.), Nieuwe Encyclopedie van de Vlaamse Beweging. A-F, p.894 en S. van den Bossche, 'De flamboyante verschijning van Ary Delen (1883-1960). Ik heb de pest aan het literatuurtje-spelen van sommige holklinkende vaten', in: Nieuw Letterkundig Magazijn, 22 (2004), pp.2-9.

58 Delens en Buschmanns argumenten zijn vooral terug te vinden in respectievelijk: A.J.J. Delen, Het huis van Pieter Pauwel Rubens. Wat het was. Wat het werd. Wat het worden kan, Brussel 1933, en het oorspronkelijk reeds uit 1914 daterende maar pas vele jaren later gepubliceerde P. Buschmann, 'Over herstelling en bestemming van het huis Rubens', in: Het Huis van Rubens. Periodisch bulletin, nrs. 1-2 (1938), pp.51-8. Voor een uitvoerige analyse van hun argumenten; zie R. Tijs, 'Restauratie', in: Antwerpen in de 20ste eeuw. Van Belle Epoque tot Golden Sixties, Brasschaat 2008, pp.260-266. 


\section{Een harde restauratie}

In de zomer van 1937 verwierf de stad Antwerpen met de hulp van donateurs en na een jarenlange juridische strijd dan toch het Rubenshuis. Eerder al had de gemeenteraad bij motie de toekomstige bestemming van het gebouw vastgelegd: er moest een museum en een prentenkabinet komen. Aanvankelijk hoopte het stadsbestuur de restauratie te kunnen voltooien voor de Rubensfeesten van 1940. Dan zou het immers precies driehonderd jaar geleden zijn dat de kunstenaar overleed.

Om die restauratie in goede banen te leiden, richtte burgemeester Camille Huysmans (1871-1968) in het voorjaar van 1938 een begeleidingscommissie op. ${ }^{59}$ Huysmans, die van 1925 tot en met 1927 minister van Kunsten en Wetenschappen was geweest, vond dit project erg belangrijk en zat de commissie aanvankelijk persoonlijk voor (afb. 3). Ook later zou hij van nabij bij het project betrokken blijven en zijn visie laten gelden. ${ }^{60}$ Verder maakten onder andere criticus Ary Delen en stadsarchitect Emiel Van Averbeke (1876-1946) deel uit van die commissie. Eertijds had Van Averbeke naam gemaakt als een eclectisch art nouveau architect, maar tijdens de jaren '2o en '3o combineerde hij modernistische ontwerpen zoals die voor het Torengebouw (beter bekend als de Boerentoren) (1929-'31) en de monumentale poortgebouwen van de voetgangerstunnel onder de Schelde (1931-'33) met ingrijpende restauraties, zoals die van de toren van de Onze-Lieve-Vrouwekathedraal (1926-'30). ${ }^{61}$

In de schoot van de commissie leefden zeer verschillende opvattingen over de manier waarop de restauratie moest worden aangepakt. ${ }^{62}$ Anders dan de nostalgici die nog steeds het model dat Blomme in 1910 had laten vervaardigen voor ogen stond, kwam eenmaal de buitenmuren van het huis waren vrijgemaakt en het binnenin was

59 De veelzijdige loopbaan van Huysmans is uitvoerig geboekstaafd in J. Hunin, Het enfant terrible Camille Huysmans, 1871-1968, Amsterdam 1999.

60 T. Van Driessche, 'Teneinde de historische werkelijkheid op een zo volmaakt mogelijke wijze te benaderen. Emiel Van Averbeke en de herschepping van het Rubenshuis', in: $M \mho L$. Monumenten, Landschappen en Archeologie 32.2 (2013), pp.12-43 biedt een nauwgezette reconstructie en analyse van het restauratieproces. Voor de rol van burgemeester Huysmans, zie aldaar i.h.b. pp.36-37.

61 Zie voor een biografische notitie van Van Averbeke: A. Van Loo (red.), Repertorium, pp.548-549.

62 Onder impuls van burgemeester Huysmans verschenen in 1938 twee nummers van het als tijdschrift bedoelde Het Huis van P.P. Rubens. Periodisch bulletin. In verschillende artikelen zetten Van Averbeke en Delen hun standpunten uiteen. Ook publiceerde deze laatste daarin de eerder onuitgegeven notities van zijn overleden vriend Buschmann, cf. noot 56 . 
gestript, de kunstenaar Rubens immers niet als een Deux ex machina onder de ruïnes vandaan. Daarmee leek de hele onderneming in een impasse beland.

Als direct verantwoordelijke voor de restauratie nam Van Averbeke vervolgens het initiatief. Hij kon dat doen omdat hij het volste vertrouwen van burgemeester Huysmans genoot. Maar Van Averbeke wilde tevens zijn critici voor zich winnen. In 1941 zette hij in een brochure zijn restauratieopvattingen omstandig uiteen. ${ }^{63}$ Daar kwam ook wel eens een gelegenheidsargument aan te pas. Weliswaar gaf Van Averbeke toe dat de zuiden westgevels van de binnenplaats oorspronkelijk waren beschilderd met fresco's. Maar hij koos voor half verheven beeldhouwwerk. Immers, 'in 1640, bij zijn [= Rubens] overlijden, was het bouwwerk ... niet voleind.' Met andere woorden: mocht de schilder tijd van leven hebben gehad, zou hij zeker voor Van Averbekes definitieve oplossing hebben ge-

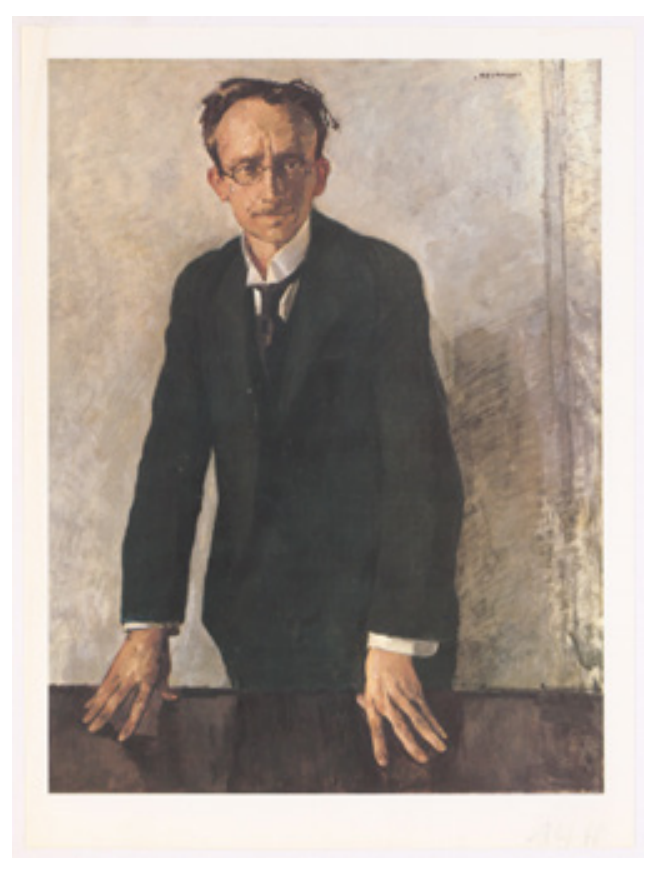

3. Portret uit 1928 van Camille Huysmans door Isidoor Opsomer. Koninklijk Museum voor Schone Kunsten Antwerpen. kozen. ${ }^{64}$ Weliswaar waren bouwmaterialen tijdens de oorlog schaars, maar verder legden de Duitse bezetters Van Averbeke en zijn team weinig in de weg (afb. 4). Wel integendeel het aantal werknemers op de werf liep voortdurend op. In 1937 waren het er niet meer dan een tiental, maar tegen de zomer van 1944 was hun aantal aangegroeid tot een vijftigtal. Op die manier ontsnapten zij ook aan de verplichte tewerkstelling in Duitsland. Bij de bevrijding, in september 1944, was de ruwbouw vrijwel geheel voltooid.

63 F. Clijmans \& E. Van Averbeke, Rondom den wederopbouw van het Rubenshuis, Antwerpen 1941.

64 Cf. P. Huvenne, 'Het Rubenshuis', pp.130-132. 


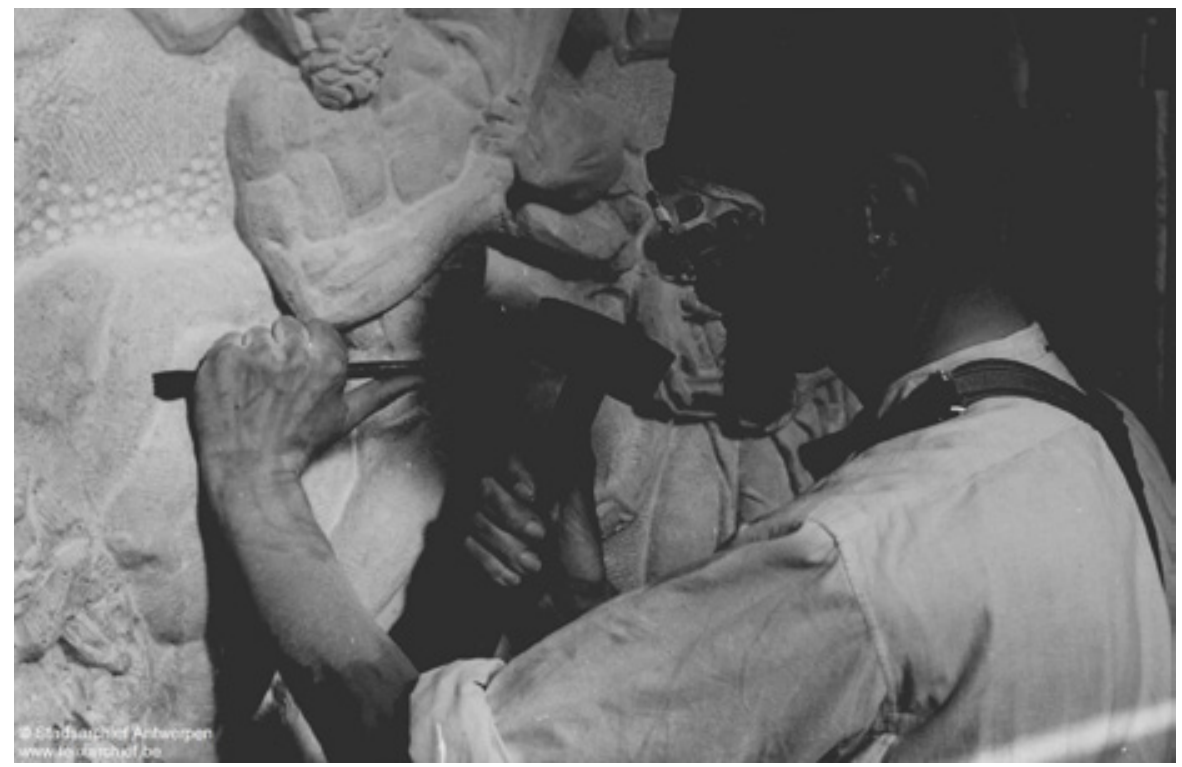

4. Beeldhouwer aan het werk bij de restauratie van het Hermesbeeld in de portiek van het Rubenshuis; 10 mei 1941. Felixarchief Antwerpen.

Ook de inmiddels uit ballingschap in Londen teruggekeerde burgemeester Huysmans en zijn vernieuwde stadsbestuur hechtten nog steeds zeer aan dit prestigeproject. Zo bleven de restauratoren ook tijdens de wintermaanden van 1944-'45, toen bijna negenhonderd V-bommen op de stad insloegen, ongeveer een tiende van de woningvoorraad werd verwoest en bijgevolg het openbare leven in de stad vrijwel geheel stil kwam te liggen, gewoon op hun post. ${ }^{65}$ De 'bomvrije' kelders die ze eerder tijdens de oorlog hadden uitgegraven kwamen nu goed van pas.

Naarmate voltooiing van de werken naderde, kwam een oude vraag weer bovendrijven: wat te tonen in het Rubenshuis? Vooralsnog was het immers een museum zonder collectie en op korte termijn een verzameling uitbouwen was natuurlijk ook hier uitgesloten. Bovendien voelde burgemeester Huysmans daar weinig voor. Volgens

65 P. Serrien, Elke dag angst. De terreur van de V-bommen op België (1944-1945), Amsterdam 2017. 
hem dienden bezoekers daar allereerst een 'bewogen periode uit de nationale geschiedenis te kunnen herbeleven'. ${ }^{66}$ Het museum werd aanvankelijk dan ook vooral gestoffeerd met vroegmoderne meubels en gebruiksvoorwerpen. Op die manier kregen de bezoekers een idee van de woonomgeving, levensstijl en werkmethoden van een welstellende, geleerde zeventiende-eeuwse kunstenaar en diplomaat.

\section{Een succesvol museum}

Die formule bleek uiterst succesvol. De illusie als zou het palazzo er opnieuw uit zien als in de jaren dat de schilder er had gewoond en gewerkt trok bij de opening in het voorjaar van 1947 een menigte bezoekers aan. In de daaropvolgende decennia groeide hun aantal gestaag van 50 à 60.000 per jaar in de jaren 1950 tot net geen 200.000 in 2015.67

Dat succes maakte dat het Rubenshuis meteen een eigen plaats in het Antwerpse museumlandschap verwierf en steeds meer vrienden en donateurs aantrok. Dankzij hun steun en die van de stedelijke overheid slaagden de opeenvolgende conservatoren erin aansprekende tentoonstellingen te organiseren, meer langdurige bruiklenen te verwerven en een fraaie eigen collectie op te bouwen. Geheel voor de hand liggend kozen zij daarbij in eerste instantie voor stukken van Rubens zelf en van diens leerlingen en tijdgenoten. Op die manier biedt het museum de bezoekers tegenwoordig niet alleen de suggestie van hoe een zeventiende-eeuwse patriciërswoning eruit zou kunnen hebben gezien. Dankzij de vele schetsen, studies en werken van Rubens' leerlingen die het museum de afgelopen decennia verwierf, ontdekken zij er tegenwoordig bovenal hoe zijn 'bedrijf' werkte. Een belangrijke katalysator van deze ontwikkeling was de oprichting van het Rubenianum in 1963. Dit documentatiecentrum, dat sinds 1981 in het achter het Rubenshuis gelegen Kolveniershof huist, groeide de afgelopen decennia uit tot een toonaangevend kennisinstituut over vroegmoderne kunst uit de Zuidelijke Nederlanden. Op die manier werd de oude droom van Paul Buschmann en

66 Mijn vertaling van Huysmans' citaat in een tijdschriftartikel uit het najaar van 1945: 'Elle (= la maison de Rubens) permettra au visiteur de revivre par l'esprit et par le coeur une époque mouvementée de notre histoire nationale,' zoals weergegven in Van Driessche, 'Teneinde de historische werkelijkheid', p.37.

67 De jongste beschikbare cijfers slaan op 2015. Cf. https://www.allesoverantwerpen.nl/ antwerpen/statistieken-en-cijfers.html (geraadpleegd 12 september 202O). 
Ary Delen, die trouwens in 1940 het begrip Rubenianum voor het eerst naar voren had geschoven, alsnog gerealiseerd. ${ }^{68}$

\section{Intussen in Amsterdam}

Hoewel het Amsterdamse Rembrandthuis soberder was opgezet dan het Antwerpse Rubenshuis, en het met zijn collectie die lange tijd voornamelijk uit tekeningen en gravures had bestaan in de schaduw van het Rijksmuseum bleef, was het gemiddeld bezoekersaantal per jaar ook daar in de eerste helft van de jaren 1990 tot ongeveer 125.00o per jaar toegenomen. ${ }^{69}$ Daar was het pand niet op berekend. Bovendien konden in de krappe ruimtes nauwelijks tentoonstellingen worden georganiseerd. Verdere groei was dus uitgesloten. Een ingenieus plan dat het toenmalig Stichtingsbestuur tussen 1995 en 1999 met steun van de gemeente Amsterdam realiseerde, moest de toekomst van het museum waarborgen. Eerst werd de gevel van het naastgelegen Saskiahuis, een voormalige en intussen vervallen negentiende-eeuwse textielfabriek, 7,5 meter opgeschoven. Vervolgens kwam op de vrijgekomen kavel een nieuw pand te staan, waarin de collectie etsen en tekeningen, een auditorium, sanitair en ontvangstruimtes werden ondergebracht. Als om het contrast met het oude Rembrandthuis te beklemtonen, kreeg dat nieuwe pand een spectaculaire, futuristisch aandoende voorgevel van Moshé Zwarts (1937-2019) ${ }^{70}$ en Rein Jansma (1959-). ${ }^{71}$ Vervolgens werd in het oude pand, onder andere onder verwijzing naar het Antwerpse voorbeeld, de aankleding van De Bazel verwijderd. In de plaats daarvan reconstrueerde een team van onderzoekers en restauratoren onder aanvoering van Bob van den Boogert (1958-2015) ${ }^{72}$

68 P. Huvenne, Het Rubenshuis. Antwerpen, Brussel 1990, p.119. Cf. https://www.rubenianum.be/nl/pagina/historiek (geraadpleegd 12 september 2020).

69 NRC Handelsblad, 25 juli 1994, p.6.

70 Zie voor een overzicht van Zwarts werk en zijn belang voor de Nederlandse architectuur: https://architectenweb.nl/nieuws/artikel.aspx?ID=46951 (geraadpleegd 13 september 2020).

71 Een korte schets van Jansma's parcours is te vinden op de website van het Amsterdams architectuurinstituut: https://www.arcam.nl/rein-jansma/ (geraadpleegd 13 september 2020).

72 R. Nachbahr, 'Bob Cornelis van den Boogert', in: Jaarboek van de Maatschappij der Nederlandse Letterkunde, 2016, pp.55-63. 
en Henk Zantkuijl (1925-2012) ${ }^{73}$ de indeling en inrichting van het huis zoals het er aan de vooravond van Rembrandts faillissement in 1656 had uitgezien. ${ }^{74}$

Vooral deze laatste ingreep riep felle reacties op. Omdat nu eenmaal niet meer te achterhalen viel hoe het Rembrandthuis er eertijds precies had uitgezien en de toenmalige inboedel goeddeels verdwenen was, meenden tegenstanders dat deze reconstructie niets anders dan een vervalsing kon opleveren. Op die manier zou het Rembrandthuis zijn toekomstige bezoekers slechts een illusie bieden. ${ }^{75}$ Bovendien was en is het pand een beschermd monument. Die bescherming sloeg, aldus deze tegenstanders, niet alleen op de buitenzijde, maar ook op het eertijds door De Bazel ontworpen interieur dat intussen cultuurhistorische waarde had verworven. Het Cuypersgenootschap meende zelfs dat hier de restauratie-ethiek werd geschonden en legde de kwestie voor aan de rechter. Die stelde het bestuur van de Stichting Rembrandthuis in het gelijk. Ondanks de gerezen commotie zette dat dan ook zijn plannen onverkort door. De toenmalige museumdirecteur Ed de Heer meende op deze manier 'juist in een tijd waarin het historisch besef in grote delen van de samenleving lijkt te verdwijnen ... de band met ons verleden op evocatieve wijze levend (te) kunnen houden. ${ }^{76}$

Die stelling is illustratief. Museumbezoek werd zo een ervaring, een 'belevenis' waarbij contact met de kunstenaar en zijn tijdgenoten veeleer dan appreciatie voor diens werken centraal staat. Voortbouwend op dat elan wil het Rembrandthuis in zijn tentoonstellingsbeleid actuele thema's aansnijden en zijn collectie vaker confronteren met hedendaagse kunst. ${ }^{77}$ Een voorbeeld van die ambitie is de tentoonstelling Zwart in Rembrandts tijd die in het voorjaar en de zomer van 2020 liep. ${ }^{78}$ Die aanpak werkt. Sinds de millenniumwisseling sprongen de bezoekersaantallen omhoog, tot december 2012). Ook raadpleegbaar op internet als: https://www.amsterdamsebinnenstad.nl/nieuws/zantkuijl.html (geraadpleegd 14 september 202O).

74 H.J. Zantkuijl zette zijn restauratie-opvattingen omstandig uiteen in zijn artikel 'Het huis waar Rembrandt woonde', in: Kroniek van het Rembrandthuis, 51.1/2 (1997), pp.15-37.

75 Cf. B. Laan, 'Het interieur van het Rembrandthuis. Ontwerp voor een levende bestemming', in: Amstelodamum. Maandblad voor de kennis van Amsterdam, 85.3 (1998), pp.73-80. Zie ook J. Koelemeijer, 'Een kijkhuis vol valse meubels. Het Rembrandthuis wordt net echt zeventiende-eeuws', in: De Volkskrant, 20 februari 1998.

76 E. de Heer, 'Voorwoord', in: F. Tissink, Museum het Rembrandthuis, 2003, p.5.

77 K. Keijer, 'Het Rembrandthuis toont straks ook het hier en nu', in: Het Parool, 9 juni 2019.

78 E. Kolfin \& E. Runia eds., Zwart in Rembrandts tijd, Zwolle \& Amsterdam 2020. 
een gemiddelde van circa 220.000 per jaar en zelfs uitschieters van ongeveer 290.000 bezoekers in de Rembrandtjaren 2006 en 2019. ${ }^{79}$ Die groei in het aantal bezoekers is voor een Museum als het Rembrandthuis dat voor ongeveer twee derde van zijn inkomsten afhankelijk is van entreegelden en van de bestedingen van de bezoekers in de museumwinkel een wissel op de toekomst. ${ }^{80}$ Tegelijkertijd voldoet de huidige opzet van het museum niet langer om die gestage bezoekersstroom in goede banen te leiden. Na kleine verbouwingen in 2018 staat voor de komende jaren alweer een grootschalige uitbreiding op het programma. ${ }^{81} \mathrm{Al}$ blijft het vooralsnog een open vraag of die plannen na afloop van de coronacrisis overeind zullen blijven.

Minder fortuinlijk dan het Rembrandthuis zelf verging het De Bazels eikenhouten lambriseringen en de meubels die hij speciaal voor het museum had ontworpen. Nadat ze uit hun oorspronkelijke omgeving waren verwijderd, werden zij opgeslagen in containers en afgevoerd naar een industrieterrein. Daar stonden zij vervolgens enkele jaren te verkommeren. Aanvankelijk zouden zij dienst doen als reserve-onderdelen voor De Bazels hoofdkantoor van de Nederlandsche Handel-Maatschappij aan de Amsterdamse Vijzelgracht. Maar toen de ABN Amro dat aan de gemeente Amsterdam verkocht, die er in 2007 zoals hierboven reeds gememoreerd het stadsarchief in vestigde, verloren ze iedere bestemming. De stukken dreigden te worden vernield of in de onderdelen op de markt te worden gebracht. Uiteindelijk kwamen ze in 2004 terecht bij het Rijksmuseum Twenthe. ${ }^{82}$ Daar berusten zij voorlopig in het depot. Plannen om er een van de drie fabrikantenvilla's die De Bazel in de jaren 1910 in Enschede ontwierp, mee te bekleden, gingen vooralsnog niet door.

\section{Een Rubens experience in Antwerpen?}

Ook in Antwerpen was het Rubenshuis omstreeks de millenniumwisseling dringend aan uitbreiding toe. Daartoe ontwierpen Stéphane Beel (1955-) en Maur Dessauvage

79 C. Kammer, 'Aanvaringen komen in de beste kringen voor', in: NRC Handelsblad, 28 januari 2009 en Stichting Museum Het Rembrandthuis. Jaarverslag 2018, Amsterdam 2019, p.4. Dit jaarverslag is het jongste dat beschikbaar is bij het schrijven van dit artikel.

80 Stichting Museum Het Rembrandthuis. Jaarverslag 2018, pp.48-49.

$81 \quad$ Ibid., pp.15-19 en 38.

82 T. Geerts, 'Gesignaleerd', in: Nieuwsbrief. Stichting het Nederlandse Interieur, nr. 9 (oktober 2004), p.7. 
(1963-) in 1999 tegenover de kunstenaarswoning een glazen onthaalpaviljoen dat zij precies op de rooilijn van de straat, die daar tot 1977 liep, plaatsten. ${ }^{83}$ Omdat hun paviljoen ook net zo breed als het Rubenshuis is en het er als een doorzichtige, goeddeels glazen constructie tegelijkertijd mee contrasteert, kan de bezoeker zich een idee vormen van het vroegere aanzicht van het Rubenshuis. Maar naar de smaak van de Antwerpse stadsbestuurders oogt Beels en Dessauvages ietwat minimalistische paviljoen intussen toch wat al te ingetogen. De komende jaren moet er op het aanpalende Hopland, een dure winkelstraat, een heus 'belevingscentrum' of 'Rubens Experience Center' komen. Afgaand op de plannen wordt dat in 2024 voltooid. ${ }^{84} \mathrm{Net}$ als in Amsterdam zoekt het Antwerpse museum dus nadrukkelijk een nieuw publiek. Zo prijkte tijdens de zomer van 2017 het hoofd van popicoon David Bowie op een affiche aan de ticketbalie van het Rubenshuis. Het museum had toen net Tintoretto's Heilige Catharina, het enige vroegmoderne meesterwerk uit Bowies nalatenschap, in langdurige bruikleen verworven. Daarmee had Bowie niet alleen van Tintoretto een hippe schilder gemaakt, maar van het Rubenshuis ook een hip museum. ${ }^{85}$

\section{Tot besluit}

Van oudsher dichten de inwoners van Amsterdam en Antwerpen hun vaderstad de status van een culturele en economische metropolis toe. Bovendien zijn de geschiedenissen van beide steden nauw met elkaar verknoopt en dus rivaliseren zij met elkaar. De plotse en intense economische, demografische en culturele bloei die zich na een periode van langdurig verval in de tweede helft van de negentiende eeuw zowel in Amsterdam als in Antwerpen voordeed, riep in beide steden het verlangen naar een eerdere bloeiperiode op waaraan men zich kon spiegelen. Beeldbepalende kun-

83 Meer over Stéphane Beel als een architect van museumsites met verwijzing naar zijn ingreep in Antwerpen bij M. Liefooghe, 'Interventies in ons koloniaal paleis. Vijf bedenkingen bij de architectuur van het AfricaMuseum', in: De Witte Raaf, nr. 198 (maart-april 2019), pp.20-21. Een biografische notitie van Beel is te vinden in A. Van Loo, Repertorium, pp.145-146.

84 Deze plannen worden toegelicht op de website van het Rubenshuis, cf. https://www. rubenshuis.be/nl/pagina/masterplan-rubenssite-nieuwbouw-hopland-schetsontwerp (geraadpleegd 14 september 202O).

85 K. Van Boxem, 'Hoe Bowie van Tintoretto weer een hippe schilder maakt', in: De Tijd, 26 juni 2017 (met een interview van Ben Van Beneden, de directeur van het Rubenshuis). 
stenaars als Rembrandt en Rubens fungeerden daarbij als partes pro toto. Zo ontstond voor hen een cultus waartoe dat verlangen zich verdichtte. Zowel in Amsterdam als in Antwerpen werd in de laatste decennia van de negentiende eeuw een groots, nationaal museum gebouwd waarin aan deze lokale helden ereplaatsen werden toegekend. Vervolgens transformeerden beleids- en cultuurmakers de woonhuizen van die helden, Rembrandt en Rubens, tot lieux de mémoire. Die transformatie riep nieuwe vragen op: vereerden en bestudeerden de bezoekers van die huizen grote kunstenaars of herbeleefden zij veeleer de tijd waarin hun helden hadden geleefd? Aanvankelijk haalden in Amsterdam de 'wetenschappers' het van de 'romantici'. Bij de opening in 1911 had het Rembrandthuis meer weg van een studiecentrum dan van het huis waar Rembrandt eens zijn Saskia had lief gehad en waar hij zijn leerlingen had opgeleid. In Antwerpen daarentegen, wilde burgemeester Huysmans, ondanks het protest van leden van het culturele establishment als Paul Buschmann en Ary Delen, zijn tijdgenoten nadrukkelijk bij de hand nemen om hen naar de eerste decennia van de zeventiende eeuw terug te voeren. Toch hielden cultuurmakers in beide steden een oog op wat er in de andere stad gebeurde. Zo groeiden de inrichting van het Rubenshuis en het Rembrandthuis in de tweede helft van de twintigste eeuw naar elkaar toe. Beide kunstenaarshuizen werden echte musea. In de jongste twee decennia zochten en vonden zij, surfend op de golven van het massatoerisme en ook wel onder politieke druk, een ruimer en bovenal ook jonger publiek. Museumdirecties, conservatoren en scenografen wacht de uitdaging te bedenken welke verhalen zij aan dit nieuwe publiek precies wensen te vertellen.

Hans Cools is als hoofddocent werkzaam bij de Onderzoeksgroep Geschiedenis van de Nieuwe Tijd van de KU Leuven. In zijn onderwijs en onderzoek legt hij zich toe op de politieke en sociale geschiedenis van de vroegmoderne Lage Landen, Frankrijk en Italië. Daarnaast heeft hij bijzondere belangstelling voor de plaats van de vroegmoderne periode in de hedendaagse historische cultuur. 
Dit eBook is voorzien van een watermerk met identificatiescode :

BkVcE1JDVARXNIU8VGYANAo2Ay9bMAtqUGhSJgUvAnRXdwwhVyMDLFQi $5 f b b d c c 76 b a 79$

Het eBook is voorzien van een watermerk.

Alle rechten voorbehouden. Niets uit deze uitgave mag worden verveelvoudigd of openbaar gemaakt, in enige vorm of op enige wijze, hetzij electronisch, mechanisch, door kopieen of fotokopieen, opnamen, of op enig andere manier, zonder voorafgaande schriftelijke toestemming van de uitgever. 